ORP-56323

Revision 0

\title{
Final Report - LAW Envelope C Glass Formulation Testing to Increase Waste Loading, VSL-05R5900-1
}

Prepared for the U.S. Department of Energy

Assistant Secretary for Environmental Management

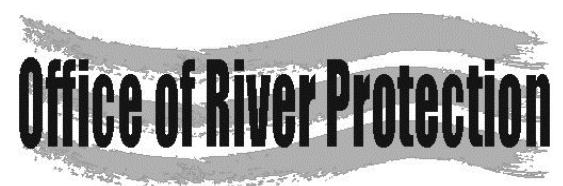

P.O. Box 450

Richland, Washington 99352 
ORP-56323

Revision 0

\section{Final Report - LAW Envelope C Glass Formulation Testing to Increase Waste Loading, VSL-05R5900-1}

A. A. Kruger

Department of Energy - Office of River Protection

I. L. Pegg

The Catholic University of America

K. S. Matlack

The Catholic University of America
I. Joseph

The Catholic University of America

I. S. Muller

The Catholic University of America

W. Gong

The Catholic University of America

Date Published

January 2006

Prepared for the U.S. Department of Energy

Assistant Secretary for Environmental Management

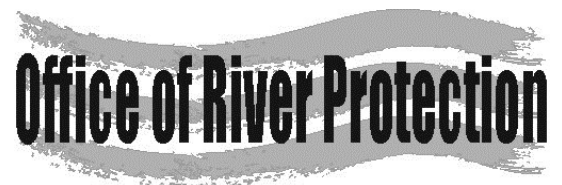

P.O. Box 450

Richland, Washington 99352

APPROVED

By Julia Raymer at 7:15 am, Dec 03, 2013

Release Approval

Date 
ORP-56323

Revision 0

TRADEMARK DISCLAIMER

Reference herein to any specific commercial product, process, or service by tradename, trademark, manufacturer, or otherwise, does not necessarily constitute or imply its endorsement, recommendation, or favoring by the United States Government or any agency thereof or its contractors or subcontractors.

This report has been reproduced from the best available copy.

Printed in the United States of America 
VSL-05R5900-1

\title{
Final Report
}

\section{LAW Envelope C Glass Formulation Testing to Increase Waste Loading}

\author{
prepared by
}

Keith S. Matlack, Weiliang Gong, Isabelle S. Muller, Innocent Joseph, and Ian L. Pegg

\author{
Vitreous State Laboratory \\ The Catholic University of America \\ Washington, DC 20064 \\ for \\ Duratek, Inc. \\ and \\ Department of Energy \\ Office of River Protection
}

August 29, 2005

Rev. 0; 1/27/06 
The Catholic University of America Vitreous State Laboratory
LAW Envelope C Glass Formulation Testing

to Increase Waste Loading

Final Report, VSL-05R5900-1, Rev. 0
Document Title:
Document Number and Revision:
Issue Date:
Performing Organization: Vitreous State Laboratory, The Catholic University of America
Test Plan:
LAW Glass Formulation Testing to Increase Waste Loading, VSL-05T5900-1, Rev. 0

This report describes the results of testing specified by the above Test Plan. The work was performed in compliance with the quality assurance requirements specified in the Test Plan. Results required by the Test Plan are reported. The test results and this report have been reviewed for correctness, technical adequacy, completeness, and accuracy.

I.L. Pegg: VSL Program Dírector/Principal Investigator

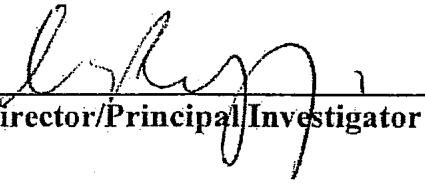

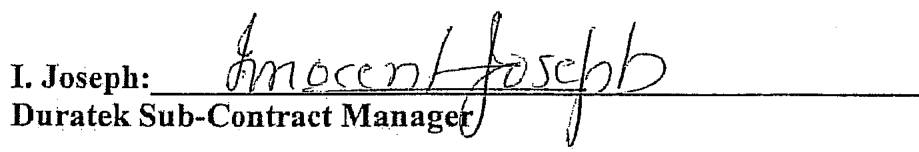

Date:

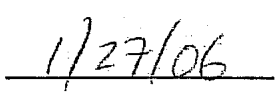

Date: $1-27-06$ 
The Catholic University of America Vitreous State Laboratory
LAW Envelope C Glass Formulation Testing to Increase Waste Loading Final Report, VSL-05R5900-1, Rev. 0

\section{TABLE OF CONTENTS}

LIST OF TABLES. 4

LIST OF FIGURES .5

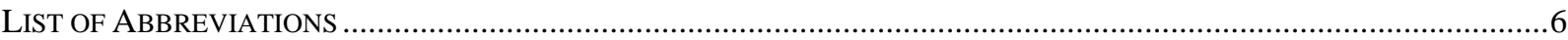

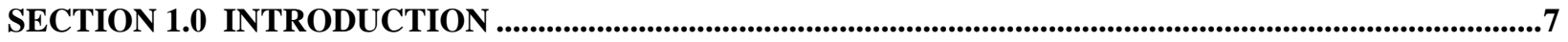

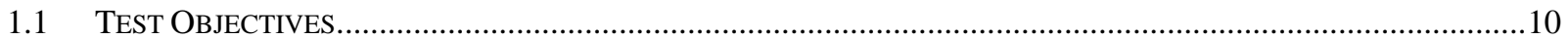

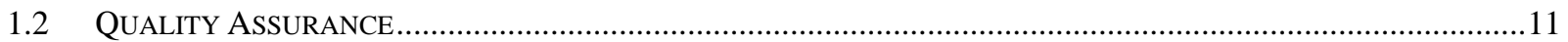

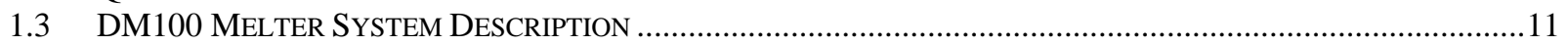

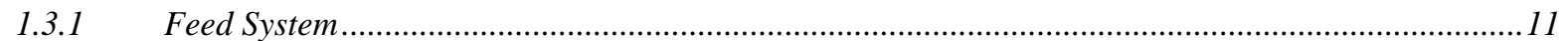

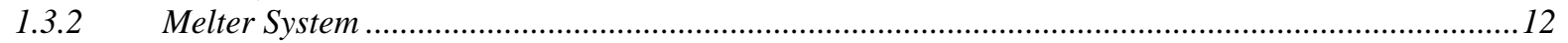

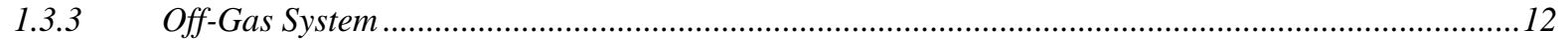

SECTION 2.0 WASTE SIMULANT AND GLASS FORMULATIONS ..........................................................13

\begin{tabular}{|c|c|}
\hline .1 & WASTE SIMULANTS \\
\hline 2.2 & GLASS FORMULATION......... \\
\hline 2.3 & SUGAR ADDITIONS ....................... \\
\hline $.4 \mathrm{~A}$ & 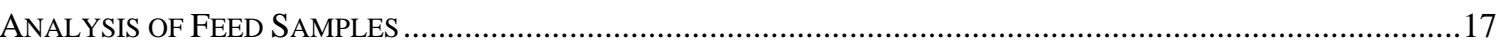 \\
\hline 2.4 .1 & $1 \quad$ General Properties \\
\hline 2.4 .2 & Rheology ......................................... \\
\hline 2.4 .3 & Chemical Composition ..... \\
\hline
\end{tabular}

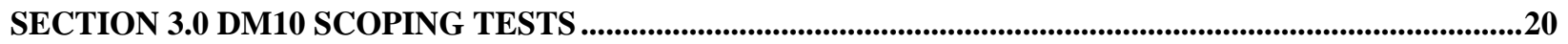

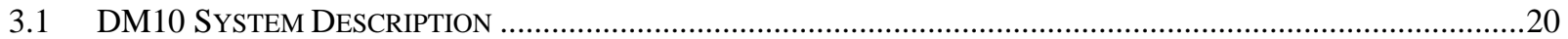

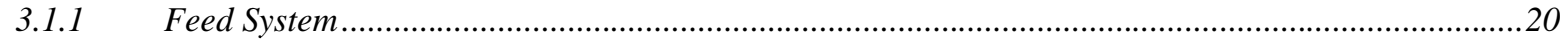

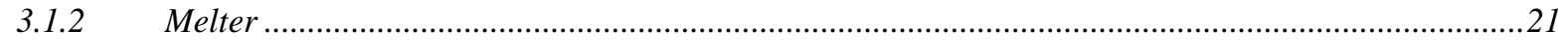

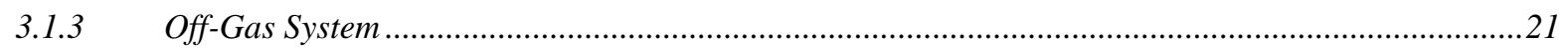

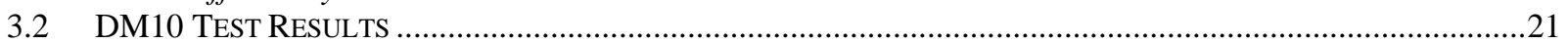

3.3 FEED SUlfur CONCENTRATIONS SELECTED FROM DM10 TESTS ..........................................................22

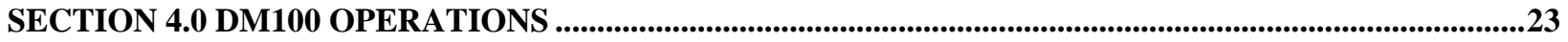

SECTION 5.0 DM100 GLASS PRODUCTS.....................................................................................................27

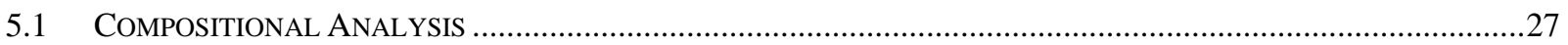

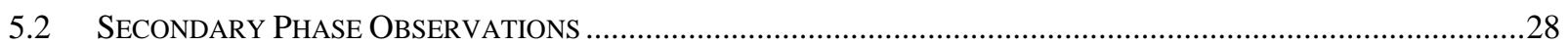

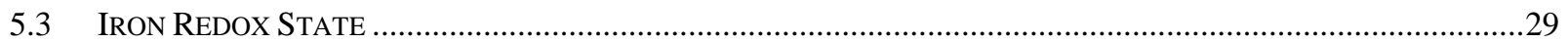

5.4 COMPARISON OF PCT AND VHT OF CRUCIBLE AND MELTER GlasSES .................................................29

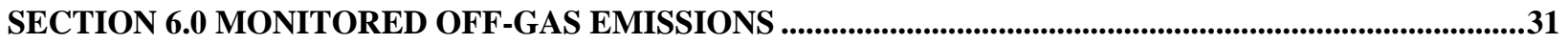

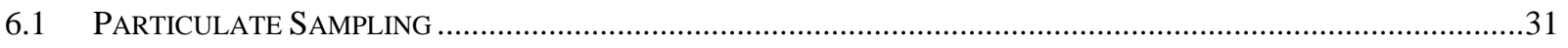

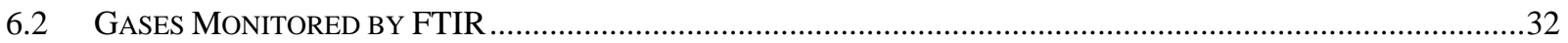

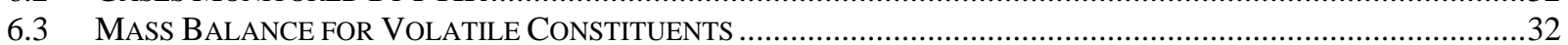

SECTION 7.0 COMPARISON OF TEST RESULS FOR “OLD” AND “NEW” FORMULATIONS FOR

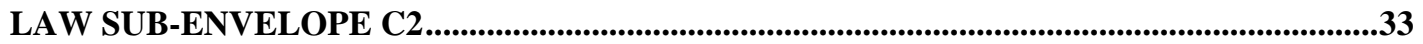

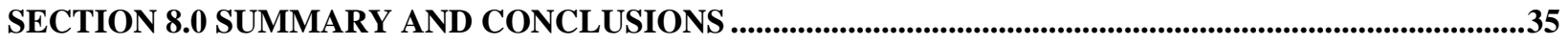

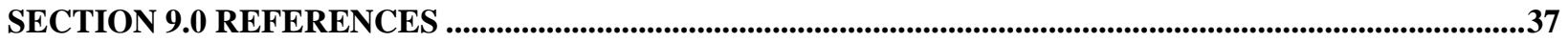


The Catholic University of America

Vitreous State Laboratory
LAW Envelope C Glass Formulation Testing

to Increase Waste Loading

Final Report, VSL-05R5900-1, Rev. 0

\section{List of Tables}

Page No.

Table 2.1. $\quad$ LAW Envelope C (AN-102) Waste Simulant Recipe at 8 Molar Sodium. $\quad$ T-1

Table 2.2. Target and Analyzed Compositions of Four New LAW Envelope C Crucible $\quad$ T-2 Glasses (wt\%).

Table 2.3. $\quad$ Measured Compositions of Four New LAW Envelope C Crucible Glasses $\quad$ T-3

Remelted with 4wt\% Excess $\mathrm{SO}_{3}$ (wt\%).

Table 2.4. Results of 7-day PCT (ASTM C1285-98 at 90 ${ }^{\circ} \mathrm{C}$ ) and VHT (at $200^{\circ} \mathrm{C}$ for $\quad$ T-4

24 Days ( $\mathrm{g} / \mathrm{m}^{2} /$ day)) for Four New LAW Envelope C Glasses.

Table 2.5. Viscosities and Electrical Conductivities of Four New LAW Envelope C T-5

Crucible Glasses.

Table 2.6. Measured Densities and Glass Transition Temperatures (by Differential T-6

Thermal Analysis) of Four New LAW Envelope C Crucible Glasses.

Table 2.7. Results of K-3 Corrosion Testing for Four New LAW Envelope C Crucible $\quad$ T-6

Glasses.

Table 2.8. Summary of Test Results for Selected Glass Formulation LAWC100 and T-7

Comparison to ILAW Requirements.

Table 2.9. Oxide Composition of LAW Envelope C Simulant and Corresponding Glass $\quad$ T-8

Composition Used in Melter Tests (wt\%).

Table 2.10. Glass Former Additives for 1 Liter of LAW Envelope C Simulant (8 M Na) T-9

and Corresponding Melter Feed Properties.

Table 2.11. $\mathrm{NaOH}$ and $\mathrm{Na}_{2} \mathrm{SO}_{4}$ Additions Required to Obtain $20 \mathrm{wt} \% \mathrm{Na}_{2} \mathrm{O}$ and Various $\mathrm{SO}_{3}$ Concentrations in the Glass Ranging from 0.75 to $1.5 \mathrm{wt} \%$.

Table 2.12. Properties of Feed Samples from Crucible Tests and DM10 and DM100 Melter Tests.

Table 2.13. XRF Analyzed Compositions for Melter Feed Samples (wt\%). T-11

Table 3.1. Summary of DM10 Test Conditions and Results. T-12

Table 3.2. $\quad$ Listing of DM10 Glasses Discharged, Masses, and Measured Sulfur Contents. T-14

Table 3.3. Dip samples and Presence of Sulfate Layer during DM10 Melter Tests. T-16

Table 4.1. Summary of DM100 Test Conditions and Results. $\quad$ T-17

Table 4.2. Summary of Measured DM100 Parameters. T-18

Table 5.1. $\quad$ Listing of DM100 Glasses Discharged, Masses, and Analysis Performed. $\quad$ T-20

Table 5.2. $\quad$ XRF Analyzed Composition for DM100 Discharged Glass Samples (wt\%). $\quad$ T-24

Table 5.3. $\quad$ Comparison of XRF and DCP Analysis of Melter Glass Samples (wt\%). $\quad$ T-30

Table 5.4. Dip samples and Presence of Sulfate Layer during DM100 Melter Tests. T-31

Table 5.5. Glass Redox for Selected Glass Samples. T-31

Table 5.6. Results of PCT (ASTM C1285, 7-days at $90^{\circ} \mathrm{C}$ ) and VHT (at $200^{\circ} \mathrm{C}$ for T-32 24 Days ( $\mathrm{g} / \mathrm{m}^{2} /$ day)) for LAW Envelope C Crucible and DM100 Melter Glasses.

Table 6.1. Results from Melter Off-Gas Emission Samples. T-33

Table 6.2. Average Concentration (ppmv) of Selected Species in Off-Gas Measured by $\quad$ T-34 FTIR Spectroscopy during DM100 Tests.

Table 6.3. Concentration Ranges (ppmv) of Selected Species in Off-Gas Measured by $\quad$ T-35 FTIR Spectroscopy during DM100 Tests.

Table 6.4. Average NOx Fluxes in Off-Gas Measured by FTIR Spectroscopy. T-36

Table 6.5. Mass Balance for Sulfur, Iodine, and Chlorine During DM100 Tests with $\quad$ T-37 LAW High Sodium Simulants. (\% of Feed).

Table 7.1 Compositions and Properties of "New" and "Old" LAW C Glasses for AN-102 T-38 
The Catholic University of America

Vitreous State Laboratory
LAW Envelope C Glass Formulation Testing

to Increase Waste Loading

Final Report, VSL-05R5900-1, Rev. 0

\section{List of Figures}

Page No.

Figure 1.1. Schematic diagram of DuraMelter 100-WV vitrification system. F-1

Figure 1.2(a). Cross-section through the DM100-WV melter-Plan View. $\quad$ F-2

Figure 1.2(b). Cross-section through the DM100-WV melter-Section AA. F-3

Figure 1.2(c). Cross-section through the DM100-WV melter-Section CC. F-4

Figure 2.1. Results of $\mathrm{SO}_{2} / \mathrm{O}_{2}$ gas bubbling tests on four new LAW Envelope C F-5 and two old glass compositions at $1150^{\circ} \mathrm{C}$ showing the partial pressure of $\mathrm{SO}_{3}$ vs. the $\mathrm{SO}_{3}$ concentration in the glass melt. The horizontal portions indicate the solubility limits while the slopes at lower concentrations provide measures of the activity coefficient of $\mathrm{SO}_{3}$ in the melt.

Figure 2.2. Measured sulfate solubility by $\mathrm{SO}_{2} / \mathrm{O}_{2}$ gas bubbling, and remelting with excess $\mathrm{SO}_{3}$ for four new LAW Envelope C crucible glasses.

$\begin{array}{lll}\text { Figure 2.3. } & \text { VHT results for four new LAW Envelope C crucible glasses. } & \text { F-7 }\end{array}$

Figure 2.4. Normalized PCT responses for four new LAW Envelope C crucible glasses. F-8

Figure 2.5. K3 Corrosion results for four new LAW Envelope C crucible glasses and three old LAW formulations. $\quad$ F-9

Figure 2.6. Measured viscosity of LAW melter and crucible feed samples. F-10

Figure 2.7. Comparison of measured feed rheology with proposed WTP bounds

(bounds from WTP-RPT-075, Rev. 0, Feb. 2003). $\quad$ F-11

$\begin{array}{lll}\text { Figure 3.1. } & \text { XRF analysis of sulfur in DM10 product glasses. } & \text { F-12 }\end{array}$

Figure 4.1. Glass production rates for the DM100 LAW Envelope C tests. F-13

Figure 4.2. Glass temperatures for the DM100 LAW Envelope C tests. F-14

Figure 4.3. Plenum temperatures and electrode power for the DM100 LAW Envelope

$C$ tests. $\quad$ F-15

Figure 4.4. Electrode temperature and power for the DM100 LAW Envelope C tests. F-16

$\begin{array}{lll}\text { Figure 4.5. } & \text { Glass pool bubbling rate during DM100 LAW Envelope C tests. } & \text { F-17 }\end{array}$

$\begin{array}{lll}\text { Figure 5.1. } & \text { XRF analysis of } \mathrm{Na}_{2} \mathrm{O} \text { and } \mathrm{SiO}_{2} \text { in DM100 product glasses. } & \text { F-18 }\end{array}$

$\begin{array}{lll}\text { Figure 5.2. } & \text { XRF analysis of select major oxides in DM100 product glasses. } & \text { F-19 }\end{array}$

$\begin{array}{lll}\text { Figure 5.3. } & \text { XRF analysis of potassium, vanadium and zinc oxides in DM100 } \\ \text { product glasses. } & \text { F-20 }\end{array}$

Figure 5.4. $\quad$ XRF analysis of chlorine and iodine in DM100 product glasses. $\quad$ F-21

$\begin{array}{lll}\text { Figure 5.5. } & \text { XRF analysis of sulfur in DM100 product glasses. } & \text { F-22 }\end{array}$

Figure 5.6. Secondary phases in discharged glass (WVY-G-121B/C, 1.3 wt. \% $\mathrm{SO}_{3} \quad$ F-23 in feed).

Figure 5.7.a Entire glass discharge from end of tests (WVZ-G-11A, 1.15 wt. \% $\mathrm{SO}_{3}$ in feed, $\mathrm{F}-24$ additional sugar).

Figure 5.7.b Close-up of glass discharge from end of tests showing small sulfate inclusion $\quad$ F-25 (WVZ-G-11A, 1.15 wt. \% $\mathrm{SO}_{3}$ in feed, additional sugar).

Figure 5.8. Sulfate on surface of discharged glass (WVY-G-155B, 1.15 wt. \% $\mathrm{SO}_{3}$ in feed, F-26 additional sugar).

$\begin{array}{lll}\text { Figure 5.9. } & \text { Opaque secondary phases in discharged glass (WVY-G-137B, }\end{array}$

1.15 wt. $\% \mathrm{SO}_{3}$ in feed).

Figure 6.1. Nitrogen oxide concentrations in off-gas from FTIR for the DM100 F-28

LAW Envelope C tests.

Figure 6.2. $\quad$ CO concentrations in off-gas from FTIR for the DM100 LAW Envelope $\quad$ F-29

$\begin{array}{ll}\text { Figure 6.3. } & \mathrm{NH}_{3} \text { concentrations in off-gas from FTIR for the DM100 LAW Envelope } \quad \text { F-30 }\end{array}$ C tests. 


\section{List of Abbreviations}

$\begin{array}{ll}\text { AA } & \text { Atomic Absorption Spectroscopy } \\ \text { ADS } & \text { Air Displacement Slurry } \\ \text { DCP-AES } & \text { Direct Current Plasma Atomic Emission Spectroscopy } \\ \text { DF } & \text { Decontamination Factor } \\ \text { DM } & \text { DuraMelter }{ }^{\circledR} \\ \text { DOE } & \text { Department of Energy } \\ \text { EPA } & \text { Environmental Protection Agency } \\ \text { FTIR } & \text { Fourier Transform Infrared Spectroscopy } \\ \text { GC } & \text { Gas Chromatography } \\ \text { HEPA } & \text { High-Efficiency Particulate Air Filter } \\ \text { HLW } & \text { High Level Waste } \\ \text { IC } & \text { Ion Chromatography } \\ \text { LAW } & \text { Low Activity Waste } \\ \text { M } & \text { Molarity } \\ \text { N } & \text { Normality } \\ \text { ORP } & \text { Office of River Protection } \\ \text { PEG } & \text { Polyethylene Glycol } \\ \text { QA } & \text { Quality Assurance } \\ \text { QAPP } & \text { Quality Assurance Project Plan } \\ \text { QC } & \text { Quality Control } \\ \text { RPP } & \text { River Protection Project } \\ \text { VSL } & \text { Vitreous State Laboratory } \\ \text { WTP } & \text { Waste Treatment and Immobilization Plant } \\ \text { XRF } & \text { X-Ray Fluorescence }\end{array}$




\section{SECTION 1.0 INTRODUCTION}

About 50 million gallons of high-level mixed waste is currently stored in underground tanks at The United States Department of Energy's (DOE's) Hanford site in the State of Washington. The Hanford Tank Waste Treatment Plant (WTP) will provide DOE's Office of River Protection (ORP) with a means of treating this waste by vitrification for subsequent disposal. The tank waste will be separated into low- and high-activity waste fractions, which will then be vitrified respectively into Immobilized Low Activity Waste (ILAW) and Immobilized High Level Waste (IHLW) products. The ILAW product will be disposed in an engineered facility on the Hanford site while the IHLW product will be directed to the national deep geological disposal facility for high-level nuclear waste. The ILAW and IHLW products must meet a variety of requirements with respect to protection of the environment before they can be accepted for disposal.

The Office of River Protection is currently examining options to optimize the Low Activity Waste (LAW) Facility and LAW glass waste form. One option under evaluation is to enhance the waste processing rate of the vitrification plant currently under construction. It is likely that the capacity of the LAW vitrification plant can be increased incrementally by implementation of a variety of low-risk, high-probability changes, either separately or in combination. These changes include:

- Operating at the higher processing rates demonstrated at the LAW pilot melter

- Increasing the glass pool surface area within the existing external melter envelope

- Increasing plant availability

- Increasing the glass waste loading

- Operating the melter at a slightly higher temperature

- Other smaller impact changes

The Vitreous State Laboratory at The Catholic University of America (VSL) and Duratek, Inc. have evaluated several of these potential incremental improvements for ORP in support of its evaluation of WTP LAW facility optimization [1]. Some of these incremental improvements have been tested at VSL including increasing the waste loading, increasing the processing temperature, and increasing the fraction of the sulfur in the feed that is partitioned to the off-gas stream (assuming that the present WTP recycle loop can be broken) [2-4]. These approaches successfully demonstrated increases in glass production rates and significant increases in sulfate incorporation for an LAW Envelope A glass with $20 \mathrm{wt} \% \mathrm{Na}_{2} \mathrm{O}$. The current work focuses on further development and testing of enhanced glass formulations for all of the LAW waste envelopes to increase waste loading in the glass product, which will reduce the amount of glass to be produced by the WTP for the same amount of waste processed. Testing is also designed to determine sulfur retention in the glass product and production rate increases at 
The Catholic University of America Vitreous State Laboratory
LAW Envelope C Glass Formulation Testing

to Increase Waste Loading

Final Report, VSL-05R5900-1, Rev. 0

slightly higher than nominal glass processing temperatures. The results of testing using LAW Envelope C waste simulants and feeds are presented in this report; subsequent reports will present the results from testing with Envelope A and B wastes.

For a large number of Hanford LAW waste streams, sulfur is the main component that limits waste loading in the glasses. For some LAW Envelope A waste streams with low sulfate contents, the alkali concentration becomes the waste loading limiting factor. While processing melter feeds with very high sulfate concentrations, a molten sulfate salt phase forms in the cold-cap region during processing. This phase may exist as transient droplets or can be sufficiently extensive to produce a separate salt phase that becomes mechanically disengaged from the rest of the cold cap. Once formed, the salt phase is slow to dissolve into the underlying glass melt; consequently, the salt phase typically forms before the underlying glass melt is saturated with sulfate [5-8]. If the feed rate is sufficiently low (which is clearly undesirable), the equilibrium sulfate saturation concentration in the glass can be approached more closely before a separate salt phase forms. However, in general, as the feed rate is increased, for the same sulfate concentration in the feed, the salt phase appears progressively earlier. Thus, in practice, the formation of a sulfate phase is governed by both thermodynamic and kinetic factors and, therefore, the effects of both must be considered in order to avoid the formation of such phases during operations.

The presence of the corrosive, low-melting, electrically conductive salt phase is undesirable from the perspectives of melter operation, melter lifetime, safety, and product quality. Accordingly, the WTP plans to control the composition of the LAW melter feed such that formation of a separate salt phase is avoided. Clearly, the control bounds that are imposed will determine the achievable waste loading limits and, therefore, will determine the waste processing rate for a given glass production rate (i.e., melter capacity). A convenient gross metric that has been employed as a planning basis for the WTP is the so-called "rule-of-five", which states that salt phase separation should not be observed for LAW glass waste loadings such that the product of the $\mathrm{Na}_{2} \mathrm{O}$ and $\mathrm{SO}_{3}$ contents (in $\mathrm{wt} \%$ ) in the glass is below five [5]. Clearly, however, the magnitude of this product that is achievable also depends on the concentrations of other components in the glass, as well as other factors. It is recognized, and melter tests have confirmed that, except for the highest sulfate waste streams, which lead to glasses with the lowest sodium concentrations, there is some conservatism in this metric [9-30]. In fact, recent VSL glass formulation development and melter testing for ORP [2] showed sulfate loadings of up to $1.2 \mathrm{wt} \% \mathrm{SO}_{3}$ in a LAW Envelope A glass containing $20 \mathrm{wt} \% \mathrm{Na}_{2} \mathrm{O}$. Based on the results of this recent testing, ORP requested that further testing be performed to demonstrate higher sodium and sulfate loading for all of the LAW waste envelopes. Thus, one of the main objectives of the present glass formulation work is to develop LAW feed and glass formulations that significantly improve upon the rule-of-five-based waste loadings for the LAW Envelopes B and C wastes; a further objective for Envelope A wastes is to investigate sodium oxide loadings above $20 \mathrm{wt} \%$.

Work reported here includes glass formulation development and melter testing to improve waste loadings for LAW Envelope $\mathrm{C}$ waste streams. The work was a direct extension of the work performed previously for LAW Envelope A waste streams [2]. The approach to 
The Catholic University of America Vitreous State Laboratory
LAW Envelope C Glass Formulation Testing

to Increase Waste Loading

Final Report, VSL-05R5900-1, Rev. 0

completing this work included crucible-scale tests to identify glass compositions that lead to increased sulfate solubility and sulfate incorporation rates, screening tests on the DM10 melter, and confirmation tests on the DM100 melter.

The work described in this final report was performed in accordance with the corresponding Test Plan that was prepared for ORP [31], which in turn was prepared in response to an amendment to the LAW Pilot Melter decommissioning and testing letter subcontract [1].

Under a separate contract to support the WTP Project, the VSL is developing and testing glass formulations for RPP-WTP waste envelopes to provide data to meet the RPP-WTP contract requirements and to support system design activities [32-35]. That work is based upon small-scale batch melts ("crucible melts”) using waste simulants. Selected formulations have also been tested in small-scale, continuously-fed, joule-heated melters (DM10 and DM100 systems) [7-18] and, ultimately, in the LAW Pilot Melter [19-30]. Such melter tests provide information on key process factors such as feed processing behavior, dynamic effects during processing, sulfate incorporation, processing rates, off-gas amounts and compositions, foaming control, etc., that cannot be reliably obtained from crucible melts. This sequential scale-up approach in the vitrification testing program ensures that maximum benefit is obtained from the more costly melter tests and that the most effective use is made of those resources.

Under the WTP support effort, VSL and Duratek have developed and identified glass compositions for processing the Phase I LAW tank waste streams for the WTP. These compositions have been tested for processing and product quality requirements at various scales ranging from crucible melts of about $400 \mathrm{~g}$ up to LAW Pilot melter at processing rates in excess of $6600 \mathrm{~kg} /$ day (2000 kg/m²/day). The testing included the nominal feed compositions and those with $\pm 15 \%$ variations in the waste simulants added to the melter feeds. The melter testing provided high confidence that the selected WTP compositions are unlikely to cause accumulation of a separate sulfate phase in the melter even at high feed processing rates. Feed processing characteristics and off-gas characteristics have been determined at various melter scales and data have been collected to support engineering and permitting requirements. Furthermore, statistically designed composition matrices were generated, and crucible melts of these glass compositions were prepared and characterized to qualify the glass composition region covering these LAW glass compositions selected for WTP waste processing. The selected WTP compositions have also been tested to ensure their compatibility with melter materials of construction. The glass formulation development and melter testing work for the selected WTP compositions have reached a level of maturity where the compositions can be used for waste processing at the WTP with relatively high confidence.

The glass formulation and melter testing work presented in this report was aimed at identifying glass compositions that have the potential to accommodate higher waste loadings. This information provides ORP with a basis for evaluation of the likely potential for future enhancements of the WTP over and above the present well-developed baseline. In this regard, the work presented in this report is complementary to, and necessarily of a more exploratory nature than the work performed in support of the current WTP baseline. It should be noted, 
The Catholic University of America

Vitreous State Laboratory
LAW Envelope C Glass Formulation Testing

to Increase Waste Loading

Final Report, VSL-05R5900-1, Rev. 0

therefore, that to the extent that the present effort was successful, considerable further work would be required to bring the level of confidence in the new glass composition regions to a similar level of maturity to that of the current WTP baseline.

The melter tests described in this report utilized blended feed (glass formers plus waste simulant) prepared by Optima Chemicals according to VSL specifications. Sufficient feed was prepared to produce over seventeen hundred kilograms of glass. Reductant in the form of sugar was added to the feed at a stoichiometric ratio of 0.5 ( 1 mole sucrose per 16 mole NOx or 3 mole carbon per 4 mole NOx). The feed was procured from Optima at $\mathrm{Na}_{2} \mathrm{O}$ and $\mathrm{SO}_{3}$ concentrations of $19.42 \mathrm{wt} \%$ and $0.75 \mathrm{wt} \%$ (on a glass basis), respectively; various combinations of $\mathrm{NaOH}$ and $\mathrm{Na}_{2} \mathrm{SO}_{4}$ were then added to the feed at VSL in order to obtain a $\mathrm{Na}_{2} \mathrm{O}$ concentration of $20.00 \mathrm{wt} \%$ and $\mathrm{SO}_{3}$ concentrations in the range of 0.75 to $1.5 \mathrm{wt} \%$ for test segments with progressively higher levels of sulfur. The DM10 was used to determine the processability of the feed and maximum feed $\mathrm{SO}_{3}$ concentrations at melter operating temperatures of $1150^{\circ} \mathrm{C}$, $1175^{\circ} \mathrm{C}$, and $1200^{\circ} \mathrm{C}$. Subsequently, two DM100 tests were conducted, one at $1150^{\circ} \mathrm{C}$ and one at $1175^{\circ} \mathrm{C}$. The starting feed $\mathrm{SO}_{3}$ concentrations for the DM100 tests were based on the results of DM10 melter tests. The DM100-WV melter was used in order to provide a direct comparison with the LAW tests previously conducted on the same melter [2-4, 7-18]. The bubbling rate was adjusted to achieve a target glass production rate of $2250 \mathrm{~kg} / \mathrm{m}^{2} /$ day with a near-complete cold cap (90-100\% of melt surface covered with feed). Quantitative measurements of glass production rates, melter operating conditions (temperatures, pressures, power, flows, etc.), and off-gas characteristics (NOx, $\mathrm{SO}_{2}$, CO, particulate load and composition, and acid gases) were made for each test. Glass samples taken from the glass pool and the discharge chamber were inspected throughout testing to determine the limit of feed $\mathrm{SO}_{3}$ concentration for operation of the melter without a separate sulfate phase.

\subsection{Test Objectives}

The principal objective of the work described in this final report was to identify and demonstrate methods to increase waste loadings in LAW Envelope C glass formulations while maintaining compliance with the current LAW glass performance requirements. This was accomplished through a combination of crucible-scale tests, screening tests on the DM10, and confirmation tests on the DM100 melter system. The DM100-WV unit was selected for these tests. The DM100-WV was used for all of the previous tests on LAW A, B, and C Sub-Envelopes [7-18] that were used to support the subsequent tests on the LAW Pilot Melter [19-30]. The same melter was selected for the present tests in order to maintain comparisons between the data sets. These tests provide information on melter processing characteristics and off-gas data, including sulfur incorporation and partitioning.

The work focused on increasing the waste loading for LAW Envelope $\mathrm{C}$ waste as well as evaluating the potential production rate increases in response to modest increases in melter operating temperature. 
The principal objectives of this work were to [31]:

- Extend the glass formulation methodology developed in the first phase of this effort [2] for LAW Envelope C waste. Develop and test an LAW Envelope C glass composition with a target $\mathrm{Na}_{2} \mathrm{O}$ concentration of $20 \mathrm{wt} \%$ and a target minimum $\mathrm{SO}_{3}$ concentration of $1.2 \mathrm{wt} \%$.

- Determine the effect of modest increase in melter operating temperature on production rate and sulfur retention in the glass product for the LAW Envelope C waste stream.

\subsection{Quality Assurance}

This work was conducted under a quality assurance program that is in place at the VSL that is based on NQA-1 (1989) and NQA-2a (1990) Part 2.7. This program is supplemented by a Quality Assurance Project Plan [36] for WTP work that is conducted at VSL. Test and procedure requirements by which the testing activities were planned and controlled are defined in the Test Plan [31]. The program is supported by VSL standard operating procedures that were used for this work [37]. The requirements of DOE/RW-0333P are not applicable to this work.

\subsection{DM100 Melter System Description}

\subsubsection{Feed System}

A schematic diagram of the DM100 vitrification system is shown in Figure 1.1. The melter feed is introduced in batches into a feed container that is mounted on a load cell for weight monitoring. The feed is stirred with a variable speed mixer and constantly recirculated except for periodic, momentary interruptions during which the weight is recorded. The way in which the feed is introduced into the melter is designed to mimic the operation of an ADS pump, which is the present WTP baseline. The recirculation loop extends to the top of the melter where feed is diverted from the recirculation loop into the melter through a Teflon-lined feed line and water-cooled feed tube. Two computer-operated pinch valves, one on the feed line and one on the recirculation loop, are activated in a timed sequence to introduce feed into the melter at the desired rate. The feed rate is regulated by adjusting the length of each pulse, the time between each pulse, and the pressure applied to the recirculation loop. A compressed air line is attached to the feed line and can be used to automatically clear the feed line into the melter after each pulse. The mixed feed enters the melter through a water-cooled, vertical feed tube. 
The Catholic University of America

Vitreous State Laboratory
LAW Envelope C Glass Formulation Testing

to Increase Waste Loading

Final Report, VSL-05R5900-1, Rev. 0

\subsubsection{Melter System}

Cross-sectional diagrams through the DM100-WV melter are shown in Figures 1.2a-c. The DM100-WV unit is a ceramic refractory-lined melter fitted with a pair of opposing Inconel 690 plate electrodes as well as a bottom electrode. The melter can be operated with either three-phase or single-phase power. However, the standard mode of operation, which was used for these tests, is single-phase with voltage applied to the side electrodes only. The bubbler used for stirring the melt pool enters from the top and is removable. The glass product is removed from the melter by means of an air-lift discharge system. The DM100-WV has a melt surface of $12 \times 14$ inches, giving a melt surface area of $0.108 \mathrm{~m}^{2}$. The nominal depth of the melt pool is about 19 inches, which gives a typical glass inventory of between 115 and $120 \mathrm{~kg}$. The plenum height is 27.5 inches. Temperatures are monitored by means of a series of thermocouples located in the melt pool, the electrodes, the plenum space, and the discharge chamber.

\subsubsection{Off-Gas System}

For operational simplicity, the DM100-WV is equipped with a dry off-gas treatment system involving gas filtration operations only. Exhaust gases leave the melter plenum through a film cooler device that minimizes the formation of solid deposits. The film-cooler air has constant flow rate and its temperature is thermostatically controlled. Consequently, under steady-state operating conditions, the exhaust gases passing through the transition line (between the melter and the first filtration device) can be sampled at constant temperature and airflow rate. The geometry of the transition line conforms to the requirements of the 40-CFR-60 air sampling techniques. Immediately downstream of the transition line are cyclonic filters followed by conventional pre-filters and HEPA filters. The temperature of the cyclonic filters is maintained above $150^{\circ} \mathrm{C}$ while the temperatures in the HEPAs are kept sufficiently high to prevent moisture condensation. The entire train of gas filtration operations is duplicated and each train is used alternately. An induced draft fan completes the system. 


\section{SECTION 2.0 WASTE SIMULANT AND GLASS FORMULATIONS}

\subsection{Waste Simulants}

The LAW Envelope C waste simulant used in the studies reported here is based on the composition data for tank AN-102 as given in a WTP Test Specification [38]. This incorporates TFCOUP [39] data, actual waste analysis data, and WTP flow sheet information. The sodium concentration in the simulant includes a $17.65 \%$ increase to account for sodium additions in pretreatment [33, 40]. The nominal concentration, expressed in terms of the sodium molarity, was determined on the basis of melter feed rheology tests on similar formulations [41, 42]. Previous tests using LAW AN-102 waste streams used glass compositions that could accommodate only lower concentrations of $\mathrm{SO}_{3}$ and which, therefore, had lower waste loadings. Melter feeds for glass compositions at lower waste loading require more dilute waste simulants because larger quantities of glass former additives are needed per unit volume of waste simulant. However, because of the higher waste loading, the glass composition and melter feed for the current LAW Envelope C composition are similar to the glass composition and melter feed for previous LAW Envelope A based on LAW AN-105 waste stream. The results of those tests led to the selection of an 8.0 molar sodium as the nominal simulant concentration for the LAW AN-102 waste.

The nominal simulant formulation is given in Table 2.1. The resulting simulant is a solution of predominantly sodium, aluminum, carbonate, nitrate, nitrite, and sulfate. Samples of the simulant were prepared according to Table 2.1 and tested at VSL. For the melter tests, Optima Chemicals, which has supplied all of the LAW simulants for the previous DM100 and LAW Pilot Melter studies, prepared the waste simulant and added the glass forming chemicals before shipment to VSL in 55-gallon drums. Sugar as a reductant and the requisite combinations of sodium hydroxide and sodium sulfate to adjust the sodium and sulfur contents of the feed for each test were added at VSL.

\subsection{Glass Formulation}

Using the previous work for LAW Envelope A as the starting point [2], four glass formulations were developed and tested to identify LAW Envelope C compositions that can accommodate higher concentrations of sulfur. Since waste loadings for Hanford LAW waste streams are directly related to sodium loading in the glasses, the testing was limited to glass compositions with a high sodium oxide concentration of $20 \mathrm{wt} \%$ with the objective of maximizing the sulfate incorporation while meeting the WTP processing and product quality requirements. Previous development work [2, 5, 33-35] for Hanford LAW tanks has indicated that the glass former additives with the most impact on sulfate solubility in the glass are lithium 
The Catholic University of America Vitreous State Laboratory
LAW Envelope C Glass Formulation Testing

to Increase Waste Loading

Final Report, VSL-05R5900-1, Rev. 0

and calcium, with lesser effect for boron, and iron; additions of vanadium and phosphorus have also been shown to be beneficial for some compositions [2, 4-6]. Lithium additions were not tested because the glass already contains high concentrations of alkali oxides ( $20 \mathrm{wt} \% \mathrm{Na}_{2} \mathrm{O}$ and $0.15 \mathrm{wt} \% \mathrm{~K}_{2} \mathrm{O}$ ). Previous testing [33, 34] has shown that addition of lithium to glasses that already contain high concentrations of other alkali oxides will likely result in unacceptable refractory corrosion characteristics and higher leach rates. $\mathrm{CaO}$ concentrations in the glasses were maintained at relatively high concentrations (8 wt\%) because high calcium content increases sulfate solubility in the glass. $\mathrm{B}_{2} \mathrm{O}_{3}$ contents were tested in the range of 13 to 13.7 wt $\%$ and silica concentrations were kept at a relatively low $36.6 \mathrm{wt} \%$ based on the results obtained for LAW Envelope A [2]. The concentration of $\mathrm{ZrO}_{2}$ was increased (3 to $6 \mathrm{wt} \%$ ) at the expense of either $\mathrm{Al}_{2} \mathrm{O}_{3}$ or $\mathrm{B}_{2} \mathrm{O}_{3}$ in order to increase glass durability, but was limited to about $6 \mathrm{wt} \%$ or less because of the tendency for crystallization of zirconium phases at $\mathrm{ZrO}_{2}$ concentrations in the glass of greater than $\approx 6.5 \mathrm{wt} \% . \mathrm{V}_{2} \mathrm{O}_{5}$ was added to all four glass compositions at a concentration of $1.0 \mathrm{wt} \%$ because it is an additive that improves sulfate solubility [2, 5-7, 43-46]; at higher concentrations it also increases sulfate volatilization from the melter during feed processing [4].

Target and analyzed compositions of the glasses that were tested are given in Table 2.2. Testing of all formulations started with glass preparation and optical microscopic evaluation of the as-melted sample. Glass samples were heat treated for 20 hours at $850^{\circ} \mathrm{C}$ and evaluated for secondary phases. All four heat treated glass samples appeared clear and homogeneous and showed no tendency for crystallization. Glass compositions were determined by x-ray fluorescence spectroscopy (XRF) on powdered glass samples, except for $\mathrm{B}_{2} \mathrm{O}_{3}$, which was measured by direct current plasma - atomic emission spectroscopy (DCP-AES) after acid dissolution. As expected, measured concentrations of volatile components such as $\mathrm{Cl}$ and $\mathrm{SO}_{3}$ are lower than target. The $\mathrm{Na}_{2} \mathrm{O}$ concentration in LAWC100 is lower than target $(18.16 \mathrm{wt} \%$ versus $20.00 \mathrm{wt} \%$ ) and the $\mathrm{SiO}_{2}$ concentration is higher than target (38.81 wt\% versus $36.62 \mathrm{wt} \%)$. The target and analyzed concentrations for all other components in LAWC100 are in good agreement. Since the difference in the target and analyzed $\mathrm{Na}_{2} \mathrm{O}$ concentration in LAWC100 could be large enough to affect its properties, a remelt of LAWC100, designated LAWC100R1, was prepared. The target and analyzed compositions of LAWC100R1 also are given in Table 2.2 and are in good agreement for all components including $\mathrm{Na}_{2} \mathrm{O}$.

The sulfate solubilities of the four new LAW Envelope C glass compositions were assessed in two ways by using batch saturation tests and gas bubbling tests. Both of these tests are crucible-scale screening tests that are used to obtain an indication of sulfur incorporation that will be obtained under actual melter operating conditions, which is, of course, the factor that is of practical importance. From past experience, the results from batch saturation tests are the simplest to perform and provide reasonable rankings of glass compositions, whereas the results from the gas bubbling tests are often in closer quantitative agreement with the results from melter tests. The batch saturation tests were performed by remelting finely ground samples of the glasses with an excess of sulfate amounting to $4 \mathrm{wt} \% \mathrm{SO}_{3}$ if all of it were retained in the glass; addition of an " $\mathrm{S}$ " at the end of a sample name indicates that the sample was remelted in this way. Results of sulfate batch saturation tests given in Table 2.3 show that the sulfate retentions of all four of the glasses were similar at around $1 \mathrm{wt} \% \mathrm{SO}_{3}$, with the retention for LAWC100 
The Catholic University of America Vitreous State Laboratory
LAW Envelope C Glass Formulation Testing

to Increase Waste Loading

Final Report, VSL-05R5900-1, Rev. 0

being marginally higher than the rest. Table 2.3 lists three analyzed compositions for each of the new LAW Envelope C glasses. The analyzed compositions identified as "XRF" are XRF analyses of glass samples remelted with $4 \mathrm{wt} \% \mathrm{SO}_{3}$. The compositions identified as "XRF after washing" are analyses of glass samples remelted with $4 \mathrm{wt} \% \mathrm{SO}_{3}$ after grinding and washing to remove any interstitial sulfate phases, so that only the $\mathrm{SO}_{3}$ that is dissolved in the glass is measured. The compositions identified as "DCP" are DCP-AES analyses of the above glass samples after grinding and washing to remove interstitial sulfate phases.

As stated above, sulfate solubilities of the four new LAW Envelope C glasses were also determined by gas bubbling tests. In these tests, a sample of the test glass that does not contain any sulfate is melted in a platinum crucible and held at a constant temperature of $1150^{\circ} \mathrm{C}$. Mixtures of $\mathrm{SO}_{2}$ and $\mathrm{O}_{2}$ are then bubbled through the glass melt at controlled flow rates through a platinum tube. From the flow rates and the temperature, together with known thermodynamic data, the partial pressure of $\mathrm{SO}_{3}$ can be calculated. Samples of the glass melt are removed at selected time intervals and subjected to analysis by XRF to determine their sulfur content. Prior to analysis, the glass samples are ground and washed to remove any sulfate phase that might adhere to the sample in order to determine only the sulfate that is dissolved in the glass. Figure 2.1 shows the results of these tests; also shown are the results for the previously tested high sulfate LAW Envelope A glass, LAWA161, and an early LAW glass formulation (LAWPC1) which showed a very low sulfate incorporation of about 0.37 wt $\%$ in melter tests $[32,47]$. The results clearly show that the four new LAW Envelope C glasses and LAWA161 exhibit similar sulfate incorporation and, compared to LAWPC1, a significant increase in sulfate incorporation both in terms of a higher solubility limit and a lower activity coefficient for $\mathrm{SO}_{3}$ in the melt. The results of sulfate solubility determinations by batch saturation tests and gas bubbling tests are given in Figure 2.2. The results show that when both tests are considered, LAWC100 shows the highest potential for sulfate incorporation.

Vapor Hydration Test (VHT) and Product Consistency Test (PCT) results are summarized in Table 2.4 and illustrated in Figures 2.3 and 2.4. VHT test results given in Table 2.4 and Figure 2.3 show that for all glasses, the VHT alteration rates remained well below the contract limit. Note that the VHT results are presented in Figure 2.3 with a fairly large relative standard deviation estimated at about $43 \%$ on average, based on replicate VHT measurements [48]. The difference in the measured $\mathrm{Na}_{2} \mathrm{O}$ concentrations does not seem to have a significant effect on the VHT alteration rates for LAWC100 and LAWC100R1. PCT responses for the glasses given in Table 2.4 and Figure 2.4 show that the mass losses for all glasses are less than about half of the contract limit. LAWC100R1 shows higher PCT releases than LAWC100, probably due to its higher measured $\mathrm{Na}_{2} \mathrm{O}$ content. The measured viscosities and electrical conductivities of the four glasses at selected temperatures are given in Table 2.5. LAWC100R1 shows lower viscosity and higher electrical conductivity as compared to LAWC100, again, likely due its higher measured $\mathrm{Na}_{2} \mathrm{O}$ content. The densities and glass transition temperatures are given in Table 2.6. K-3 refractory corrosion test results for the glasses are given in Table 2.7 and Figure 2.5, where they are compared to the results for the previously tested LAW Envelope A glass (LAWA161) and two WTP baseline formulations with $20 \mathrm{wt} \% \mathrm{Na}_{2} \mathrm{O}$ (LAWA44 and LAWA88). The measured properties of the glass LAWC100 are compared to the ILAW 
The Catholic University of America Vitreous State Laboratory
LAW Envelope C Glass Formulation Testing

to Increase Waste Loading

Final Report, VSL-05R5900-1, Rev. 0

performance requirements [49] in Table 2.8. As is evident from Table 2.8, glass LAWC100 meets all of the ILAW performance requirements. Based on the higher sulfur incorporation and the above test results, the LAWC100 glass composition was selected for subsequent melter testing. The composition and properties of the LAWC100 glass are compared to those of previous Sub-Envelope C2 glass formulations in Section 7.

The composition of the LAWC100 glass used in melter tests is given in Table 2.9 along with the oxide contributions from the LAW AN-102 waste simulant and the glass former additives. The melter feed was procured at a $\mathrm{SO}_{3}$ concentration of $0.75 \mathrm{wt} \%$ and the sulfur concentration was increased in steps during the melter tests by adding the appropriate amount of $\mathrm{Na}_{2} \mathrm{SO}_{4}$ to the feed. The melter feed was procured at a $\mathrm{Na}_{2} \mathrm{O}$ concentration of $19.42 \mathrm{wt} \%$ in order to accommodate sodium sulfate additions, without increasing the $\mathrm{Na}_{2} \mathrm{O}$ concentration above $20.0 \mathrm{wt} \%$. The types and amounts of glass former additives used to prepare the melter feed along with the feed properties are given in Table 2.10. $\mathrm{NaOH}$ and $\mathrm{Na}_{2} \mathrm{SO}_{4}$ additions to the melter feed to obtain $\mathrm{SO}_{3}$ concentrations in the range of 0.75 to $1.5 \mathrm{wt} \%$ are given in Table 2.11. The glass former additives are the same as those planned for use at the Hanford Waste Treatment Plant (WTP), with the exception of vanadium, which was added to improve sulfate solubility [2, 5-7, 43-46].

\subsection{Sugar Additions}

With high nitrate feeds, the addition of reductants is necessary in order to control melt foaming. Sugar, which was used for this purpose at West Valley, has also been selected as the baseline reductant for the WTP. The amount of sugar required increases with the amount of nitrates present in the feed and decreases with the amount of waste organics present in the feed, which themselves act as reductants. Excessive additions of reductants can be deleterious, leading to over-reduction of the melt and formation of sulfides and molten metals. Consequently, the oxidants and reductants in the feed must be suitably balanced. The basis for achieving this balance was developed by VSL and Duratek for the vitrification of high-sodium-nitrate feeds at Savannah River's M-Area and has been successfully applied to the processing of a wide variety of simulated WTP feeds over the past six years. In developing this approach, we elected to conservatively adopt the most reducing potential reaction as the basis for the definition of a "sugar" or stoichiometric ratio of 1.0 as a result of concerns for over-reducing the melt. Such a reaction, using sodium salts as an example, is:

$$
\mathrm{C}_{12} \mathrm{H}_{22} \mathrm{O}_{11}+8 \mathrm{NaNO}_{3}=8 \mathrm{CO}_{2}+4 \mathrm{CO}+4 \mathrm{~N}_{2}+11 \mathrm{H}_{2} \mathrm{O}+4 \mathrm{Na}_{2} \mathrm{O}
$$

Fundamentally, the basis that is selected is simply a convention, since the precise stoichiometry of the reactions involved is neither known nor constant under the conditions prevailing in the melter. However, with this convention, a sugar ratio of 1.0 corresponds to one mole of sucrose per eight moles of nitrate or, more generally, 1.5 moles of organic carbon per mole of nitrate. It is then expected that significantly less sugar than this will be required in practice. The

empirically determined amount required to successfully control melt foaming without 
significantly reducing the glass melt was found to correspond to a ratio of 0.5 when any nitrites present were counted as nitrates (i.e., 0.75 moles of organic carbon per mole of nitrate + nitrite). This approach has been employed for all WTP melter testing. It is, however, expected that slight variations around the nominal value of 0.5 may be necessary to account for differences in the reducing power of waste organics in comparison to sugar, particularly for LAW streams that are high in organics.

As an example, the calculation of the amount of sugar needed for the present LAW Envelope $\mathrm{C}$ feed to achieve a sugar ratio of 0.5 proceeds as follows:

- One liter of 8 Molar sodium simulant contains 1.503 moles of nitrite and 2.887 moles of nitrate, giving a total of 4.390 moles of NOx (see Table 2.1)

- Required total amount of organic carbon for a sugar ratio of 0.5 is $4.390 \times 0.75=3.293$ moles

- $\quad$ One liter of simulant contains 1.965 moles of organic carbon (see Table 2.1)

- $\quad$ Therefore, $3.293-1.965=1.328$ moles of organic carbon must be added.

Since the molecular weight of sucrose is $342 \mathrm{~g}, 1.328 \times 342 / 12=37.85 \mathrm{~g}$ sugar must be added per liter of simulant, as shown in Table 2.10.

\subsection{Analysis of Feed Samples}

\subsubsection{General Properties}

Feed samples were analyzed from melter and crucible tests to confirm physical properties and chemical composition. Samples taken during melter testing were from an inline sampling port. Sample names, sampling dates, measured properties and target values are given in Table 2.12 along with corresponding average measured values from previous tests with a similar melter feed [2]. The measured values from feeds produced at the crucible scale are very close to the targets at two different sulfur contents. The melter feed samples have higher water contents and slightly lower densities and glass yields than the target values due perhaps to high estimates in the purity of the additives as well as water added during the transfer of feed. The average measured glass yield for the melter samples however was only about $7 \%$ below the target value, validating the use of the target value for calculating glass production rates. Measured feed properties for feed from the previous [2] and current test are very similar due to the similarity in the product glass produced; the $\mathrm{pH}$ values are very different, however, due to the much higher hydroxide concentration in the LAW Envelope A simulant.

\subsubsection{Rheology}

Samples of the melter and crucible scale feeds that were used for these tests were also subjected to rheological characterization. The results from rheological characterization of a 
The Catholic University of America Vitreous State Laboratory
LAW Envelope C Glass Formulation Testing

to Increase Waste Loading

Final Report, VSL-05R5900-1, Rev. 0

variety of other melter feeds and waste simulants, as well as the effects of a range of test variables, are described in detail in separate reports [41, 42]. Melter feeds were characterized using a Haake RS75 rheometer, which was equipped with either a Z40DIN or a FL22-SZ40 sensor. A typical set of measurements consists of identifying the flow characteristics of the slurry by measuring the shear stress on the slurry at controlled shear rates and temperatures. In these measurements, the shear rate values are preset and are increased stepwise from $0.01 \mathrm{~s}^{-1}$ to $200 \mathrm{~s}^{-1}$ (70 $\mathrm{s}^{-1}$ for FL22-SZ40) with a sufficient delay (typically 15 to 30 seconds) between steps to ensure that shear stress is allowed to fully relax and therefore is measured at equilibrium. This approach is somewhat different from the "flow curve" approach in which the shear rate is ramped up to some maximum value and then ramped back down to produce a hysteresis curve that is dependent on the selected ramp rate. The viscosity of the sample as a function of the shear rate is then calculated as the ratio of the shear stress to the shear rate. The yield stress data for the melter feeds were measured using a controlled-stress mode in which the torque on the rotor was slowly increased while the resulting deformation of the fluid was monitored. The discontinuity in the measured deformation-torque curve was identified as the yield stress. It should be noted that this direct measurement of the yield stress can be quite different from the value that is often reported as the yield stress, which is obtained by extrapolation of the shear stress-shear rate curve to zero shear rate. All of the measurements in this work were made at $25^{\circ} \mathrm{C}$; previous work [41], which examined a range of temperatures, showed a relatively weak effect of temperature.

Rheograms for the melter and crucible scale feeds, which show the feed viscosity versus shear rate, are presented in Figure 2.6. Also included in Figure 2.6 are values measured for feed from the previous DM100 test using a LAW Envelope A simulant that produced a similar glass product to the target composition in the current tests [2]. Figure 2.7 shows an alternative presentation of the data as plots of the shear stress versus shear rate; also included are proposed WTP bounds for feed rheology [50]. Measured yield stress and viscosity at selected shear rates are given in Table 2.12. The rheological properties of the two crucible scale feeds are virtually identical to each other, indicating that the change in sulfur concentration has no effect on rheological properties. The crucible scale feeds are slightly more viscous than the melter feeds at shear rates greater than 1 /second due to the lower concentration of water in the crucible scale feeds. At lower shear rates, the melter feed is actually more resistant to flow, as illustrated by the higher yield stress values. The LAWC100 and LAWA161 feeds have very similar rheological properties as a result of the similarity in glass composition and additives used. The rheological properties for all feed samples are well within the proposed WTP bounds. No difficulties were encountered in processing this feed.

\subsubsection{Chemical Composition}

The chemical compositions of the feed samples were determined by first making a glass from the feed sample via crucible melt. The glass was subsequently crushed and analyzed directly by X-Ray Fluorescence Spectroscopy (XRF). The boron oxide target value was used for normalizing the XRF data since its concentration was not determined by XRF. The results, which are compared to the target compositions in Table 2.13, generally corroborate the consistency of 
The Catholic University of America

Vitreous State Laboratory
LAW Envelope C Glass Formulation Testing

to Increase Waste Loading

Final Report, VSL-05R5900-1, Rev. 0

the feed composition and show good agreement with the target composition for the major components. Of the oxides with a target concentration of one percent or greater, only magnesium and vanadium oxides had a deviation of greater than $10 \%$ from target. This deviation was also observed in the product glasses but was considerably smaller in magnitude (see Section 5.1). Deficits of magnesium oxide measured in the feed samples being substantially less in the product glass have been observed in several previous studies [3, 4, 9, 10, 51-53]. The vanadium surplus is about half as large in the product glasses and significantly less than $10 \%$ from target in the DCP analysis of dissolved product glass samples. The latter suggests a potential high analytical bias for vanadium using the XRF analysis [2]. Titanium oxide was measured in the feed samples at about a fifth of a weight percent even though it was not included in the target composition. Similar observations were made in previous tests with LAW melter feeds [9, 1013,16 -18] due to its presence as a contaminant in the glass forming additives, most notably kyanite [2]. Volatile minor elements such as sulfur, iodine, and chlorine are, as expected, below target due to loss during crucible melting. The target sulfur concentrations in the feed, which is important for determining sulfur retention in the glass, are verified from the simulant vendor's batching sheets. Additional amounts of sulfur added by the VSL are calculated, checked, and weighed out using calibrated balances. 


\section{SECTION 3.0 DM10 SCOPING TESTS}

Melter tests were conducted on the DM10 with the LAW Envelope C simulant between $5 / 19 / 05$ and 5/25/05 to screen sulfur concentrations at three glass temperatures for future use on the DM100-WV. These tests produced over 230 kilograms of glass from almost half a metric ton of feed. The tests, listed in the order in which they were performed, were as follows:

- Test C1: Three nominally $14-15$ hour feeding segments at a glass temperature of $1150^{\circ} \mathrm{C}$ with target $\mathrm{SO}_{3}$ concentrations of 1.0, 1.25, and $1.125 \mathrm{wt} \%$ in the glass product (assuming total retention). The duration of second test segment was cut short due to secondary sulfate observations in the discharged glass.

- Test C2: Three nominally $14-15$ hour feeding segments at a glass temperature of $1175^{\circ} \mathrm{C}$ with target $\mathrm{SO}_{3}$ concentrations of $1.125,1.25$, and $1.375 \mathrm{wt} \%$ in the glass product (assuming total retention).

- Test C3: Three nominally $14-15$ hour feeding segments at a glass temperature of $1200^{\circ} \mathrm{C}$ with target $\mathrm{SO}_{3}$ concentrations of $1.375,1.625$, and $1.625 \mathrm{wt} \%$ in the glass product (assuming total retention).

The principal objective of these tests was to determine the maximum amount of sulfur that can be fed into the melter at three different glass temperatures without forming secondary sulfate phases. Processing conditions, including a target production rate of $2250 \mathrm{~kg} / \mathrm{m}^{2} / \mathrm{day}$ and a complete cold cap, mimicked those to be used on the DM100. Test segment durations of 14 hours were selected since, at the target glass production rate, this provided three melt pool turnovers $(24 \mathrm{~kg})$ for each sulfur concentration. Sugar was added to the feed at a stoichiometric carbon ratio of 0.5 for all of the DM10 tests.

\subsection{DM10 System Description}

\subsubsection{Feed System}

The feed container is mounted on a load cell for weight monitoring and is stirred continuously except for periodic, momentary interruptions during which the weight is recorded. The material in the feed container is constantly recirculated, which provides additional mixing. The recirculation loop extends to the top of the melter where feed is diverted from the recirculation loop through a peristaltic pump into the melter through a Teflon-lined feed line and vertical water-cooled feed tube. A diverter valve permits direction of the feed stream either to the melter or to a sampling vessel. 


\subsubsection{Melter}

The DM10 system used for this work is a ceramic refractory lined melter, which includes two Inconel 690 plate electrodes that are used for joule-heating of the glass pool and a bubbler for agitating the melt. Glass is discharged from the melter using an air-lift system. The melt pool has a surface area of $0.021 \mathrm{~m}^{2}$ and typically contains about $8 \mathrm{~kg}$ of glass. The plenum volume is 19.5 liters at the nominal glass level.

\subsubsection{Off-Gas System}

For operational simplicity, the DM10 is equipped with a dry off-gas treatment system involving gas filtration operations only. Exhaust gases leave the melter plenum through a film cooler device that minimizes the formation of solid deposits. The film cooler air has constant flow rate and its temperature is thermostatically controlled. The geometry of the transition line (between the melter and the first filtration device) conforms to the requirements of the 40-CFR-60 air sampling techniques. Immediately downstream of the transition line are cyclonic filters followed by conventional pre-filters and HEPA filters. The temperature of the cyclonic filters is maintained above $150^{\circ} \mathrm{C}$ while the HEPAs are held above $100^{\circ} \mathrm{C}$ to prevent moisture condensation. The entire train of gas filtration operations is duplicated and each train is used alternately. An induced draft fan completes the system. The sampling location for gaseous species monitored by FTIR is immediately downstream of the draft fan.

\subsection{DM10 Test Results}

Table 3.1 provides a summary of the DM10 tests including run times, the amount of sulfur in the feed, the amount of feed sulfur retained in the glass product, observations of secondary phases, and glass processing temperatures. A listing of all the glasses discharged, observations of secondary phases, and sulfur contents determined by XRF analysis of each glass sample is given in Table 3.2. Sulfur compositional trends over the course of the tests are depicted in Figure 3.1. A listing of all the dip glass samples taken (by dipping a metal rod into the melt pool) to detect any secondary phases on the melt pool surface is given in Table 3.3. The stack exhaust was analyzed for a variety of gaseous species using FTIR (see Section 6.2); no $\mathrm{SO}_{2}$ was detected in any of the tests and therefore no FTIR data are reported in this section.

The DM10 tests were successful in determining the concentration of feed sulfur that can be processed at $1150^{\circ} \mathrm{C}$ and $1175^{\circ} \mathrm{C}$ glass temperatures in preparation for the DM100 tests. However, the DM10 tests were complicated by problems encountered in measuring the glass pool temperature at the higher target temperatures as a result of the rapid corrosion of the Inconel 601 thermowells. Inconel 601 has been used in the DM10 in place of the prototypical and more corrosion resistant Inconel 690 because of the lack of material availability in the much smaller size. However, the required replacement rate was found to be impractical for these high-sulfate feeds at higher test temperatures. As a result, Inconel 690 thermowells have been custom 
The Catholic University of America Vitreous State Laboratory
LAW Envelope C Glass Formulation Testing

to Increase Waste Loading

Final Report, VSL-05R5900-1, Rev. 0

fabricated for the subsequent DM10 tests. After replacing several thermowells during these tests, the glass temperature was measured periodically by inserting thermocouples directly into the glass pool. The limitation of this method is that temperature could not be monitored continuously and that thermocouples failed frequently. The electrode temperature was used as a secondary indication of the melt pool temperature by assuming a constant off-set from the melt pool temperature. A further qualitative indication of the glass temperatures was the decreasing amount of bubbling required to produce glass at the target rate of $2250 \mathrm{~kg} / \mathrm{m}^{2} /$ day. In subsequent tests, thermowells made of Inconel 690 were used with none of these corrosion problems.

Tests conducted at $1150^{\circ} \mathrm{C}$ provided clear indications concerning the amount of feed sulfur that can be processed without forming secondary phases. At a feed sulfur content of $1.25 \mathrm{wt} \% \mathrm{SO}_{3}$ on a glass basis, secondary sulfate phases were observed in both the dip samples and the discharge product, indicating that the glass is clearly supersaturated with respect to sulfur. Secondary phases on the glass surface and in discharge product were no longer observed after reducing the feed sulfur concentration to $1.125 \mathrm{wt} \% \mathrm{SO}_{3}$ on a glass basis. The concentration of feed sulfur that the process can tolerate therefore is between 1.125 and $1.25 \mathrm{wt} \% \mathrm{SO}_{3}$ on a glass basis. The maximum analyzed concentration of sulfur in the product glass without secondary phases was about $1.07 \mathrm{wt} \% \mathrm{SO}_{3}$, which corresponds to $95 \%$ retention of feed sulfur.

Results from the melter tests at the two higher temperatures do not provide as clear an indication of the ability of glass to retain sulfur without forming secondary phases. No secondary sulfur phases were observed in any of the discharged products during the $1175^{\circ} \mathrm{C}$ and $1200^{\circ} \mathrm{C}$ tests. Trace amounts of secondary sulfate were observed on a dip sample at the end of the test processing feed with a sulfur concentration of $1.375 \mathrm{wt} \% \mathrm{SO}_{3}$ on a glass basis at the $1175^{\circ} \mathrm{C}$ glass temperature, suggesting that the process was at or near the saturation point. The maximum analyzed concentration of sulfur in the glass without secondary phases was estimated at $1.2 \mathrm{wt} \%$ $\mathrm{SO}_{3}$, which corresponds to $90-95 \%$ retention of feed sulfur. At a melt temperature of $1200^{\circ} \mathrm{C}$, it was very difficult to maintain a complete cold cap, even after reducing bubbling to minimal flow rates. The feed showed a "boiling" appearance on the melt surface and was rapidly consumed even during Test C3C when the feed rate was maximized. A thin layer was observed on the open glass surface which, when sampled, was found to be sulfate. The measured concentration of sulfur in the glass decreased during tests conducted at $1200^{\circ} \mathrm{C}$, even though the sulfur concentration in the feed was increased, supporting the observation that sulfur was being boiled off the melt surface and not being incorporated into the glass pool. The lack of sulfur dioxide in the melter exhaust suggests that the sulfur was emitted as alkali sulfate particles and/or sulfuric acid.

\subsection{Feed Sulfur Concentrations Selected from DM10 Tests}

Based on the results from the DM10 tests, feed sulfur concentrations of 1.1 and $1.3 \mathrm{wt} \%$ $\mathrm{SO}_{3}$ on a glass basis were selected for processing on the $\mathrm{DM} 100$ at $1150^{\circ} \mathrm{C}$ and $1175^{\circ} \mathrm{C}$ glass temperature, respectively. Both of these concentrations were below feed levels that resulted in secondary phase formation in DM10 tests. 
The Catholic University of America Vitreous State Laboratory
LAW Envelope C Glass Formulation Testing

to Increase Waste Loading

Final Report, VSL-05R5900-1, Rev. 0

\section{SECTION 4.0 DM100 OPERATIONS}

Melter tests were conducted on the DM100-WV with the LAW Envelope C simulant between 6/2/05 and 6/10/05. These tests produced over $1700 \mathrm{~kg}$ of glass from approximately three and a half metric tons of feed; the tests are summarized in Table 4.1. The tests were 176 hours in duration and were divided as follows:

- Test 1: Glass temperature $1150^{\circ} \mathrm{C}, 1.1 \mathrm{wt} \% \mathrm{SO}_{3}, 2250 \mathrm{~kg} / \mathrm{m}^{2} /$ day production rate.

- Test 2a: Glass temperature $1175^{\circ} \mathrm{C}, 1.3 \mathrm{wt} \% \mathrm{SO}_{3}, 3300 \mathrm{~kg} / \mathrm{m}^{2} /$ day production rate.

- Test 2b: Glass temperature $1175^{\circ} \mathrm{C}, 1.3 \mathrm{wt} \% \mathrm{SO}_{3}, 2250 \mathrm{~kg} / \mathrm{m}^{2} /$ day production rate.

- Test 2c: Glass temperature $1175^{\circ} \mathrm{C}, 1.23 \mathrm{wt} \% \mathrm{SO}_{3}, 2250 \mathrm{~kg} / \mathrm{m}^{2} /$ day production rate.

- Test 2d: Glass temperature $1175^{\circ} \mathrm{C}, 1.15 \mathrm{wt} \% \mathrm{SO}_{3}, 2250 \mathrm{~kg} / \mathrm{m}^{2} /$ day production rate.

- Test 2e: Glass temperature $1175^{\circ} \mathrm{C}, 1.15 \mathrm{wt} \% \mathrm{SO}_{3}, 2250 \mathrm{~kg} / \mathrm{m}^{2} /$ day production rate, stoichiometric carbon ratio increased from 0.5 to 0.8 with sugar.

Test 2 was planned as a single 60-hour test segment at a single sulfur feed concentration, production rate, and stoichiometric carbon ratio but, as a result of observations made during the test, the test was completed in five contiguous segments over 90 hours at multiple sulfur feed concentrations, production rates, and sugar ratios. Deviations from the tests matrix were made in response to observations of secondary sulfate phases in the discharged product followed by observations of secondary sulfate phases on glass dip samples. In an effort to determine the maximum feed sulfur concentration that can be processed without forming separate sulfate phases on the glass pool surface or product glasses, several approaches were explored. First, the production rate was lowered from 3300 to $2250 \mathrm{~kg} / \mathrm{m}^{2} /$ day to determine if the rate of sulfur incorporation into the glass melt, rather than solubility, was responsible for the formation of the secondary sulfur phases (note that the higher glass production rate was a natural consequence of operating at the higher glass temperature with the same bubbling rate). However, a sulfate phase was again observed on dip and discharged samples after the processing rate reduction. Therefore, in response, a decision was made to reduce the feed sulfur concentration, which was done in two successive steps. After the sulfur feed concentration was reduced to $1.15 \mathrm{wt} \% \mathrm{SO}_{3}$ on a glass basis, a sulfate phase was no longer observed on the glass dip samples, indicating the absence of a sulfate layer on the melt pool surface; however, separate sulfate was observed on the surface of the discharged glass. In response to this observation, instead of further reducing the concentration of sulfur in the feed, additional sugar was added to the feed. The rationale for this was that the amount of sugar was less for the Envelope $C$ tests than for the previous Envelope A tests [2] as a result of the presence of high levels of waste organics in the Envelope $\mathrm{C}$ simulant. Therefore, the sugar level was increased to bring the stoichiometric carbon ratio from 0.5 to 0.8 , which would correspond to a ratio of 0.5 if the waste organics were ignored (see Section 2.3). This approach is based upon the observation that many waste organic compounds such as oxalic and formic acids are not as effective reductants as sugar [15, 54]. Despite this change, the results from the test with additional sugar were the same as for the preceding test: a separate sulfate was 
The Catholic University of America Vitreous State Laboratory
LAW Envelope C Glass Formulation Testing

to Increase Waste Loading

Final Report, VSL-05R5900-1, Rev. 0

not observed on dip glass samples but was observed on the surface of the discharged glass. The appearance of the sulfate phase on the discharge glass was suspicious in that it showed no signs of having separated out from the underlying glass but rather appeared to have been simply mechanically included.

There are several possible mechanisms for the sulfate inclusions seen in the discharge glass, the most likely of which is that a transient sulfate phase from the melt surface migrated through the discharge chamber wall into the discharge chamber. However, it is also possible that glass migrated to the floor of the discharge chamber where it partially cooled, which reduced the sulfur solubility, and thereby lead to the formation of a separate sulfate phase, which was extruded onto the discharged glass surface at the end of the glass discharges when the discharge chamber was at its highest temperature. A third possibility is a sulfate phase that volatilized, deposited in the discharge chamber, and subsequently melted and entrained in the discharge glass as the temperature of the discharge chamber increased during glass discharge. In view of these possibilities, in the subsequent tests performed on this melter using Envelope A and B feeds, this problem was successfully mitigated by operating the discharge chamber at a somewhat lower temperature. However, on completion of those tests, the lid and discharge chamber were removed in order to allow a more thorough inspection. The results of that inspection, which are presented in the Envelope A \& B test report, indicated that over six years of operations, the bricks in the wall between the discharge chamber and the melt pool had thinned considerably in an area surrounding a seam in the bricks, which would allow migration of glass, and particularly the much more fluid molten sulfate, into the discharge chamber.

In light of these findings, we are convinced that the observation of separate sulfate on the surface of discharge cans was not a true indication of the tendency of the glass melt to form secondary sulfate phases during routine processing, which is consistent with the absence of any sulfate phase on the dip samples. The glass dip samples are therefore the most reliable means of determining the capacity of the glass to retain sulfur without forming secondary phases. Based on this criterion, 1.1 and 1.15 wt.\% $\mathrm{SO}_{3}$ on a glass basis were the sulfur feed concentrations that were processed without the formation of secondary phases at $1150^{\circ} \mathrm{C}$ and $1175^{\circ} \mathrm{C}$ glass temperatures, respectively. These results were obtained at a production rate of $2250 \mathrm{~kg} / \mathrm{m}^{2} / \mathrm{day}$; the data that were collected were not sufficient to determine if the same results would be obtained at higher production rates.

For comparison purposes, to the extent possible, attempts were made to replicate the melter configuration and operating conditions used for the corresponding tests conducted earlier [2-4] and the previous LAW Sub-Envelope [9-18] tests. These conditions include a nearcomplete cold cap, which is between $80-95 \%$ melt surface coverage for the DM100, since a $100 \%$ cold cap tends to lead to "bridging" in smaller melters. Glass production rates calculated from feed consumption are depicted in Figure 4.1 . The target production rate of $2250 \mathrm{~kg} / \mathrm{m}^{2} /$ day was obtained and maintained throughout Test 1 once the cold cap was established. The bubbling rate used to achieve this production rate, $17.1 \mathrm{lpm}$, was held constant throughout Test 2a and the feed rate was adjusted to provide a near complete cold cap. The increase in glass temperature to $1175^{\circ} \mathrm{C}$ resulted in a production rate increase to $3300 \mathrm{~kg} / \mathrm{m}^{2} /$ day. This near $50 \%$ increase in 
The Catholic University of America Vitreous State Laboratory
LAW Envelope C Glass Formulation Testing

to Increase Waste Loading

Final Report, VSL-05R5900-1, Rev. 0

production rate for a $25^{\circ} \mathrm{C}$ increase in glass pool temperature is even greater than for previous tests, where a $75^{\circ} \mathrm{C}$ increase in glass pool temperature was required with LAW Envelope A simulants to achieve a similar production rate increase [3]. The differences may be due in part to composition modifications made to the Envelope A glass to accommodate higher temperatures, which increased its viscosity, but may also be related to the higher sulfate content. Note that the average production rate for Test $2 \mathrm{a}$ is significantly less than the steady-state rate due to the increase in rate over the course of the test and the inclusion of a half-hour period without feeding due to a building-wide power outage. Production rates were again targeted and maintained at $2250 \mathrm{~kg} / \mathrm{m}^{2} /$ day during Tests $2 \mathrm{~b}-2 \mathrm{e}$. As typically observed, production rates vary from the target at the onset of feeding while the cold cap becomes established; in addition, instantaneous rates varied by as much as $25 \%$ as a result of variable feed pulse sizes. No processing problems were observed and no interruptions were experienced due to feed system clogging. Glass production rates measured during the current test along with those measured during previous LAW Sub-Envelope C2 tests on the DM100 and LAW Pilot Melter are compared in Section 7.

The results of various operational measurements that were made during these tests are given in Table 4.2. Glass temperatures are shown in Figure 4.2, plenum temperatures in Figure 4.3, electrode temperatures in Figure 4.4, melt pool bubbling in Figure 4.5, and power supplied to the electrodes in both Figures 4.3 and 4.4. Bulk glass temperatures approximated the target glass temperatures of $1150^{\circ} \mathrm{C}$ and $1175^{\circ} \mathrm{C}$ for the respective tests. Glass temperatures near the top of the melt pool are not reliable indicators of bulk glass temperatures as a result of gradients near the cold cap. Plenum temperatures typically ranged within the 450 to $650^{\circ} \mathrm{C}$ target and were mostly between 500 to $600^{\circ} \mathrm{C}$. The increase in glass temperature did not noticeably affect the plenum temperature due to the maintenance of a complete cold cap throughout testing. Conversely, electrode temperatures increased with increasing glass temperature, particularly for the west and bottom electrode. The west electrode temperature was typically $20-35^{\circ} \mathrm{C}$ cooler than the bulk glass and was $40-80^{\circ} \mathrm{C}$ and $190-220^{\circ} \mathrm{C}$ hotter then the east and bottom electrodes, respectively. The bottom electrode was not powered during these tests. Power supplied to the electrodes was relatively constant at about $24 \mathrm{~kW}$ in tests producing glass at $2250 \mathrm{~kg} / \mathrm{m}^{2} /$ day, except in the last test where additional sugar was included in the feed. As the production rate increased to $3300 \mathrm{~kg} / \mathrm{m}^{2} /$ day, power demand increased to over $30 \mathrm{~kW}$. For test 2e, power demand decreased by about $2 \mathrm{~kW}$ as a result of more sugar additions to the feed, and the energy released from the combustion of the additional organics. An average bubbling rate of $17.1 \mathrm{lpm}$ was required to obtain the target production rate of $2250 \mathrm{~kg} / \mathrm{m}^{2} /$ day during Test 1 ; per the Test Plan, this same bubbling rate was used at the onset of Test $2 \mathrm{a}$ to determine the effect of glass temperature on production rate. The bubbling rate decreased to between 10.5 to $12.5 \mathrm{lpm}$ during Tests $2 b-2 d$ in response to a decrease of the production rate back to $2250 \mathrm{~kg} / \mathrm{m}^{2} / \mathrm{day}$. Bubbling was further decreased in Test 2e by a factor of almost two in response to the addition of more sugar to the feed. These decreases in bubbling rate while processing at a glass temperature of $1175^{\circ} \mathrm{C}$ and a production rate of $2250 \mathrm{~kg} / \mathrm{m}^{2} /$ day further illustrate that significant increases in production rate are possible with only modest increases in glass pool temperature.

The discharge chamber temperature was maintained at about $1000^{\circ} \mathrm{C}$ throughout the tests. This practice is in keeping with all previous tests and is intended to prevent glass from "freezing" 
The Catholic University of America

Vitreous State Laboratory
LAW Envelope C Glass Formulation Testing

to Increase Waste Loading

Final Report, VSL-05R5900-1, Rev. 0

in the chamber during discharge. Over several years of use, which has included extended idling periods such as the ten month hiatus between the current test and the previous test [54], glass has begun to migrate into the discharge chamber through a thinned area around a seam in the bricks near the discharge chamber. More recently, the discharge chamber temperature has been reduced to $850^{\circ} \mathrm{C}$, which appears to have stopped glass from migrating into the discharge chamber without hampering the desired flow of glass by the air lift. This approach was used in the remaining LAW Envelope A and B tests described in the Test Plan [31]. After completion of those tests, the discharge chamber was removed and inspected to further investigate and, if possible, rectify the glass migration pathway. Inspection indicates that the thinned area around a seam in the bricks is near the glass level in the melter. For future tests, the melter will, therefore, be operated at a slightly lower glass level in order to reduce glass migration. This, combined with a lower operating discharge chamber temperature, are expected to mitigate glass migration until repairs are made to the DM100-WV.

The gas temperature at the film cooler and transition line outlet averaged from 298 to $282^{\circ} \mathrm{C}$, depending on the plenum temperature as well as the amount and temperature of the added film cooler air. Little or no drop in gas temperature was observed across the (insulated) transition line, which serves to prevent condensation, as intended. 
The Catholic University of America

Vitreous State Laboratory
LAW Envelope C Glass Formulation Testing

to Increase Waste Loading

Final Report, VSL-05R5900-1, Rev. 0

\section{SECTION 5.0 DM100 GLASS PRODUCTS}

Over $1700 \mathrm{~kg}$ of glass was produced in these tests. The glass was discharged from the melter periodically into 5-gallon carbon steel pails using an airlift system. The discharged product glass was sampled at the end of each test by removing sufficient glass from the top of the cans for total inorganic analysis. Care was exercised during sampling of each pail to segregate any secondary phases that were observed; these constituted less than one weight percent and in most pails less than a tenth of a weight percent of the bulk glass. Additional samples were taken from the end of Test 1 and sealed in containers for shipment to ORP, as required in the Test Plan. Product glass masses, discharge date, analysis performed, and observations of secondary phases are listed in Table 5.1. Glass samples were also obtained by dipping a rod into the glass pool at the beginning and end of each test. These "dip samples" underwent visual examinations to detect the presence of a separate sulfate phase on the glass pool surface.

\subsection{Compositional Analysis}

Glass discharge samples were crushed and analyzed directly by XRF. No visible secondary phases were included in the samples used for compositional analysis. The target value for boron oxide, which is not determined by XRF, was used for normalizing the XRF data to $100 \mathrm{wt} \%$. The XRF-analyzed compositions of all discharged glass samples are provided in Table 5.2 and, for selected samples, are compared with the results of DCP analysis of solutions generated by microwave aided acid dissolution in Table 5.3. The majority of the XRF analysis results compared very favorably to their corresponding target values. The only oxide with a target oxide concentration of one percent or more to deviate from target by more than ten relative percent was vanadium oxide; the measured absolute deviation from target for vanadium was only $0.12 \mathrm{wt} \%$. Measured boron concentrations were within two percent of the target, validating the use of the target value for normalizing the XRF data. Agreement between the two analytical methods was excellent, except for low sodium values obtained from the DCP analysis, which is likely due to a low-bias for sodium; previous experience indicates that the XRF results are more reliable in this regard. Another comparison of note is the higher vanadium concentrations measured by DCP, supporting the notion of a small but consistently high value for vanadium using the XRF method. Sulfur in the glass samples was measured mostly by XRF and occasionally by ion chromatography (IC). XRF results show better precision than the IC results and, based on our previous experience, greater confidence is placed in the XRF results. $\mathrm{SO}_{3}$ measurement by IC requires a glass digestion step during which loss of sulfur by volatilization is a possibility. This is probably the reason for the occasional low sulfur result measured by IC as compared to the XRF result for the same sample. 
The Catholic University of America Vitreous State Laboratory
LAW Envelope C Glass Formulation Testing

to Increase Waste Loading

Final Report, VSL-05R5900-1, Rev. 0

Compositional trends of the major and select oxides during the tests shown in Figures 5.1 - 5.3 illustrate the closeness to target and the consistency of composition over the course of the tests. Changes in glass temperature and the addition of more sugar during the last day of testing had no discernable effect on the concentration of these oxides in the discharged product. Changes at the beginning of the test, as the melt pool was turned over from the previous LAW Sub-Envelope A2 composition [54] to the LAWC100 composition, are observed as increases in sodium, aluminum, calcium, vanadium, and zinc at the expense of silicon, iron, and potassium.

Particular attention was paid to the behavior of volatile feed components such as sulfur and halides during these tests. Measured concentrations of iodine, chlorine, and sulfur in the glass product are compared to their respective target concentrations in Figures 5.4 and 5.5. Iodine and chlorine feed concentrations were constant throughout the tests at 0.1 and 0.65 wt\% on a glass basis, whereas the sulfur concentration was manipulated throughout the tests to determine the maximum incorporation amount without secondary phase formation. Iodine concentrations in the product glasses were around $0.01 \mathrm{wt} \%$ throughout the tests until the amount of sugar was increased, whereupon the iodine concentration increased to $0.04 \mathrm{wt} \%$. Previous studies have shown that iodine is not significantly retained in the glass except when processing feeds with high alkali contents $[16,18,51]$ and higher than nominal concentrations of reductants $[15,54,55]$ where iodine retention can be as high as $20 \%$ and $45 \%$, respectively. The chlorine concentration was largely unaffected by the changes in glass temperature. Changes in feed carbon concentration also had no effect on chlorine concentrations. From the perspective of incorporation into the glass melt, chlorine is not as volatile as iodine but is considerably more volatile than sulfur, as evidenced by concentrations showing wider deviations from the target. Steady-state concentrations of $\mathrm{SO}_{3}$ were attained during Tests $1,2 \mathrm{~d}$, and 2e but not in the other tests due to the formation of secondary sulfate phases on the surface of the glass pool. An indication that the feed sulfur content is higher than that which can be processed without forming secondary phases is provided by spikes in sulfur concentrations in the glass that exceed the feed concentration. The concentration of sulfur decreased during Test $2 \mathrm{e}$ as the feed carbon content was increased, in keeping with results from previous studies with LAW simulants and varying amounts of feed carbon [4, 11, 15, 54]. Sulfur retention in the LAWC100 glass during the present test is compared to sulfur retention in previous tests using LAW Sub-Envelope C2 feeds in Section 7.

\subsection{Secondary Phase Observations}

All discharged glass, and glass "dip" samples taken directly from the melt pool were closely examined to document the presence or absence of secondary phases. Glass dip samples were obtained at the beginning and end of each test to ascertain whether a secondary sulfate layer had formed on the surface of the glass melt. Table 5.4 provides a listing of all of the dip samples and whether or not a separate salt phase was evident. The first observations of secondary phases occurred near the beginning of the tests as very tiny (approximately $3 \mathrm{~mm}$ in diameter), isolated inclusions of sulfate in about ten percent of the glass discharges. Two dip samples were taken in the middle and three at the end of Test 1 , all of which indicated that there was no secondary 
The Catholic University of America Vitreous State Laboratory
LAW Envelope C Glass Formulation Testing

to Increase Waste Loading

Final Report, VSL-05R5900-1, Rev. 0

sulfate on the glass melt surface. After only about $90 \mathrm{~kg}$ of glass discharged in Test 2, substantial amounts of separated sulfate were observed in all discharge cans in Tests 2a and 2b. A picture of typical secondary sulfate phase observed during this test is shown in Figure 5.6. Secondary sulfate phases were observed in the remainder of the discharge glasses; however, the amount appeared to decrease as the feed sulfur concentration was decreased and sugar was added. The very small amount of secondary sulfate observed in most of the discharge pails from Tests $2 \mathrm{~d}$ and 2e is typified by the glass shown in Figures 5.7.a and 5.7.b. Larger amounts of secondary sulfate were observed on the surface of some discharge cans as a result of material dripping down from behind the discharge trough, as shown in Figure 5.8. This material is clearly not representative of the glass pool or bulk discharge and therefore is not an indication of secondary phase formation for this glass under normal operating conditions. Rather, it appears to be an artifact of the thinning around a seam in the bricks near the DM100-WV discharge that allows glass and/or transient sulfate migration into the discharge chamber, as described previously. Glass dip samples taken at the end of both Tests 2d and 2e indicated no secondary phases were present on the melt pool surface. In contrast, Figure 5.9 shows the appearance of a secondary sulfate phase that was observed in three of the discharge pails, which is much more typical of sulfate that has separated out of the discharged glass (rather than being simply mechanically included as in Figure 5.6). X-ray diffraction analysis of the material provided a match for a mineral containing calcium, aluminum, and sulfate. Note that this material appeared in glass samples discharged shortly after dip samples had confirmed the presence of a separate sulfate layer on the melt surface.

\subsection{Iron Redox State}

The iron oxidation states for glass samples from tests at both feed carbon contents were measured using colorimetric methods. The relatively high method detection limit of $4 \%$ divalent iron reported here is dependent on several factors but is primarily a result of the low level (1 wt\%) of $\mathrm{Fe}_{2} \mathrm{O}_{3}$ in the target glass. Sample information including name, test, and the amount of glass produced for all samples analyzed for divalent iron are given in Table 5.5. The data follow the expected trends: glass samples from tests conducted with a 0.5 stoichiometric carbon ratio had less than detectable amounts of divalent iron, whereas the test conducted at a stoichiometric carbon ratio of 0.8 produced a glass that had a considerable proportion $(30.5 \%)$ of the iron present in the divalent form. Previous tests with LAW simulants and sugar at stoichiometric ratios of 0.75 and 1.0 resulted in divalent iron concentrations of $22-30 \%$ and $24-45 \%$, respectively $[4,11,15]$, which is in general accord with the results of the present tests.

\subsection{Comparison of PCT and VHT of Crucible and Melter Glasses}

The results of the PCT and VHT procedures on a glass sample from DM100 melter testing are given in Table 5.6 along with the PCT and VHT results for two crucible glasses of the same target composition. The VHT alteration rates for the crucible and melter glasses show good agreement with each other, and are well below the contract limit of $50 \mathrm{~g} / \mathrm{m}^{2} /$ day [49]. The 
difference is much smaller than the percent relative standard deviation of $43 \%$ RSD from replicate VHT measurements on LAW glasses [48].

PCT responses (normalized mass loss in $\mathrm{g} / \mathrm{m}^{2}$ ) for the melter glass are $0.92,0.78$, and 0.14 for $\mathrm{B}, \mathrm{Na}$ and $\mathrm{Si}$, respectively. PCT responses for crucible melt sample LAWC100 of the same target composition are $0.52,0.43$, and 0.10 for $\mathrm{B}, \mathrm{Na}$, and $\mathrm{Si}$, respectively. PCT responses for the other crucible melt sample, LAWC100R1, are $0.84,0.76$, and 0.15 for $\mathrm{B}, \mathrm{Na}$, and $\mathrm{Si}$, respectively. The PCT responses for all the crucible and melter glass samples are well below the contract limit for normalized mass loss of $2.0 \mathrm{~g} / \mathrm{m}^{2}$ for B, Na, and Si [49].

The differences in PCT responses for the crucible glass sample, LAWC100R1, and melter glass sample are well below the RSD values of $27 \%, 21 \%$, and $15 \%$ for $\mathrm{B}$, $\mathrm{Na}$, and Si, respectively, from PCT round-robin testing of an Argonne National Laboratory - Low-Activity Waste Reference Material (ANL-LRM) glass [56]. The PCT responses for the other crucible glass, LAWC100, show lower values, probably due to the lower measured $\mathrm{Na}_{2} \mathrm{O}$ concentration in this sample. A recent study that compared the properties of simulant crucible, simulant melter, and actual waste crucible LAW glasses showed that there were no significant differences between the PCT and VHT responses of melter and crucible glasses of the same composition [57]. The measured $\mathrm{Na}_{2} \mathrm{O}$ concentration in one of the crucible glasses, LAWC100, was $18.14 \mathrm{wt} \%$, which was lower than the target of $20 \mathrm{wt} \%$, whereas it was closer to target at $20.49 \mathrm{wt} \%$ in the other crucible glass, LAWC100R1. The target and analyzed compositions of the melter glass, WVY-G-95A, given in Table 5.2, show an analyzed $\mathrm{Na}_{2} \mathrm{O}$ concentration of $20.29 \mathrm{wt} \%$ compared to the target of $20.00 \mathrm{wt} \%$. Thus, the results of the current tests further confirm that glasses of similar compositions have similar PCT and VHT responses and any differences in the properties can be traced to differences in compositions. The PCT and VHT responses of the LAWC100 glass and those of two old LAW Sub-Envelope C2 glasses are similar, as discussed in Section 7. 


\section{SECTION 6.0 \\ MONITORED OFF-GAS EMISSIONS}

\subsection{Particulate Sampling}

The melter exhaust was sampled for metals/particles according to 40-CFR-60 Methods 3, 5, and 29 at steady-state operating conditions during each DM100 test. The concentrations of off-gas species that are present as particulates and gaseous species that are collected in impinger solutions were derived from laboratory data on solutions extracted from air samples (filters and various solutions) together with measurements of the volume of air sampled. Particulate collection required isokinetic sampling, which entails removing gas from the exhaust at the same velocity that the air is flowing in the duct (40-CFR-60, Methods 1-5). Typically, a sample size of 30 dscf was taken at a rate of between 0.5 and $0.75 \mathrm{dscfm}$. Total particulate loading was determined by combining gravimetric analysis of the standard particle filter and chemical analysis of probe rinse solutions. An additional impinger containing $2 \mathrm{~N} \mathrm{NaOH}$ was added to the sampling train to ensure complete scrubbing of acid gases, particularly halogens. The collected materials were analyzed using direct current plasma atomic emission spectroscopy (DCP-AES) for the majority of the constituents and ion chromatography (IC) for anions. Melter emission fluxes are compared to feed fluxes in Table 6.1 where the distinction is made between constituents sampled as particles and as "gas". The "gaseous" constituents are operationally defined as those species that are scrubbed in the impinger solutions after the air stream has passed through a $0.3 \mu \mathrm{m}$ heated filter. All samples were within $10 \%$ of isokinetic.

Particulate emission rates as a percentage of feed for tests conducted at $1150^{\circ} \mathrm{C}$ and $1175^{\circ} \mathrm{C}$ were very similar, suggesting that the effect of the $25^{\circ} \mathrm{C}$ increase is within the variability of the measurements. This finding corroborates observations from previous tests, which showed that increases in particulate material did not occur until the glass melt temperature exceeded $1200^{\circ} \mathrm{C}$ [3]. As expected, the feed elements with the lowest melter decontamination factors (DF) were halogens and sulfur, followed by chromium, alkali metals, and boron. It should be noted, however, that the chromium values are likely biased high as a result of the prevalence of chromium-containing materials in the melter (K-3 and Inconel). Sulfur and chlorine emissions were predominately particulate, which is consistent with previous studies using high-alkali LAW simulants [2-4, 7, 8, 26, 29]. An exception was the sample taken during Test 2e; the additional feed sugar increased the amount of gaseous sulfur emitted, in keeping with previous tests that used carbon stoichiometeric ratios greater than 0.5 [11, 15, 54]. Iodine was almost exclusively detected in the basic impinger of the sampling train, suggesting that the emissions were mostly in the form of molecular iodine. Boron, sulfur, and the halides were the only elements detected in the impinger solutions collected downstream of the heated particle filter in the sampling train, which constitutes the "gas" fraction of the melter emissions. 
The Catholic University of America

Vitreous State Laboratory
LAW Envelope C Glass Formulation Testing

to Increase Waste Loading

Final Report, VSL-05R5900-1, Rev. 0

\subsection{Gases Monitored by FTIR}

Melter emissions were monitored in each test for a variety of gaseous components, most notably CO and nitrogen species, by Fourier Transform Infra Red Spectroscopy (FTIR). The off-gas system temperature is maintained well above $100^{\circ} \mathrm{C}$ beyond the sampling port downstream of the HEPA filter to prevent analyte loss due to condensation prior to monitoring. The FTIR was out of service for two days during Test 2 as a result of a power outage shortly after the start of Test 2 that damaged the instrument. As a result, no FTIR data are available for Test 2a and 2b. A summary of the average and the range of concentrations monitored during each test are provided in Tables 6.2 and 6.3, respectively. The concentrations of select monitored species are plotted in Figures 6.1 - 6.3. The large variations in the measured concentrations evident in these figures are a result of the pulsed feeding system and the dynamic nature of the cold cap. The analytes listed in the tables are those that were expected to be observed during the test, based on previous work; no other species were detected in the off-gas stream by FTIR. The most abundant nitrogen species monitored was NO, which is consistent with previous tests [7-18, 51-54] in which nitrates and nitrites were abundant in the feed. Measured concentrations of nitrogen oxides decreased with increasing feed carbon content in Test 2e while byproducts of organic matter decomposition such as $\mathrm{NH}_{3}, \mathrm{CO}_{2}$ and acetonitrile increased, which is also consistent with previous tests.

The results of a nitrogen mass balance are summarized in Table 6.4. In keeping with previous tests, the percent of feed nitrates and nitrites emitted as nitrogen oxides was inversely related to the amount of carbon in the feed $[11,15]$. Also, consistent with previous tests with feed at a sugar ratio of 0.5 [7-18, 51-54], about $50 \%$ of the feed nitrogen oxides was reduced to diatomic nitrogen.

\subsection{Mass Balance for Volatile Constituents}

Table 6.5 provides the percentages of sulfur, chlorine, and iodine that were retained in the glass product or identified in the various off-gas stream samples for Tests 1 and 2e. Data for other DM100 tests processing LAW high alkali simulants are included for comparison. The sulfur mass balance around the melter was excellent for both tests, with totals ranging from 98 99 percent. Closure for chlorine was not as good but within $17 \%$ for both tests. Sulfur retention in the glass ranged between 95 and 87\%, depending on the concentration of carbon in the feed. More feed sulfur was retained in the glass during the current test conducted with a carbon stoichiometric ratio 0.5 than for any of the previous tests. Emissions of sulfur were mostly in the form of particles for all tests except those conducted at stoichiometric carbon ratios greater than 0.5. About half the chlorine was retained in the glass, with the other half emitted from the melter as particles. Excess chlorine recoveries in some of the tests suggest that the feed used in the tests may have had chlorine at above the target concentration possibly due to chlorine from water used in feed preparation. Iodine retention in the glass during test conducted at the stoichiometric carbon ratio greater than 0.5 was higher ( $40 \%$ vs. $10 \%)$ than for the comparable test at the nominal stoichiometric carbon ratio. 
The Catholic University of America

Vitreous State Laboratory
LAW Envelope C Glass Formulation Testing

to Increase Waste Loading

Final Report, VSL-05R5900-1, Rev. 0

\section{SECTION 7.0 \\ COMPARISON OF TEST RESULS FOR “OLD” AND “NEW" FORMULATIONS FOR LAW SUB-ENVELOPE C2}

This section provides a summary level comparison of the test results obtained with the optimized glass formulation (LAWC100) that was developed in this work for LAW SubEnvelope C2 material and corresponding data for the current WTP baseline glass formulation for that waste (LAWC35), and its predecessor (LAWC31).

The composition of the new glass composition, LAWC100, is compared to compositions of two old LAW Sub-Envelope C2 glasses in Table 7.1. Compared to the old glasses, LAW C100 has lower $\mathrm{Fe}_{2} \mathrm{O}_{3}$ and $\mathrm{SiO}_{2}$ contents and higher $\mathrm{B}_{2} \mathrm{O}_{3}$ content. LAWC100 contains 1 wt\% of $\mathrm{V}_{2} \mathrm{O}_{5}$ which is not present in the old glasses. $\mathrm{CaO}$, which is beneficial in improving sulfate solubility, is maintained at a high concentration in LAWC100. However, $\mathrm{Li}_{2} \mathrm{O}$, another component that is highly beneficial in improving sulfate solubility in the glasses, was not added to LAWC100 because of the already high alkali content from incorporation of $20 \mathrm{wt} \%$ of $\mathrm{Na}_{2} \mathrm{O}$ from the LAW waste stream. Properties such as electrical conductivity, PCT, and VHT are similar for all three glasses. The viscosities of LAWC100 and one of the old glasses (LAWC35) are similar, whereas the other old glass (LAWC31) has somewhat higher viscosity. In combination, the composition changes (particularly the higher calcium, inclusion of vanadium, higher boron, lower silicon and lower iron) lead to increased sulfur solubility, increased incorporation rate, and reduced tendency to form a separate sulfate phase during processing. The higher sulfate solubility allows higher waste loading in LAWC100 glass, which results in $20 \mathrm{wt} \% \mathrm{Na}_{2} \mathrm{O}$ in LAWC100 glass as compared to about $11.9 \mathrm{wt} \% \mathrm{Na}_{2} \mathrm{O}$ in the old LAW Sub-Envelope C2 glasses.

Glass production rates measured during the current test along with those measured during previous LAW Sub-Envelope C2 tests on the DM100 and LAW Pilot Melter are given in Table 7.1. The bubbling rates for the DM100 test are also given in Table 7.1. All LAW Pilot Melter tests were conducted at a bubbling rate of about $170 \mathrm{lpm}\left(51.5 \mathrm{lpm} / \mathrm{m}^{2}\right)$. The three LAW Sub-Envelope C2 feeds were processed in the DM100 at similar rates, even though the bubbling rate needed was somewhat lower for one of the old feeds. The two old LAW Sub-Envelope C2 feeds processed at about the same rate in the LAW Pilot Melter. The DM100 can be used to determine differences in the processing rates of different feed formulations, and the effect of variables such as temperature on processing rates when the relevant tests are conducted sequentially over a short time period. Since the DM100 has only one bubbler, the age of the bubbler, or small differences in the bubbler orientation can occasionally result in differences in the bubbling rate required to achieve a target glass production rate, and it becomes difficult to determine the exact reason for these differences, especially when the tests are conducted over a long period of time. Therefore, in this case, it is better to use the LAW Pilot Melter data to predict the glass production rate for the WTP melter while processing the LAW Sub-Envelope C2 feed. Based on the LAW Pilot melter data [26, 30], at an operating temperature of $1150^{\circ} \mathrm{C}$, 
we would expect the new LAW Sub-Envelope C2 feed to process at a rate of about 21 to $22 \mathrm{MT}$ of glass per day per WTP LAW melter.

Sulfur retention in the LAWC100 glass during the present test is compared to sulfur retention in previous tests using LAW Sub-Envelope C2 feeds in Table 7.1. The sulfur retentions were similar (95\% and 91\%, respectively) for the present test and one of the old tests using LAWC31 feed [15], and somewhat lower (79\%) for the previous test using LAWC35 feed [18]. The higher sulfur retention in the new formulation is likely a result of the higher alkali content. The higher alkali content is made possible as a result of the ability to incorporate higher sulfate, which allows increased waste loading. The lower sulfur retention in LAWC35 as compared to LAWC31 (which has the same sodium content), is likely a result of its higher sulfate (and halide) content. 
The Catholic University of America

Vitreous State Laboratory
LAW Envelope C Glass Formulation Testing

to Increase Waste Loading

Final Report, VSL-05R5900-1, Rev. 0

\section{SECTION 8.0 \\ SUMMARY AND CONCLUSIONS}

Several tests were conducted on the DM10 and DM100 vitrification systems to assess the effectiveness of a new glass formulation for LAW Envelope $C$ simulants in incorporating high levels of sulfur without the formation of secondary phases. The glass formulation for the melter tests was selected on the basis of earlier work with LAW Envelope A simulants and a series of crucibles melts that were prepared and characterized. The results of those tests led to the selection of the LAWC100 formulation, which contains $20 \% \mathrm{Na}_{2} \mathrm{O}$ and which showed the potential for high sulfate incorporation, and met all of the WTP product quality and processability requirements.

DM10 melter screening tests were conducted at three different glass temperatures, $1150^{\circ} \mathrm{C}, 1175^{\circ} \mathrm{C}$, and $1200^{\circ} \mathrm{C}$, to determine the maximum amount of feed sulfur that can be processed without forming secondary sulfate phases. Based on these results, feed sulfur concentrations of 1.1 and $1.3 \mathrm{wt} \% \mathrm{SO}_{3}$ on a glass basis were selected for further testing on the DM100 melter at temperatures of $1150^{\circ} \mathrm{C}$ and $1175^{\circ} \mathrm{C}$, respectively. Testing conducted at $1150^{\circ} \mathrm{C}$ with the LAW Envelope $\mathrm{C}$ feed at an $\mathrm{SO}_{3}$ concentration of $1.1 \mathrm{wt} \%$ was successful at retaining $95 \%$ of the feed sulfur in the glass product without the formation of a separate sulfate phase on the melt pool surface. At $1175^{\circ} \mathrm{C}$, feed with a sulfur concentration of $1.15 \mathrm{wt} \% \mathrm{SO}_{3}$ on a glass basis was processed successfully without the formation of a sulfate phase on the melt surface. An additional test was conducted at $1175^{\circ} \mathrm{C}$ and a higher feed sugar content, which was also successful at processing feed with a sulfur concentration of $1.15 \mathrm{wt} \% \mathrm{SO}_{3}$ on a glass basis without the formation of a separate sulfate phase on the melt pool surface but with somewhat lower retention of sulfur in the glass. A sample of the product glass from the end of Test 1 was subjected to the PCT and VHT procedures, both of which confirmed responses well below the respective WTP contract limits, as expected based on the PCT and VHT results for the corresponding crucible melt glasses.

Composition and properties of the LAWC100 glass are compared to those of two old LAW Sub-Envelope C2 glasses in Table 7.1. LAWC100, due to its much higher sulfur solubility, has a higher waste loading as compared to the old glasses. As is evident from the table, the other properties of LAWC100 are similar to those of the old glasses. Since the properties of the glasses are similar, LAWC100 was expected to process at a rate comparable to that of the old glasses, and this expectation was validated in DM100 tests. Based on the processing rates of the old LAW Sub-Envelope C2 glasses in the LAW Pilot Melter, we expect that the new LAWC100 glass will process at a rate of about 21 to 22 MT glass per day per WTP melter.

Total particulate and gaseous emissions from the melter were sampled for two tests. Melter DFs were determined for each element in the feed for two of the DM100 tests that were performed. Increases in reductant concentrations resulted in increased gaseous sulfur emissions but had little effect on other volatile elements such as chlorine. Good mass balance closure 
The Catholic University of America Vitreous State Laboratory
LAW Envelope C Glass Formulation Testing to Increase Waste Loading Final Report, VSL-05R5900-1, Rev. 0

around the melter was achieved for sulfur and chlorine. Iodine retention in the glass increased by a factor of four as the stoichiometric carbon ratio increased from 0.5 to 0.8 .

In conclusion, the results of this work confirmed that in DM100-scale melter tests the new formulation for LAW Envelope $\mathrm{C}$ waste, with $20 \mathrm{wt} \% \mathrm{Na}_{2} \mathrm{O}$, is able to incorporate $1.1 \mathrm{wt} \%$ $\mathrm{SO}_{3}$ at $1150^{\circ} \mathrm{C}$ and $1.15 \mathrm{wt} \% \mathrm{SO}_{3}$ at $1175^{\circ} \mathrm{C}$, both on a glass basis, without the formation of a separate sulfate phase while producing glass products that meet all of the WTP product quality and processability requirements. 


\section{SECTION 9.0}

REFERENCES

[1] LAW Pilot Melter Decommissioning and Testing, Letter Subcontract \#DE-AC2703RV14539.

[2] "Glass Formulation Testing to Increase Sulfate Incorporation,” K.S. Matlack, M. Chaudhuri, H. Gan, I.S. Muller, W. Gong, and I.L. Pegg, VSL-04R4960-1, Rev. 0, Vitreous State Laboratory, The Catholic University of America, Washington, DC, 2/28/05.

[3] "Small Scale Melter Testing to Assess Impact of Higher Temperature Melter Operations,” K.S. Matlack, W. Gong, and I.L. Pegg, VSL-04R4980-1, Rev. 0, Vitreous State Laboratory, The Catholic University of America, Washington, DC, 2/13/04.

[4] "Glass Formulation Testing to Increase Sulfate Volatilization from Melter," K.S. Matlack, W. Gong, and I.L. Pegg, VSL-04R4970-1, Rev. 0, Vitreous State Laboratory, The Catholic University of America, Washington, DC, 2/24/05.

[5] "Summary of Preliminary Results on Enhanced Sulfate Incorporation During Vitrification of LAW Feeds", I.L. Pegg, H. Gan, I.S. Muller, D.A. McKeown, and K.S. Matlack, VSL-00R3630-1, Vitreous State Laboratory, The Catholic University of America, Washington, DC, 4/5/2000.

[6] "Sulfur Incorporation in Waste Glass Melts of Various Compositions," W.K. Kot, H. Gan, and I.L. Pegg, Ceramic Transactions, Vol. 107, pp. 441, Eds. G.T. Chandler and X. Feng, American Ceramic Society, 2000.

[7] "Melter Tests with LAW Envelope B Simulants to Support Enhanced Sulfate Incorporation,” K.S. Matlack, S.P. Morgan, and I.L. Pegg, VSL-00R3501-1, Rev. 0, Vitreous State Laboratory, The Catholic University of America, Washington, D.C., $11 / 27 / 00$.

[8] "Melter Tests with LAW Envelope A and C Simulants to Support Enhanced Sulfate Incorporation,” K.S. Matlack, S.P. Morgan, and I.L. Pegg, VSL-01R3501-2, Rev. 0, Vitreous State Laboratory, The Catholic University of America, Washington, D.C., $1 / 26 / 01$.

[9] "Compositional Variation Tests on DuraMelter 100 with LAW Sub-Envelope A1 Feed (LAWA44 Glass) in Support of the LAW Pilot Melter," K.S. Matlack, W. Gong, and I.L. Pegg, VSL-02R62N0-4, Rev. 0, Vitreous State Laboratory, The Catholic University of America, Washington, D.C., 6/18/02. 
[10] “Compositional Variation Tests on DuraMelter 100 with LAW Sub-Envelope A2 Feed (LAWA88) Glass in Support of the LAW Pilot Melter,” K. S. Matlack, W. Gong and I.L. Pegg, VSL-02R62N0-3, Rev. 0, Vitreous State Laboratory, The Catholic University of America, Washington, D.C., 11/1/02.

[11] "Compositional Variation Tests on DuraMelter 100 with LAW Sub-Envelope A3 Feed in Support of the LAW Pilot Melter," K.S. Matlack, W. Gong, and I.L. Pegg, VSL01R62N0-1, Rev. 1, Vitreous State Laboratory, The Catholic University of America, Washington, D.C., 7/15/02.

[12] "Compositional Variation Tests on DuraMelter 100 with LAW Sub-Envelope B1 Feed in Support of the LAW Pilot Melter," K.S. Matlack, W. Gong, and I.L. Pegg, VSL02R62N0-5, Rev. 0, Vitreous State Laboratory, The Catholic University of America, Washington, D.C., 5/8/03.

[13] "Compositional Variation Tests on DuraMelter 100 with LAW Sub-Envelope B2 Feed in Support of the LAW Pilot Melter,” K.S. Matlack and I.L. Pegg, VSL-03R3410-2, Rev. 0, The Catholic University of America, Vitreous State Laboratory, Washington, D.C., 10/20/03.

[14] “Compositional Variation Tests on DuraMelter 100 with LAW Sub-Envelope C1 Feed (LAWC22 Glass) in Support of the LAW Pilot Melter,” K.S. Matlack, W. Gong, and I.L. Pegg, VSL-02R62N0-2, Rev. 1, Vitreous State Laboratory, The Catholic University of America, Washington, D.C., 9/23/02.

[15] “Compositional Variation Tests on DuraMelter 100 with LAW Sub-Envelope C2 Feed in Support of the LAW Pilot Melter,” K.S. Matlack, W. Gong, R.A. Callow and I.L. Pegg, VSL-04R4410-1, Rev. 0, Vitreous State Laboratory, The Catholic University of America, Washington, DC, 6/17/04.

[16] "DuraMelter 100 Sub-Envelope Changeover Testing Using LAW Sub-Envelope A1 and C1 Feeds in Support of the LAW Pilot Melter,” K.S. Matlack, W. Gong, and I.L. Pegg, VSL-02R62N0-6, Rev. 0, Vitreous State Laboratory, The Catholic University of America, Washington, D.C., 9/9/03.

[17] "DuraMelter 100 Sub-Envelope Changeover Testing Using LAW Sub-Envelope A2 and B1 Feeds in Support of the LAW Pilot Melter,” K.S. Matlack, W. Gong, and I.L. Pegg, VSL-03R3410-1, Rev. 0, Vitreous State Laboratory, The Catholic University of America, Washington, D.C., 8/22/03.

[18] "DuraMelter 100 Sub-Envelope Changeover Testing Using LAW Sub-Envelope A3 and C2 Feeds in Support of the LAW Pilot Melter,” K.S. Matlack, W. Gong, and I.L. Pegg, VSL-03R3410-3, Rev. 0, Vitreous State Laboratory, The Catholic University of America, Washington, D.C., 10/17/03. 
[19] “RPP-WTP Pilot Melter Envelope B Throughput Test Results Report,” TRR-PLT-57, Duratek, Inc., Columbia, MD, 10/13/00.

[20] “RPP-WTP Pilot Melter Envelope A and C Throughput Test Results Report,” TRR-PLT54, Duratek, Inc., Columbia, MD, 10/13/00.

[21] “RPP-WTP Pilot Melter Sub-Envelope A1 Variation Test Results Report,” TRR-PLT071, Rev.0, Duratek, Inc., Columbia, MD, 4/28/03.

[22] “RPP-WTP Pilot Melter Sub-Envelope C1-A1 Changeover Test Results Report,” TRRPLT-035, Rev.0, Duratek, Inc., Columbia, MD, 9/29/03.

[23] “RPP-WTP Pilot Melter Sub-Envelope A2 Variation Test Results Report,” TRR-PLT070, Rev.0, Duratek, Inc., Columbia, MD, 10/4/02.

[24] “RPP-WTP Pilot Melter Sub-Envelope A2-B1 Changeover Test Results Report,” TRRPLT-078, Rev.0, Duratek, Inc., Columbia, MD, 11/3/03.

[25] “RPP-WTP Pilot Melter Sub-Envelope A3 Variation Test Results Report,” TRR-PLT060, Rev.2, Duratek, Inc., Columbia, MD, 11/19/02.

[26] “RPP-WTP Pilot Melter Sub-Envelope C2-A3 Changeover Test Results Report,” TRRPLT-079, Rev.0, Duratek, Inc., Columbia, MD, 11/11/03.

[27] “RPP-WTP Pilot Melter Sub-Envelope B1 Variation Test Results Report,” TRR-PLT074, Rev.0, Duratek, Inc., Columbia, MD, 8/26/03.

[28] “RPP-WTP Pilot Melter Sub-Envelope B2 Variation Test Results Report,” TRR-PLT073, Rev.0, Duratek, Inc., Columbia, MD, 10/27/03.

[29] “RPP-WTP Pilot Melter Sub-Envelope C1 Variation Test Results Report,” TRR-PLT069, Rev.2, Duratek, Inc., Columbia, MD, 2/6/03.

[30] “RPP-WTP Pilot Melter Sub-Envelope C2 Variation Test Results Report,” TRR-PLT072, Rev.1, Duratek, Inc., Columbia, MD, 3/12/03.

[31] “LAW Glass Formulation Testing to Increase Waste Loading,” K.S. Matlack, H. Gan, I.S. Muller, and I.L. Pegg, VSL-05T5900-1, Rev. 0, Vitreous State Laboratory, The Catholic University of America, Washington, DC, April 7, 2005.

[32] “Glass Formulation and Testing with TWRS LAW Simulants,” I.S. Muller and I.L. Pegg, Vitreous State Laboratory, The Catholic University of America, Washington, DC, January 16, 1998. 
[33] "Glass Formulation And Testing With RPP-WTP LAW Simulants," I.S. Muller, A.C. Buechele, and I.L. Pegg, Final Report, VSL-01R3560-2, Vitreous State Laboratory, The Catholic University of America, Washington, DC, February 23, 2001.

[34] "Baseline LAW Glass Formulation Testing,” I.S. Muller and I.L. Pegg, VSL-03R3460-1, Rev.0, Vitreous State Laboratory, The Catholic University of America, Washington, DC, August 8, 2003.

[35] “Glass Formulations to Support Melter Testing”, I.S. Muller and I.L. Pegg, VSL03R3460-2, Rev.0, Vitreous State Laboratory, The Catholic University of America, Washington, DC, 2/6/04.

[36] “Quality Assurance Project Plan for RPP-WTP Support Activities Conducted by VSL," Vitreous State Laboratory, QAPP Rev. 8, Vitreous State Laboratory, The Catholic University of America, Washington, DC, 6/2/05.

[37] "Master List of Controlled VSL Manuals and Standard Operating Procedures in Use," QA-MLCP, Rev. 15, Vitreous State Laboratory, The Catholic University of America, Washington, DC, 6/6/05.

[38] "LAW Pilot Melter and DM-100 Sub-Envelope Changeover Testing," E.V. Morrey, WTP Test Specification, 24590-LAW-TSP-RT-02-012, Rev. 0.

[39] “Tank Farm Contractor Operation and Utilization Plan,” R.A. Kirkbride, et al., CH2M Hill Hanford Group Inc., Richland, WA, HNF-SD-SP-012, Rev. 3, 10/2/01.

[40] “Basis of Design,” BNFL report, DB-W375-EG00001, Rev. 0, November 23, 1998.

[41] "Physical and Rheological Properties of Waste Simulants and Melter Feeds for RPPWTP LAW Vitrification,” Final Report, I.S. Muller, H. Gan, and I.L. Pegg, VSL00R3520-1, Rev. 0, Vitreous State Laboratory, The Catholic University of America, Washington, DC, 1/16/01.

[42] “Characterization of Simulated WTP LAW Melter Feeds," Final Report, H. Zhao, I.S. Muller, and I.L. Pegg, VSL-04R4500-1, Rev. 0, Vitreous State Laboratory, The Catholic University of America, Washington, DC, 5/26/04.

[43] "Raman Studies of Sulfur in Borosilicate Waste Glasses: Sulfate Environments," D.A. McKeown, I.S. Muller, H. Gan, I.L. Pegg, and C.A. Kendziora, J. Non-Crystalline Solids, v. 288, p. 191-199 (2001). 
[44] "X-ray Absorption Studies of Vanadium Valence and Local Environment in Borosilicate Waste Glasses," D.A. McKeown, I.S. Muller, K.S. Matlack, and I.L. Pegg, Scientific Basis for Nuclear Waste Management XXV, Materials Research Society, 713, 547, (2002).

[45] "X-ray Absorption Studies of Vanadium Valence and Local Environment in Borosilicate Waste Glasses using Vanadium Sulfide, Silicate, and Oxide Standards," D.A. McKeown, I.S. Muller, K.S. Matlack, and I.L. Pegg, J. Non-Crystalline Solids, v. 298, p. 160-175 (2002).

[46] "Determination of Sulfur Environments in Borosilicate Waste Glasses Using X-ray Absorption Near-Edge Spectroscopy," D.A. McKeown, I.S. Muller, H. Gan, I.L. Pegg, and W.C. Stolte, J. Non-Crystalline Solids, 333, 74 (2004).

[47] "Results of Melter Tests Using TWRS LAW Envelope C Simulants," K.S. Matlack, I.S. Muller, and I.L. Pegg, Final Report, Vitreous State Laboratory, The Catholic University of America, Washington, DC, 8/7/97.

[48] "Phase 1 ILAW PCT and VHT Model Development,” I.S. Muller, H. Gan and I.L. Pegg, VSL-04R4480-2, Rev. 0, Vitreous State Laboratory, Washington, D.C., 2/8/05.

[49] Bechtel National, Inc. Design, Construction, and Commissioning of the Hanford Tank Waste Treatment and Immobilization Plant Contract Number: DE-AC27-01RV14136, 8/31/00.

[50] "Development of LAW and HLW Vitrification Physical Property Bounding Conditions and Simulant Verification Criteria," A. Poloski, H. Smith, G. Smith, and B. Calloway, WTP-RPT-075, Rev. 0, 2/03.

[51] "Integrated Off-Gas System Tests on the DM1200 Melter with RPP-WTP LAW SubEnvelope A1 Simulants,” K.S. Matlack, W. Gong, T. Bardakci, N. D’Angelo, and I.L. Pegg, VSL-02R8800-2, Rev. 0, Vitreous State Laboratory, The Catholic University of America, Washington, DC, 9/03/02.

[52] "Integrated Off-Gas System Tests on the DM1200 Melter with RPP-WTP LAW SubEnvelope C1 Simulants,” K.S. Matlack, W. Gong, T. Bardakci, D’Angelo, and I.L. Pegg, VSL-02R8800-1, Rev. 0, 7/25/02.

[53] "Regulatory Off-Gas Emissions Testing on the DM1200 Melter System Using HLW and LAW Simulants,” K. S. Matlack, W. Gong, T. Bardakci, N. D'Angelo, M. Brandys, W. Kot, and I. L. Pegg, Final Report, VSL-05R5830-1, Rev. A, 8/15/05. 
The Catholic University of America

Vitreous State Laboratory
LAW Envelope C Glass Formulation Testing to Increase Waste Loading Final Report, VSL-05R5900-1, Rev. 0

[54] "DuraMelter100 Tests with AP-101/AY-102 Blended Feed from the Semi-Integrated Pilot Plant," K. S. Matlack, W. Gong, and I. L. Pegg, VSL-05R5410-1, Rev. 0, 2/24/05.

[55] "Integrated DM1200 Melter of Redox Effects Using HLW AZ-101 and C-106/AY-102 Simulants,” K.S. Matlack, W. Gong, T. Bardakci, N. D’Angelo, W. Lutze, P.M. Bizot, R.A. Callow, M. Brandys, W.K. Kot and I.L. Pegg, VSL-04R4800-1, Rev. 0, 5/6/04.

[56] "Round Robin Testing of a Reference Glass for Low-Activity Waste Forms," W.L. Ebert and S.F. Wolf, Department of Energy report ANL-99/22, Argonne National Laboratory, Argonne, IL, 1999.

[57] “Comparison of LAW Simulant, Actual Waste, and Melter Glasses,” I.S. Muller, I. Joseph, and I.L. Pegg, VSL-05R5460-1, Rev. 0, Vitreous State Laboratory, Washington, D.C., $7 / 18 / 05$. 
Table 2.1. LAW Envelope C (AN-102) Waste Simulant Recipe at 8 Molar Sodium.

\begin{tabular}{|c|c|c|c|c|c|c|c|c|c|}
\hline \multirow{2}{*}{$\begin{array}{c}\text { Envelope } \\
\text { Constituents } \\
-\end{array}$} & \multicolumn{2}{|c|}{$\begin{array}{c}\text { Simulant AN-102 } \\
\text { Including Pretreatment }\end{array}$} & \multirow{2}{*}{$\begin{array}{c}\text { Glass } \\
\text { Oxides }\end{array}$} & \multirow{2}{*}{$\begin{array}{c}\text { AN-102 } \\
\text { Simulant as } \\
\text { Oxides (wt\%) }\end{array}$} & Source in Simulant & \multirow[t]{2}{*}{$\begin{array}{l}\text { Order for } \\
\text { Addition }\end{array}$} & \multirow[t]{2}{*}{$\begin{array}{c}\text { Formula } \\
\text { Weight }\end{array}$} & \multirow{2}{*}{$\begin{array}{l}\text { Assay* } \\
\text { d below }\end{array}$} & \multirow[t]{2}{*}{$\begin{array}{c}\text { Target } \\
\text { Weight (g) }\end{array}$} \\
\hline & $\mathrm{mg} / \mathrm{L}$ & Molarity & & & In $498.75 \mathrm{ml}$ water add fo & & & & \\
\hline $\mathrm{Al}$ & 9922 & 0.368 & $\mathrm{Al}_{2} \mathrm{O}_{3}$ & 6.380 & $\mathrm{Al}\left(\mathrm{NO}_{3}\right)_{3} \cdot 9 \mathrm{H}_{2} \mathrm{O}, 60 \%$ sol. & 1 & 375.14 & 0.61 & 227.31 \\
\hline $\mathrm{B}$ & 30 & 0.003 & $\mathrm{~B}_{2} \mathrm{O}_{3}$ & 0.032 & H3BO3 & 4 & 61.83 & 0.99 & 0.17 \\
\hline $\mathrm{Ca}$ & 396 & 0.010 & $\mathrm{CaO}$ & 0.189 & $\mathrm{Ca}\left(\mathrm{NO}_{3}\right)_{2} * 4 \mathrm{H}_{2} \mathrm{O}$ & 2 & 236.16 & 0.99 & 2.36 \\
\hline $\mathrm{Cr}$ & 174 & 0.003 & $\mathrm{Cr}_{2} \mathrm{O}_{3}$ & 0.086 & $\mathrm{Na}_{2} \mathrm{CrO}_{4} * 4 \mathrm{H}_{2} \mathrm{O}$ & 7 & 234.04 & 0.99 & 0.79 \\
\hline $\mathrm{K}$ & 1604 & 0.041 & $\mathrm{~K} 2 \mathrm{O}$ & 0.657 & $\mathrm{KOH}$ & 6 & 56.10 & 0.91 & 2.53 \\
\hline $\mathrm{Na}$ & 183920 & 8.000 & $\mathrm{Na} 2 \mathrm{O}$ & 84.371 & $\mathrm{NaOH}, 50 \%$ sol. $\mathrm{D}=1.53$ & 5 & 40.00 & 0.50 & 152.54 \\
\hline $\mathrm{Ni}$ & 337 & 0.006 & $\mathrm{NiO}$ & 0.146 & $\mathrm{Ni}\left(\mathrm{NO}_{3}\right)_{2} * 6 \mathrm{H}_{2} \mathrm{O}$ & 3 & 290.81 & 1.00 & 1.67 \\
\hline $\mathrm{Pb}$ & 150 & 0.000 & $\mathrm{PbO}$ & 0.055 & $\mathrm{PbO}$ & 8 & 223.20 & 1.00 & 0.16 \\
\hline $\mathrm{Si}$ & 73 & 0.003 & $\mathrm{SiO}_{2}$ & 0.053 & $\mathrm{SiO}_{2}$ & 9 & 60.09 & 0.99 & 0.16 \\
\hline $\mathrm{Cl}$ & 8237 & 0.232 & $\mathrm{Cl}$ & 2.803 & $\mathrm{NaCl}$ & 10 & 58.45 & 0.99 & 13.72 \\
\hline $\mathrm{F}$ & 2410 & 0.127 & $\mathrm{~F}$ & 0.820 & $\mathrm{NaF}$ & 11 & 42.00 & 0.99 & 5.38 \\
\hline $\mathrm{NO}_{2}$ & 69129 & 1.503 & $\mathrm{NO}_{2}$ & - & $\mathrm{NaNO}_{2}$ & 19 & 69.00 & 1.00 & 104.21 \\
\hline $\mathrm{NO}_{3}$ & 178997 & 2.887 & $\mathrm{NO}_{3}$ & - & $\mathrm{NaNO}_{3}$ & 20 & 84.99 & 0.99 & 149.84 \\
\hline $\mathrm{CO}_{3}$ & 44356 & 0.739 & $\mathrm{CO}_{3}$ & - & $\mathrm{Na}_{2} \mathrm{CO}_{3}$ & 21 & 105.99 & 1.00 & 78.34 \\
\hline $\mathrm{NH}_{3}$ & 123 & 0.007 & $\mathrm{NH}_{3}$ & - & $\mathrm{NH}_{4} \mathrm{NO}_{3}$ & 18 & 80.04 & 1.00 & 0.58 \\
\hline Org.Carbon & 23569 & 1.965 & - & - & - & - & - & - & - \\
\hline Formate & 26113 & 0.580 & - & - & Sodium Formate (C1) & 14 & 68.01 & 0.99 & 39.85 \\
\hline Oxalate & 1501 & 0.017 & - & - & Sodium Oxalate (C2) & 15 & 134.00 & 0.99 & 2.31 \\
\hline Glycolate & 34273 & 0.451 & - & - & Glycolic Acid (C2) & 16 & 76.05 & 0.71 & 48.34 \\
\hline Citric Acid & 14362 & 0.075 & - & - & Citric Acid (C6) & 17 & 192.12 & 0.99 & 14.51 \\
\hline - & - & - & SUM & 100.00 & & ılant Weigh & & & 1378.92 \\
\hline
\end{tabular}

- Empty data field.

* Assay refers to the purity of the raw material as specified by the vendor.

$\$$ Simulant formulated to provide a concentration of $0.75 \mathrm{wt} \% \mathrm{SO}_{3}$ in glass; additional $\mathrm{Na}_{2} \mathrm{SO}_{4}$ or $\mathrm{NaOH}$ added as needed at VSL. 
Table 2.2. Target and Analyzed Compositions of Four New LAW Envelope C Crucible Glasses (wt \%).

\begin{tabular}{|c|c|c|c|c|c|c|c|c|c|c|}
\hline Glass ID & \multicolumn{2}{|c|}{ LAWC100 } & \multicolumn{2}{|c|}{ LAWC100R1 $^{* *}$} & \multicolumn{2}{|c|}{ LAWC101 } & \multicolumn{2}{|c|}{ LAWC102 } & \multicolumn{2}{|c|}{ LAWC103 } \\
\hline Loading & \multicolumn{2}{|c|}{$24.06 \%$} & \multicolumn{2}{|c|}{$24.06 \%$} & \multicolumn{2}{|c|}{$24.06 \%$} & \multicolumn{2}{|c|}{$24.06 \%$} & \multicolumn{2}{|c|}{$24.06 \%$} \\
\hline Component & Target & Analyzed* & Target & Analyzed ${ }^{*}$ & Target & Analyzed $^{*}$ & Target & Analyzed ${ }^{*}$ & Target & Analyzed ${ }^{*}$ \\
\hline $\mathrm{Al}_{2} \mathrm{O}_{3}$ & 10.16 & 10.42 & 10.16 & 10.06 & 10.16 & 10.39 & 8.64 & 8.68 & 7.12 & 7.39 \\
\hline $\mathrm{B}_{2} \mathrm{O}_{3}$ & 13.68 & 13.68 & 13.68 & $13.68^{\#}$ & 13.00 & 13.13 & 13.68 & 13.89 & 13.68 & 14.16 \\
\hline $\mathrm{CaO}$ & 8.02 & 7.81 & 8.02 & 7.62 & 8.02 & 7.94 & 8.02 & 8.17 & 8.02 & 8.13 \\
\hline $\mathrm{Cr}_{2} \mathrm{O}_{3}$ & 0.02 & 0.04 & 0.02 & 0.03 & 0.02 & 0.02 & 0.02 & 0.03 & 0.02 & 0.02 \\
\hline $\mathrm{Fe}_{2} \mathrm{O}_{3}$ & 1.00 & 1.08 & 1.00 & 1.03 & 1.00 & 1.12 & 1.00 & 1.13 & 1.00 & 1.08 \\
\hline $\mathrm{K}_{2} \mathrm{O}$ & 0.15 & 0.27 & 0.15 & 0.26 & 0.15 & 0.26 & 0.15 & 0.28 & 0.15 & 0.26 \\
\hline $\mathrm{MgO}$ & 1.00 & 1.06 & 1.00 & 0.95 & 1.00 & 0.96 & 1.00 & 0.92 & 1.00 & 0.90 \\
\hline $\mathrm{Na}_{2} \mathrm{O}$ & 20.00 & 18.14 & 20.00 & 20.49 & 20.00 & 20.03 & 20.00 & 19.53 & 20.00 & 19.35 \\
\hline $\mathrm{NiO}$ & 0.03 & 0.00 & 0.03 & 0.01 & 0.03 & 0.01 & 0.03 & 0.02 & 0.03 & 0.02 \\
\hline $\mathrm{PbO}$ & 0.01 & 0.25 & 0.01 & 0.01 & 0.01 & 0.02 & 0.01 & 0.01 & 0.01 & 0.02 \\
\hline $\mathrm{SiO}_{2}$ & 36.62 & 38.81 & 36.62 & 36.88 & 36.62 & 36.59 & 36.62 & 36.31 & 36.62 & 37.00 \\
\hline $\mathrm{V}_{2} \mathrm{O}_{5}$ & 1.00 & 1.17 & 1.00 & 1.15 & 1.00 & 1.21 & 1.00 & 1.23 & 1.00 & 1.22 \\
\hline $\mathrm{ZnO}$ & 3.00 & 2.86 & 3.00 & 2.81 & 3.00 & 2.98 & 3.00 & 3.00 & 3.00 & 2.89 \\
\hline $\mathrm{ZrO}_{2}$ & 3.00 & 3.10 & 3.00 & 3.16 & 3.68 & 3.70 & 4.52 & 4.98 & 6.04 & 6.34 \\
\hline $\mathrm{Cl}$ & 0.65 & 0.56 & 0.65 & 0.51 & 0.65 & 0.53 & 0.65 & 0.54 & 0.65 & 0.23 \\
\hline $\mathrm{F}$ & 0.19 & NA & 0.19 & NA & 0.19 & NA & 0.19 & NA & 0.19 & NA \\
\hline $\mathrm{P}_{2} \mathrm{O}_{5}$ & 0.27 & 0.34 & 0.27 & 0.31 & 0.27 & 0.35 & 0.27 & 0.34 & 0.27 & 0.34 \\
\hline $\mathrm{SO}_{3}$ & 1.20 & 0.77 & 1.20 & 0.94 & 1.20 & 0.89 & 1.20 & 1.00 & 1.20 & 0.87 \\
\hline SUM & 100.0 & 100.4 & 100.0 & 99.9 & 100.0 & 100.1 & 100.0 & 100.1 & 100.0 & 100.2 \\
\hline
\end{tabular}

* Analyzed by X-ray fluorescence except for boron which was measured by DCP

** LAWC100R1 is a remelt of LAWC100

\# Target composition

NA - Not analyzed 
Table 2.3. Measured Compositions of Four New LAW Envelope C Crucible Glasses Remelted with 4 wt\% Excess $\mathrm{SO}_{3}$ (wt\%).

\begin{tabular}{|c|c|c|c|c|c|c|c|c|c|c|c|c|}
\hline \multirow[b]{2}{*}{ Component } & \multicolumn{3}{|c|}{ LAWC100S2 } & \multicolumn{3}{|c|}{ LAWC101S2 } & \multicolumn{3}{|c|}{ LAWC102S2 } & \multicolumn{3}{|c|}{ LAWC103S2 } \\
\hline & $\mathrm{XRF}$ & $\begin{array}{c}\text { XRF } \\
\text { after } \\
\text { washing }\end{array}$ & $\mathrm{DCP}$ & $\mathrm{XRF}$ & $\begin{array}{c}\text { XRF } \\
\text { after } \\
\text { washing }\end{array}$ & $\mathrm{DCP}$ & $\mathrm{XRF}$ & $\begin{array}{c}\text { XRF } \\
\text { after } \\
\text { washing }\end{array}$ & $\mathrm{DCP}$ & $\mathrm{XRF}$ & $\begin{array}{c}\text { XRF } \\
\text { after } \\
\text { washing }\end{array}$ & DCP \\
\hline $\mathrm{Al}_{2} \mathrm{O}_{3}$ & 10.66 & 11.08 & 9.73 & 10.63 & 10.77 & 9.8 & 9.03 & 9.18 & 8.2 & 7.38 & 7.54 & 6.78 \\
\hline $\mathrm{B}_{2} \mathrm{O}_{3}$ & $\mathrm{NA}^{*}$ & $\mathrm{NA}^{*}$ & 13.97 & $\mathrm{NA}^{*}$ & NA* & 13.53 & $\mathrm{NA}^{*}$ & $\mathrm{NA}^{*}$ & 14.12 & $\mathrm{NA}^{*}$ & $\mathrm{NA}^{*}$ & 14.09 \\
\hline $\mathrm{CaO}$ & 7.66 & 7.83 & 7.23 & 7.77 & 7.83 & 7.38 & 7.93 & 7.99 & 7.23 & 7.82 & 8.17 & 7.31 \\
\hline $\mathrm{Cr}_{2} \mathrm{O}_{3}$ & 0.03 & 0.03 & 0.03 & 0.03 & 0.03 & 0.03 & 0.02 & 0.01 & 0.02 & 0.02 & 0.02 & 0.02 \\
\hline $\mathrm{Fe}_{2} \mathrm{O}_{3}$ & 1.08 & 1.11 & 1.13 & 1.07 & 1.10 & 1.15 & 1.09 & 1.12 & 1.16 & 1.08 & 1.17 & 1.16 \\
\hline $\mathrm{K}_{2} \mathrm{O}$ & 0.25 & 0.26 & 0.22 & 0.26 & 0.25 & 0.21 & 0.25 & 0.26 & 0.22 & 0.25 & 0.25 & 0.2 \\
\hline $\mathrm{MgO}$ & 1.00 & 0.96 & 1.12 & 0.96 & 0.92 & 1.12 & 0.97 & 0.94 & 1.14 & 0.95 & 0.92 & 1.14 \\
\hline $\mathrm{Na}_{2} \mathrm{O}$ & 19.97 & 18.44 & 16.38 & 19.23 & 18.78 & 16.49 & 18.99 & 18.05 & 16.31 & 19.80 & 17.15 & 16.37 \\
\hline $\mathrm{NiO}$ & 0.01 & 0.01 & 0.05 & 0.01 & 0.01 & 0.05 & 0.01 & 0.01 & 0.05 & 0.01 & 0.01 & 0.06 \\
\hline $\mathrm{PbO}$ & 0.02 & 0.02 & $\mathrm{NA}^{*}$ & 0.02 & 0.02 & $\mathrm{NA}^{*}$ & 0.02 & 0.02 & $\mathrm{NA}^{*}$ & 0.01 & 0.02 & $\mathrm{NA}^{*}$ \\
\hline $\mathrm{SiO}_{2}$ & 36.71 & 37.67 & 35.88 & 37.45 & 37.55 & 36.19 & 37.10 & 37.73 & 35.13 & 36.87 & 37.71 & 37.93 \\
\hline $\mathrm{V}_{2} \mathrm{O}_{5}$ & 1.16 & 1.20 & $\mathrm{NA}^{*}$ & 1.18 & 1.20 & NA* & 1.19 & 1.22 & $\mathrm{NA}^{*}$ & 1.19 & 1.28 & NA* \\
\hline $\mathrm{ZnO}$ & 2.86 & 2.95 & 2.91 & 2.86 & 2.92 & 2.88 & 2.94 & 2.98 & 2.87 & 2.85 & 3.15 & 2.91 \\
\hline $\mathrm{ZrO}_{2}$ & 3.03 & 3.07 & 2.73 & 3.76 & 4.02 & 3.56 & 4.78 & 4.92 & 4.29 & 6.10 & 7.00 & 5.73 \\
\hline $\mathrm{Cl}$ & 0.48 & 0.48 & $\mathrm{NA}^{*}$ & 0.41 & 0.42 & $\mathrm{NA}^{*}$ & 0.49 & 0.48 & $\mathrm{NA}^{*}$ & 0.36 & 0.36 & $\mathrm{NA}^{*}$ \\
\hline $\mathrm{F}$ & NA* & NA* & $\mathrm{NA}^{*}$ & $\mathrm{NA}^{*}$ & NA* & $\mathrm{NA}^{*}$ & $\mathrm{NA}^{*}$ & $\mathrm{NA}^{*}$ & $\mathrm{NA}^{*}$ & $\mathrm{NA}^{*}$ & $\mathrm{NA}^{*}$ & NA* \\
\hline $\mathrm{P}_{2} \mathrm{O}_{5}$ & 0.32 & 0.35 & 0.31 & 0.34 & 0.35 & 0.32 & 0.33 & 0.36 & 0.34 & 0.34 & 0.37 & 0.39 \\
\hline $\mathrm{SO}_{3}$ & 1.12 & 1.00 & 1.15 & 1.06 & 0.90 & 1.01 & 1.09 & 1.02 & 0.87 & 1.02 & 0.97 & 0.93 \\
\hline SUM & 100.2 & 100.3 & 94.7 & 100.2 & 100.3 & 95.6 & 100.1 & 100.2 & 93.8 & 99.9 & 100.0 & 96.9 \\
\hline
\end{tabular}

${ }^{*}$ Not analyzed - target values used in sums. 
Table 2.4. Results of 7-day PCT (ASTM C1285-98 at $90^{\circ} \mathrm{C}$ ) and VHT (at $200^{\circ} \mathrm{C}$ for 24 Days (g/m $/ \mathrm{m}^{2} /$ day)) for Four New LAW Envelope C Glasses.

\begin{tabular}{|c|c|c|c|c|c|}
\hline Glass ID & LAWC100 & LAWC100R1* & LAWC101 & LAWC102 & LAWC103 \\
\hline \multicolumn{6}{|c|}{ 7-Day PCT, Stainless Steel Vessel; S/V=2000 $\mathrm{m}^{-1}$} \\
\hline \multicolumn{6}{|c|}{ Concentration (ppm) } \\
\hline B & 44.44 & 71.49 & 54.71 & 77.14 & 91.20 \\
\hline $\mathrm{Na}$ & 128.60 & 224.3 & 185.70 & 243.90 & 287.40 \\
\hline $\mathrm{Si}$ & 33.49 & 51.12 & 43.31 & 51.61 & 61.39 \\
\hline \multicolumn{6}{|l|}{ Normalized Concentrations $(\mathrm{g} / \mathrm{L})$} \\
\hline $\mathrm{B}$ & 1.05 & 1.68 & 1.36 & 1.82 & 2.15 \\
\hline $\mathrm{Na}$ & 0.87 & 1.51 & 1.25 & 1.64 & 1.94 \\
\hline $\mathrm{Si}$ & 0.20 & 0.30 & 0.25 & 0.30 & 0.36 \\
\hline $\mathrm{pH}$ & 10.61 & 11.06 & 11.08 & 11.15 & 11.25 \\
\hline \multicolumn{6}{|l|}{ Normalized Mass Loss $\left(\mathrm{g} / \mathrm{m}^{2}\right)$} \\
\hline $\mathrm{B}$ & 0.52 & 0.84 & 0.68 & 0.91 & 1.07 \\
\hline $\mathrm{Na}$ & 0.43 & 0.76 & 0.63 & 0.82 & 0.97 \\
\hline $\mathrm{Si}$ & 0.10 & 0.15 & 0.13 & 0.15 & 0.18 \\
\hline \multicolumn{6}{|l|}{ Normalized Loss Rate (g/m²/day) } \\
\hline $\mathrm{B}$ & 0.08 & 0.12 & 0.10 & 0.13 & 0.15 \\
\hline $\mathrm{Na}$ & 0.06 & 0.11 & 0.09 & 0.12 & 0.14 \\
\hline $\mathrm{Si}$ & 0.01 & 0.02 & 0.02 & 0.02 & 0.03 \\
\hline \multicolumn{6}{|l|}{ VHT Alteration ( 24 days at $200^{\circ} \mathrm{C}$ ) } \\
\hline Alteration depth $(\mu \mathrm{m})$ & 95 & 144 & 67 & 141 & 5 \\
\hline $\begin{array}{l}\text { Alteration Rate (g/m²/day) calculated } \\
\text { using measured density }\end{array}$ & 10.3 & 15.6 & 7.4 & 15.7 & 0.6 \\
\hline
\end{tabular}

* LAWC100R1 is a remelt of LAWC100 
Table 2.5. Viscosities and Electrical Conductivities of Four New LAW Envelope C Crucible Glasses.

\begin{tabular}{|c|c|c|c|c|c|c|}
\hline Glass ID & LAWC100 & LAWC100R1 ${ }^{*}$ & $\begin{array}{c}\text { WVY-G-95A Melter } \\
\text { Glass }\end{array}$ & LAWC101 & LAWC102 & LAWC103 \\
\hline \multicolumn{7}{|c|}{ Viscosity (poise) } \\
\hline $900^{\circ} \mathrm{C}$ & 821 & 528 & 537 & 670 & 499 & 578 \\
\hline $950^{\circ} \mathrm{C}$ & 347 & 236 & 233 & 279 & 216 & 239 \\
\hline $1000^{\circ} \mathrm{C}$ & 167 & 119 & 116 & 136 & 107 & 114 \\
\hline $1050^{\circ} \mathrm{C}$ & 90 & 66 & 65 & 75 & 58 & 61 \\
\hline $1100^{\circ} \mathrm{C}$ & 52 & 39 & 39 & 45 & 34 & 35 \\
\hline $1150^{\circ} \mathrm{C}$ & 32 & 25 & 25 & 29 & 22 & 22 \\
\hline $1200^{\circ} \mathrm{C}$ & 21 & 17 & 17 & 20 & 15 & 15 \\
\hline $1250^{\circ} \mathrm{C}$ & 15 & 12 & 12 & 14 & 10 & 10 \\
\hline \multicolumn{7}{|c|}{ Electrical Conductivity (S/cm) } \\
\hline $950^{\circ} \mathrm{C}$ & 0.11 & 0.13 & 0.12 & 0.19 & 0.20 & 0.20 \\
\hline $1000^{\circ} \mathrm{C}$ & 0.15 & 0.17 & 0.17 & 0.24 & 0.26 & 0.26 \\
\hline $1050^{\circ} \mathrm{C}$ & 0.19 & 0.22 & 0.22 & 0.30 & 0.31 & 0.31 \\
\hline $1100^{\circ} \mathrm{C}$ & 0.24 & 0.27 & 0.29 & 0.36 & 0.38 & 0.37 \\
\hline $1150^{\circ} \mathrm{C}$ & 0.29 & 0.33 & 0.35 & 0.42 & 0.46 & 0.43 \\
\hline $1200^{\circ} \mathrm{C}$ & 0.35 & 0.39 & 0.42 & 0.49 & 0.54 & 0.48 \\
\hline $1250^{\circ} \mathrm{C}$ & 0.41 & 0.47 & 0.49 & 0.55 & 0.63 & 0.53 \\
\hline
\end{tabular}

* LAWC100R1 is a remelt of LAWC100 
Table 2.6. Measured Densities and Glass Transition Temperatures (by Differential Thermal Analysis) of Four New LAW Envelope C Crucible Glasses.

\begin{tabular}{|c|c|c|c|c|}
\hline Glass Name & LAWC100 & LAWC101 & LAWC102 & LAWC103 \\
\hline Density $20^{\circ} \mathrm{C}(\mathrm{g} / \mathrm{cC})$ & 2.600 & 2.640 & 2.665 & 2.697 \\
\hline $\mathrm{T}_{\mathrm{G}}\left({ }^{\circ} \mathrm{C}\right)$ & 511 & 499 & 506 & 507 \\
\hline
\end{tabular}

Table 2.7. Results of K-3 Corrosion Testing for Four New LAW Envelope C Crucible Glasses.

\begin{tabular}{|l|c|c|c|}
\hline Glass ID & LAWC100 & LAWC101 & LAWC102 \\
\hline Coupon ID & C100K3 & C101K3 & C102K3 \\
\hline Depth of altered zone (inches) & $0.0300 ”$ & $0.0230 ”$ & $0.0270 ”$ \\
\hline Neck loss (inches) & $0.0360 ”$ & $0.0270 ”$ & $0.0310 ”$ \\
\hline Half-down loss (inches) & $0.0040 ”$ & $0.0030 ”$ & $0.0440 ”$ \\
\hline
\end{tabular}




\section{Table 2.8. Summary of Test Results for Selected Glass Formulation LAWC100 and Comparison to ILAW Requirements.}

\begin{tabular}{|l|c|c|c|}
\hline Test & Requirement & $\begin{array}{c}\text { Test Result for } \\
\text { LAWC100 }\end{array}$ & $\begin{array}{c}\text { Test Result for } \\
\text { LAWC100R1** }\end{array}$ \\
\hline Density of glass & $<3.7 \mathrm{~g} / \mathrm{cc}$ & $2.600 \mathrm{~g} / \mathrm{cc}$ & - \\
\hline Crystalline Phase & Phase Identification & $\begin{array}{c}\text { Clear homogeneous glass } \\
\text { down to } 850^{\circ} \mathrm{C} .\end{array}$ & - \\
\hline Liquidus & $<950^{\circ} \mathrm{C}$ & $<850^{\circ} \mathrm{C}$ & - \\
\hline Centerline Canister Cooling & Phase Identification & Clear homogeneous glass & $0.84 \mathrm{~g} / \mathrm{m}^{2}$ \\
\hline PCT B (g/m $\left.{ }^{2}\right)$ & $<2.0 \mathrm{~g} / \mathrm{m}^{2}$ & $0.52 \mathrm{~g} / \mathrm{m}^{2}$ & $0.76 \mathrm{~g} / \mathrm{m}^{2}$ \\
\hline PCT Na $\left(\mathrm{g} / \mathrm{m}^{2}\right)$ & $<2.0 \mathrm{~g} / \mathrm{m}^{2}$ & $0.43 \mathrm{~g} / \mathrm{m}^{2}$ & $0.15 \mathrm{~g} / \mathrm{m}^{2}$ \\
\hline PCT Si $\left(\mathrm{g} / \mathrm{m}^{2}\right)$ & $<2.0 \mathrm{~g} / \mathrm{m}^{2}$ & $0.10 \mathrm{~g} / \mathrm{m}^{2}$ & $15.6 \mathrm{~g} / \mathrm{m}^{2} / \mathrm{day}$ \\
\hline VHT at $200^{\circ} \mathrm{C}\left(\mathrm{g} / \mathrm{m}^{2} / \mathrm{day}\right)$ & $<50 \mathrm{~g} / \mathrm{m}^{2} / \mathrm{day}$ & $10.3 \mathrm{~g} / \mathrm{m}^{2} / \mathrm{day}$ & $39 \mathrm{P}$ \\
\hline Viscosity $(\mathrm{poise})$ at $1100^{\circ} \mathrm{C}$ & 10 to $150 \mathrm{P}$ & $52 \mathrm{P}$ & $0.27 \mathrm{~S} / \mathrm{cm}^{2}$ \\
\hline $\begin{array}{l}\text { Conductivity }\left(\mathrm{S} / \mathrm{cm}^{2}\right) \text { at } \\
1100^{\circ} \mathrm{C}\end{array}$ & 0.2 to $0.7 \mathrm{~S} / \mathrm{cm}$ & $0.24 \mathrm{~S} / \mathrm{cm}$ & - \\
\hline $\mathrm{T}_{\mathrm{G}}\left({ }^{\circ} \mathrm{C}\right)$ & Report for modeling & $511^{\circ} \mathrm{C}$ & \\
\hline
\end{tabular}

* "Design, Construction, and Commissioning of the Hanford Tank Waste Treatment and Immobilization Plant", Contract Number: DE-AC27-01RV14136, Modification A029, U. S. Department of Energy, Office of River Protection, Richland WA, 2001, as amended.

- Empty data field

** LAWC100R1 is a remelt of LAWC100 
The Catholic University of America Vitreous State Laboratory
LAW Envelope C Glass Formulation Testing

to Increase Waste Loading

Final Report, VSL-05R5900-1, Rev. 0

Table 2.9. Oxide Composition of LAW Envelope C Simulant and Corresponding Glass Composition Used in Melter Tests (wt\%).

\begin{tabular}{|c|c|c|c|}
\hline Component & $\begin{array}{l}\text { AN-102 waste } \\
\text { contribution }\end{array}$ & $\begin{array}{l}\text { Glass former } \\
\text { additives }\end{array}$ & $\begin{array}{c}\text { LAWC100 } \\
\text { (for AN-102) }\end{array}$ \\
\hline Loading & $24.06 \%$ & $75.94 \%$ & - \\
\hline $\mathrm{Al}_{2} \mathrm{O}_{3}$ & 1.47 & 8.69 & 10.16 \\
\hline $\mathrm{B}_{2} \mathrm{O}_{3}$ & 0.01 & 13.68 & 13.68 \\
\hline $\mathrm{CaO}$ & 0.04 & 7.97 & 8.02 \\
\hline $\mathrm{Cr}_{2} \mathrm{O}_{3}$ & 0.02 & - & 0.02 \\
\hline $\mathrm{Fe}_{2} \mathrm{O}_{3}$ & - & 1.00 & 1.00 \\
\hline $\mathrm{K}_{2} \mathrm{O}$ & 0.15 & - & 0.15 \\
\hline $\mathrm{MgO}$ & - & 1.00 & 1.00 \\
\hline $\mathrm{Na}_{2} \mathrm{O}^{(\mathrm{a})}$ & $19.42+0.35^{(1)}+0.23^{(2)}$ & - & 20.00 \\
\hline $\mathrm{NiO}$ & 0.034 & - & 0.03 \\
\hline $\mathrm{PbO}$ & 0.013 & - & 0.01 \\
\hline $\mathrm{SiO}_{2}$ & 0.012 & 36.603 & 36.62 \\
\hline $\mathrm{V}_{2} \mathrm{O}_{5}$ & - & 1.00 & 1.00 \\
\hline $\mathrm{ZnO}$ & - & 3.00 & 3.00 \\
\hline $\mathrm{ZrO}_{2}$ & - & 3.00 & 3.00 \\
\hline $\mathrm{Cl}$ & 0.65 & - & 0.65 \\
\hline $\mathrm{F}$ & 0.19 & - & 0.19 \\
\hline $\mathrm{P}_{2} \mathrm{O}_{5}$ & 0.27 & - & 0.27 \\
\hline $\mathrm{SO}_{3}^{(b)}$ & $0.75+0.45^{(1)}$ & - & 1.20 \\
\hline SUM & 24.05 & 75.95 & 100.00 \\
\hline
\end{tabular}

(a) Simulant was ordered at a concentration of $19.42 \mathrm{wt} \% \mathrm{Na}_{2} \mathrm{O}$ and modified before each melter test with (1) $\mathrm{Na} 2 \mathrm{SO} 4$ and (2) $\mathrm{NaOH}$ additions to obtain $20 \mathrm{wt} \% \mathrm{Na} 2 \mathrm{O}$ in the glass. (b) Concentration of SO3 was increased in steps during the melter tests from $0.75 \mathrm{wt} \% \mathrm{SO} 3$ in the glass up to $1.5 \mathrm{wt} \%$.

- Empty data field 
The Catholic University of America Vitreous State Laboratory
LAW Envelope C Glass Formulation Testing

to Increase Waste Loading

Final Report, VSL-05R5900-1, Rev. 0

Table 2.10. Glass Former Additives for 1 Liter of LAW Envelope C Simulant (8 M Na) and Corresponding Melter Feed Properties.

\begin{tabular}{|c|c|}
\hline Additives Source & Feed LAWC100 \\
\hline Additives in Glass (wt\%) & 75.94 \\
\hline Kyanite $\left(\mathrm{Al}_{2} \mathrm{SiO}_{5}\right) 325$ Mesh (Kyanite Mining) (g) & 196.01 \\
\hline $\mathrm{H}_{3} \mathrm{BO}_{3}$ (US Borax - Technical Granular) (g) & 304.20 \\
\hline Wollanstonite NYAD 325 Mesh (NYCO Minerals) (g) & 208.16 \\
\hline $\mathrm{Fe}_{2} \mathrm{O}_{3}$ (Prince Manufacturing) (g) & 9.46 \\
\hline Olivine $\left(\mathrm{Mg}_{2} \mathrm{SiO}_{4}\right) 325$ Mesh (\#180 Unimin) (g) & 22.49 \\
\hline $\mathrm{SiO}_{2}$ (Sil-co-Sil 75 US Silica) (g) & 232.15 \\
\hline $\mathrm{V}_{2} \mathrm{O}_{5}$ (Pulva ground STRATCOR) g & 12.40 \\
\hline ZnO (KADOX - 920 Zinc Corp. of America) (g) & 37.28 \\
\hline Zircon $\mathrm{ZrSiO}_{4}$ (Flour) Mesh 325 (AM. Mineral) (g) & 55.82 \\
\hline Supplemental $\mathrm{Na}_{2} \mathrm{SO}_{4}$ & Variable \\
\hline Addition of Sucrose as Reductant (g) & 37.85 \\
\hline KI (spike) (g) & 1.60 \\
\hline Simulant Weight for 1 liter (g) & 1379 \\
\hline Sum of Additives (g) & 1116 \\
\hline Sum of Complete Batch (g) & 2501 \\
\hline Target Final Volume (l) & 1.44 \\
\hline Target Density (g/ml) & 1.70 \\
\hline Target Glass Produced (g) & 1240 \\
\hline Target Weight \% Water in Slurry Feed & $37 \%$ \\
\hline Target Weight \% Additives in Slurry & $45 \%$ \\
\hline Target Glass Yield (g/kg of Feed) & 496 \\
\hline Target Glass Yield (g/l of Feed) & 862 \\
\hline Target Total Solids (g/l of Feed) & 1091 \\
\hline Target Additives (g/l of Feed) & 776 \\
\hline
\end{tabular}

Table 2.11. $\mathrm{NaOH}$ and $\mathrm{Na}_{2} \mathrm{SO}_{4}$ Additions Required to Obtain 20 wt\% $\mathrm{Na}_{2} \mathrm{O}$ and Various $\mathrm{SO}_{3}$ Concentrations in the Glass Ranging from 0.75 to $1.5 \mathrm{wt} \%$.

\begin{tabular}{|c|c|c|}
\hline $\begin{array}{c}\text { Final } \\
\mathrm{SO}_{3} \text { wt\% }\end{array}$ & $\begin{array}{c}\text { NaOH needed } \\
\text { per kg of feed } \\
\text { (grams) }\end{array}$ & $\begin{array}{c}\mathrm{Na}_{2} \mathrm{SO}_{4} \text { needed } \\
\text { per kg of feed } \\
\text { (grams) }\end{array}$ \\
\hline 0.75 & 1.83 & 0.00 \\
\hline 1.00 & 1.21 & 2.28 \\
\hline 1.25 & 0.61 & 4.56 \\
\hline 1.50 & 0.00 & 6.83 \\
\hline
\end{tabular}


Table 2.12. Properties of Feed Samples from Crucible Tests and DM10 and DM100 Melter Tests.

\begin{tabular}{|c|c|c|c|c|c|c|c|c|c|c|c|c|}
\hline \multirow{2}{*}{$\begin{array}{l}\text { Melter } \\
\text { Type }\end{array}$} & \multirow{2}{*}{ Test } & \multirow{2}{*}{ Date } & \multirow{2}{*}{ Name } & \multirow{2}{*}{$\begin{array}{c}\% \\
\text { Water }\end{array}$} & \multirow{2}{*}{$\frac{\text { Density }}{(\mathrm{g} / \mathrm{ml})}$} & \multicolumn{2}{|c|}{ Glass Yield } & \multirow{2}{*}{$\mathbf{p H}$} & \multirow{2}{*}{$\begin{array}{c}\text { Yield } \\
\text { Stress (Pa) }\end{array}$} & \multicolumn{3}{|c|}{ Viscosity } \\
\hline & & & & & & (kg/kg) & $(g / l)$ & & & @ 10/s & @ 100/s & @ 1000/s \\
\hline \multicolumn{4}{|c|}{ Target for Feed LAWC100 } & 37 & 1.70 & 0.496 & 862 & NA & NA & NA & NA & NA \\
\hline \multicolumn{4}{|c|}{$\begin{array}{l}\text { Feed for crucible testing F8LC100H at } 0.75 \mathrm{wt} \% \\
\qquad \mathrm{SO}_{3}\end{array}$} & 37.4 & 1.70 & 0.484 & 823 & 6.77 & 0.1 & 2.43 & 1.11 & 0.80 \\
\hline \multicolumn{4}{|c|}{$\begin{array}{l}\text { Feed for crucible testing F8LC100S at } 1.50 \mathrm{wt} \% \\
\qquad \mathrm{SO}_{3}\end{array}$} & 37.3 & 1.69 & 0.481 & 813 & 6.77 & 0.1 & 2.18 & 1.00 & 0.76 \\
\hline \multirow{4}{*}{ DM100 } & 1 & $6 / 2 / 05$ & WVY-F-33A & 42.3 & 1.65 & 0.434 & 717 & 6.84 & NA & NA & NA & NA \\
\hline & \multirow{3}{*}{2} & $6 / 7 / 05$ & WVY-F-115A & 39.0 & 1.66 & 0.480 & 798 & 7.04 & NA & NA & NA & NA \\
\hline & & $6 / 8 / 05$ & WVY-F-130A & 39.7 & 1.66 & 0.467 & 776 & 7.05 & 0.9 & 0.93 & 0.47 & 0.44 \\
\hline & & $6 / 10 / 05$ & WVZ-F-16A & 42.1 & 1.66 & 0.461 & 765 & 7.21 & NA & NA & NA & NA \\
\hline \multicolumn{2}{|c|}{ DM10 } & $5 / 25 / 05$ & K10-F-58A & NA & NA & NA & NA & NA & 0.4 & 0.72 & 0.49 & 0.40 \\
\hline \multicolumn{4}{|c|}{ Average Melter Feed } & 40.8 & 1.66 & 0.461 & 764 & 7.03 & 0.7 & 0.82 & 0.48 & 0.42 \\
\hline \multicolumn{4}{|c|}{ Average( LAWA161) [2] } & 38.7 & 1.68 & 0.472 & 791 & 11.50 & 0.3 & 0.42 & 0.35 & 0.38 \\
\hline
\end{tabular}

NA - Not Analyzed or Not Applicable 
Table 2.13. XRF Analyzed Compositions for Melter Feed Samples (wt\%).

\begin{tabular}{|c|c|c|c|c|c|c|c|c|c|}
\hline Target $\mathrm{SO}_{3}$ & \multicolumn{2}{|c|}{1.625} & \multicolumn{2}{|c|}{1.3} & \multicolumn{2}{|c|}{1.23} & \multicolumn{2}{|c|}{1.15} & \multirow[b]{2}{*}{$\begin{array}{c}\text { Avg. \% } \\
\text { Dev. }\end{array}$} \\
\hline Constituent & Target & $\begin{array}{c}\text { K10-F- } \\
58 \mathrm{~A}\end{array}$ & Target & $\begin{array}{c}\text { WVY-F- } \\
115 A\end{array}$ & Target & $\begin{array}{c}\text { WVY-F- } \\
130 \mathrm{~A}\end{array}$ & Target & $\begin{array}{c}\text { WVZ-F- } \\
16 A\end{array}$ & \\
\hline $\mathrm{Al}_{2} \mathrm{O}_{3}$ & 10.10 & 9.56 & 10.14 & 10.15 & 10.14 & 10.13 & 10.15 & 9.98 & -1.74 \\
\hline $\mathrm{B}_{2} \mathrm{O}_{3}$ * & 13.61 & 13.61 & 13.66 & 13.66 & 13.67 & 13.67 & 13.68 & 13.68 & NC \\
\hline $\mathrm{CaO}$ & 7.98 & 7.57 & 8.00 & 7.39 & 8.01 & 7.53 & 8.01 & 7.89 & -5.03 \\
\hline $\mathrm{Cl}$ & 0.64 & 0.38 & 0.65 & 0.03 & 0.65 & 0.02 & 0.65 & 0.04 & $\mathrm{NC}$ \\
\hline $\mathrm{Cr}_{2} \mathrm{O}_{3}$ & 0.02 & 0.05 & 0.02 & 0.04 & 0.02 & 0.04 & 0.02 & 0.05 & $\mathrm{NC}$ \\
\hline $\mathrm{F}$ & 0.19 & NA & 0.19 & NA & 0.19 & NA & 0.19 & NA & $\mathrm{NC}$ \\
\hline $\mathrm{Fe}_{2} \mathrm{O}_{3}$ & 1.00 & 1.03 & 1.00 & 1.05 & 1.00 & 1.09 & 1.00 & 1.04 & 5.18 \\
\hline $\mathrm{I}$ & 0.10 & 0.01 & 0.10 & $<0.01$ & 0.10 & $<0.01$ & 0.10 & $<0.01$ & $\mathrm{NC}$ \\
\hline $\mathrm{K}_{2} \mathrm{O}$ & 0.15 & 0.32 & 0.15 & 0.31 & 0.15 & 0.31 & 0.15 & 0.32 & $\mathrm{NC}$ \\
\hline $\mathrm{MgO}$ & 1.00 & 0.59 & 1.00 & 0.86 & 1.00 & 0.80 & 1.00 & 0.60 & -28.79 \\
\hline $\mathrm{MnO}$ & $\S$ & 0.01 & $\S$ & 0.01 & $\S$ & 0.01 & $\S$ & 0.02 & $\mathrm{NC}$ \\
\hline $\mathrm{Na}_{2} \mathrm{O}$ & 19.90 & 21.16 & 19.96 & 19.50 & 19.97 & 19.26 & 19.99 & 19.77 & -0.15 \\
\hline $\mathrm{NiO}$ & 0.03 & 0.02 & 0.03 & 0.02 & 0.03 & 0.02 & 0.03 & 0.02 & $\mathrm{NC}$ \\
\hline $\mathrm{P}_{2} \mathrm{O}_{5}$ & 0.26 & 0.38 & 0.26 & 0.38 & 0.26 & 0.40 & 0.27 & 0.39 & $\mathrm{NC}$ \\
\hline $\mathrm{PbO}$ & 0.01 & 0.01 & 0.01 & $<0.01$ & 0.01 & 0.01 & 0.01 & 0.01 & $\mathrm{NC}$ \\
\hline $\mathrm{SiO}_{2}$ & 36.42 & 36.28 & 36.54 & 38.49 & 36.57 & 38.46 & 36.60 & 37.87 & 3.40 \\
\hline $\mathrm{SO}_{3}$ & 1.62 & 1.37 & 1.30 & 1.02 & 1.23 & 0.92 & 1.15 & 1.00 & $\mathrm{NC}$ \\
\hline $\mathrm{TiO}_{2}$ & $\S$ & 0.20 & $\S$ & 0.20 & $\S$ & 0.21 & $\S$ & 0.21 & $\mathrm{NC}$ \\
\hline $\mathrm{V}_{2} \mathrm{O}_{5}$ & 1.00 & 1.26 & 1.00 & 1.14 & 1.00 & 1.18 & 1.00 & 1.28 & 21.65 \\
\hline $\mathrm{ZnO}$ & 2.98 & 3.13 & 2.99 & 2.77 & 3.00 & 2.87 & 3.00 & 3.16 & -0.37 \\
\hline $\mathrm{ZrO}_{2}$ & 2.98 & 3.04 & 2.99 & 2.96 & 3.00 & 3.07 & 3.00 & 2.68 & -1.76 \\
\hline Sum & 100.00 & 100.00 & 100.00 & 100.00 & 100.00 & 100.00 & 100.00 & 100.00 & $\mathrm{NC}$ \\
\hline
\end{tabular}

* Target value; § - Not a target constituent; NA - Not analyzed; NC - Not calculated 
Table 3.1. Summary of DM10 Test Conditions and Results.

\begin{tabular}{|c|c|c|c|c|c|c|c|}
\hline \multicolumn{2}{|r|}{ Test } & C1A & $\mathrm{C} 1 \mathrm{~B}$ & $\mathrm{C} 1 \mathrm{C}$ & $\mathrm{C} 2 \mathrm{~A}$ & $\mathrm{C} 2 \mathrm{~B}$ & $\mathrm{C} 2 \mathrm{C}$ \\
\hline \multirow{3}{*}{ Time } & Feed Start & $\begin{array}{c}\text { 5/19/05 } \\
13: 45\end{array}$ & $\begin{array}{c}5 / 20 / 05 \\
4: 48\end{array}$ & $\begin{array}{c}\text { 5/20/05 } \\
16: 45\end{array}$ & $\begin{array}{c}5 / 21 / 05 \\
8: 30\end{array}$ & $\begin{array}{c}5 / 21 / 05 \\
22: 43\end{array}$ & $\begin{array}{c}5 / 22 / 05 \\
14: 30\end{array}$ \\
\hline & Feed End & $\begin{array}{c}5 / 20 / 05 \\
4: 00\end{array}$ & $\begin{array}{c}5 / 20 / 05 \\
12: 42\end{array}$ & $\begin{array}{c}5 / 21 / 05 \\
7: 00\end{array}$ & $\begin{array}{c}\text { 5/21/05 } \\
22: 00\end{array}$ & $\begin{array}{c}5 / 22 / 05 \\
13: 43\end{array}$ & $\begin{array}{c}5 / 23 / 05 \\
5: 30\end{array}$ \\
\hline & Net Slurry Feeding (hr) & 14.3 & 7.9 & 14.3 & 13.5 & 15.0 & 15.0 \\
\hline \multirow{2}{*}{$\begin{array}{c}\text { Glass } \\
\text { Temperature } \\
\left(\mathrm{C}^{\circ}\right)\end{array}$} & Target & 1150 & 1150 & 1150 & 1175 & 1175 & 1175 \\
\hline & Average Measured & 1152 & 1151 & 1150 & 1170 & 1178 & 1166 \\
\hline \multicolumn{2}{|c|}{$\begin{array}{l}\text { Average Measured Electrode Temperature } \\
\qquad\left(\mathrm{C}^{\circ}\right)\end{array}$} & 1021 & 1018 & 1032 & 1060 & 1065 & 1063 \\
\hline \multirow{2}{*}{ Feed } & $\mathrm{wt} \% \mathrm{SO}_{3}$ as glass & 1.0 & 1.25 & 1.125 & 1.125 & 1.25 & 1.375 \\
\hline & Feed Used (kg) & 53.38 & 29.34 & 55.26 & 52.30 & 58.66 & 58.68 \\
\hline \multicolumn{2}{|c|}{ Average Production Rate (kg/m²/day) } & 2141 & 2122 & 2203 & 2214 & 2235 & 2235 \\
\hline \multicolumn{2}{|c|}{ Average Bubbling Rate (lpm) } & 4.0 & 3.4 & 2.9 & 3.0 & 2.4 & 2.0 \\
\hline \multirow{4}{*}{ Product } & $\begin{array}{l}\text { Secondary Phases on Melt } \\
\text { Surface at Test End }\end{array}$ & No & Yes & No & No & No & Trace \\
\hline & $\begin{array}{c}\text { Secondary Phases in Poured } \\
\text { Glass at Test End }\end{array}$ & No & Yes & No & No & No & No \\
\hline & Measured wt\% $\mathrm{SO}_{3}$ & 0.92 & 1.10 & 1.07 & 1.03 & 1.17 & 1.24 \\
\hline & $\begin{array}{l}\text { \% Feed Sulfur in Glass } \\
\text { Product }\end{array}$ & 92 & 88 & 95 & 92 & 94 & 90 \\
\hline
\end{tabular}

- Empty data field 
Table 3.1. Summary of DM10 Test Conditions and Results (continued).

\begin{tabular}{|c|c|c|c|c|}
\hline \multicolumn{2}{|r|}{ Test } & C3A & C3B & C3C \\
\hline \multirow{3}{*}{ Time } & Feed Start & $\begin{array}{c}5 / 23 / 05 \\
6: 13\end{array}$ & $\begin{array}{c}5 / 23 / 05 \\
22: 10\end{array}$ & $\begin{array}{c}5 / 24 / 05 \\
15: 10\end{array}$ \\
\hline & Feed End & $\begin{array}{c}5 / 23 / 05 \\
21: 10\end{array}$ & $\begin{array}{c}5 / 24 / 05 \\
13: 03\end{array}$ & $\begin{array}{c}5 / 25 / 05 \\
6: 10\end{array}$ \\
\hline & Net Slurry Feeding (hr) & 15.0 & 14.9 & 15.0 \\
\hline \multirow{2}{*}{$\begin{array}{c}\text { Glass } \\
\text { Temperature } \\
\left(\mathrm{C}^{\circ}\right)\end{array}$} & Target & 1200 & 1200 & 1200 \\
\hline & Average Measured & 1188 & 1186 & 1170 \\
\hline \multicolumn{2}{|c|}{$\begin{array}{l}\text { Average Measured Electrode Temperature } \\
\qquad\left(\mathrm{C}^{\circ}\right)\end{array}$} & 1081 & 1081 & 1104 \\
\hline \multirow{2}{*}{ Feed } & wt $\% \mathrm{SO}_{3}$ as glass & 1.375 & 1.625 & 1.625 \\
\hline & Feed Used (kg) & 57.80 & 57.62 & 70.06 \\
\hline \multicolumn{2}{|c|}{ Average Production Rate (kg/m²/day) } & 2209 & 2213 & 2669 \\
\hline \multicolumn{2}{|c|}{ Average Bubbling Rate (lpm) } & 0.7 & 0.2 & 0.4 \\
\hline \multirow{4}{*}{ Product } & $\begin{array}{l}\text { Secondary Phases on Melt } \\
\text { Surface at Test End }\end{array}$ & No & Yes & Yes \\
\hline & $\begin{array}{c}\text { Secondary Phases in Poured } \\
\text { Glass at Test End }\end{array}$ & No & No & No \\
\hline & Measured wt $\% \mathrm{SO}_{3}$ & 1.20 & 1.17 & 1.10 \\
\hline & $\begin{array}{l}\text { \% Feed Sulfur in Glass } \\
\text { Product }\end{array}$ & 87 & 72 & 68 \\
\hline
\end{tabular}

- Empty data field 
Table 3.2. Listing of DM10 Glasses Discharged, Masses, and Measured Sulfur Contents.

\begin{tabular}{|c|c|c|c|c|c|c|c|c|}
\hline \multirow{2}{*}{ Test } & \multirow{2}{*}{$\begin{array}{c}\mathbf{T} \\
\left({ }^{\circ} \mathrm{C}\right)\end{array}$} & \multirow{2}{*}{ Date } & \multirow{2}{*}{ Name } & \multirow{2}{*}{$\begin{array}{c}\text { Mass } \\
(\mathbf{k g})\end{array}$} & \multirow{2}{*}{$\begin{array}{c}\text { Cumulative } \\
\text { Mass (kg) }\end{array}$} & \multicolumn{2}{|c|}{$\mathrm{SO}_{3}(\mathrm{wt} \%)$} & \multirow{2}{*}{$\begin{array}{c}\text { Secondary Sulfate } \\
\text { Phase }\end{array}$} \\
\hline & & & & & & Target & Measured & \\
\hline \multirow{12}{*}{ C1A } & \multirow{28}{*}{1150} & \multirow{8}{*}{$5 / 19 / 05$} & J10-G-124A & - & - & \multirow{13}{*}{1.0} & - & - \\
\hline & & & J10-G-124B & - & - & & - & - \\
\hline & & & J10-G-130A & 5.40 & 5.40 & & 0.59 & No \\
\hline & & & J10-G-130B & - & - & & - & - \\
\hline & & & J10-G-130C & - & - & & - & - \\
\hline & & & J10-G-130D & 5.40 & 10.80 & & 0.78 & No \\
\hline & & & J10-G-131A & - & - & & - & - \\
\hline & & & J10-G-131B & 4.70 & 15.50 & & 0.85 & No \\
\hline & & \multirow{14}{*}{$5 / 20 / 05$} & J10-G-131C & - & - & & - & - \\
\hline & & & J10-G-134A & 4.64 & 20.14 & & 0.86 & No \\
\hline & & & J10-G-134B & - & - & & - & - \\
\hline & & & J10-G-134C & 4.62 & 24.76 & & 0.92 & No \\
\hline \multirow{6}{*}{ C1B } & & & J10-G-136A & - & - & & - & - \\
\hline & & & J10-G-136B & 5.64 & 30.40 & \multirow{5}{*}{1.25} & 1.07 & No \\
\hline & & & J10-G-137A & - & - & & - & - \\
\hline & & & J10-G-137B & 3.28 & 33.68 & & 1.18 & Yes \\
\hline & & & J10-G-137C & 2.66 & 36.34 & & 1.17 & Yes \\
\hline & & & J10-G-138A & 2.22 & 38.56 & & 1.10 & Yes \\
\hline \multirow{10}{*}{ C1C } & & & J10-G-142A & - & - & \multirow{20}{*}{1.125} & - & - \\
\hline & & & J10-G-142B & 7.14 & 45.70 & & 1.22 & No \\
\hline & & & J10-G-144A & - & - & & - & - \\
\hline & & & J10-G-144B & 5.74 & 51.44 & & 1.02 & No \\
\hline & & \multirow{16}{*}{$5 / 21 / 05$} & J10-G-144C & - & - & & - & - \\
\hline & & & J10-G-145A & 4.60 & 56.04 & & 1.11 & No \\
\hline & & & J10-G-145B & - & - & & - & - \\
\hline & & & J10-G-145C & 3.34 & 59.38 & & 1.08 & No \\
\hline & & & J10-G-145D & - & - & & - & - \\
\hline & & & J10-G-150A & 5.14 & 64.52 & & 1.07 & No \\
\hline \multirow{10}{*}{ C2A } & \multirow{18}{*}{1175} & & J10-G-151A & - & - & & - & - \\
\hline & & & J10-G-151B & 5.22 & 69.74 & & 1.02 & No \\
\hline & & & J10-G-152A & - & - & & - & - \\
\hline & & & J10-G-152B & 5.46 & 75.20 & & 0.99 & No \\
\hline & & & J10-G-152C & - & - & & - & - \\
\hline & & & J10-G-153A & 6.22 & 81.42 & & 1.05 & No \\
\hline & & & J10-G-153B & - & - & & - & - \\
\hline & & & J10-G-153C & - & - & & - & - \\
\hline & & & J10-G-153D & 6.40 & 87.82 & & 1.03 & No \\
\hline & & & J10-G-153E & 2.58 & 90.40 & & 1.03 & No \\
\hline \multirow{8}{*}{ C2B } & & & K10-G-5A & - & - & & - & - \\
\hline & & & K10-G-5B & 5.60 & 96.00 & & 1.02 & No \\
\hline & & & K10-G-6A & - & - & & - & - \\
\hline & & $5 / 23 / 05$ & K10-G-6B & 6.08 & 102.08 & 125 & 1.03 & No \\
\hline & & $5 / 2 \angle / 05$ & K10-G-6C & - & - & 1.25 & - & - \\
\hline & & & K10-G-10A & 4.76 & 106.84 & & 1.09 & No \\
\hline & & & K10-G-10B & - & - & & - & - \\
\hline & & & K10-G-10C & 4.76 & 111.60 & & 1.10 & No \\
\hline
\end{tabular}

- Empty data field 
Table 3.2. Listing of DM10 Glasses Discharged, Masses, and Measured Sulfur Contents (continued).

\begin{tabular}{|c|c|c|c|c|c|c|c|c|}
\hline \multirow{2}{*}{ Test } & \multirow{2}{*}{$\begin{array}{c}\mathrm{T} \\
\left({ }^{\circ} \mathrm{C}\right)\end{array}$} & \multirow{2}{*}{ Date } & \multirow{2}{*}{ Name } & \multirow{2}{*}{$\begin{array}{c}\text { Mass } \\
(\mathrm{kg})\end{array}$} & \multirow{2}{*}{$\begin{array}{c}\text { Cumulative } \\
\text { Mass (kg) }\end{array}$} & \multicolumn{2}{|c|}{$\mathrm{SO}_{3}(\mathrm{wt} \%)$} & \multirow{2}{*}{$\begin{array}{c}\text { Secondary Sulfate } \\
\text { Phase }\end{array}$} \\
\hline & & & & & & Target & Measured & \\
\hline \multirow{3}{*}{ C2B } & \multirow{12}{*}{1175} & \multirow{9}{*}{$5 / 22 / 05$} & K10-G-10D & - & - & \multirow{3}{*}{1.25} & - & - \\
\hline & & & K10-G-10E & 4.28 & 115.88 & & 1.09 & No \\
\hline & & & K10-G-11A & 2.70 & 118.58 & & 1.17 & No \\
\hline \multirow{9}{*}{$\mathrm{C} 2 \mathrm{C}$} & & & K10-G-11B & - & - & \multirow{19}{*}{1.375} & - & - \\
\hline & & & K10-G-11C & 5.50 & 124.08 & & 1.24 & No \\
\hline & & & K10-G-15A & - & - & & - & - \\
\hline & & & K10-G-15B & 5.88 & 129.96 & & 1.24 & No \\
\hline & & & K10-G-15C & - & - & & - & - \\
\hline & & & K10-G-16A & 6.36 & 136.32 & & 1.23 & No \\
\hline & & \multirow{14}{*}{$5 / 23 / 05$} & K10-G-16B & - & - & & - & - \\
\hline & & & K10-G-20A & 5.50 & 141.82 & & 1.24 & No \\
\hline & & & K10-G-20B & 3.84 & 145.66 & & 1.29 & No \\
\hline \multirow{10}{*}{ C3A } & \multirow{33}{*}{1200} & & K10-G-22A & - & - & & - & - \\
\hline & & & K10-G-23A & 6.16 & 151.82 & & 1.29 & No \\
\hline & & & K10-G-23B & - & - & & - & - \\
\hline & & & K10-G-23C & 4.74 & 156.56 & & 1.26 & No \\
\hline & & & K10-G-24A & - & - & & - & - \\
\hline & & & K10-G-24B & 5.52 & 162.08 & & 1.16 & No \\
\hline & & & K10-G-28A & - & - & & - & - \\
\hline & & & K10-G-28B & 5.74 & 167.82 & & 1.15 & No \\
\hline & & & K10-G-28C & - & - & & - & - \\
\hline & & & K10-G-30A & 5.60 & 173.42 & & 1.20 & No \\
\hline \multirow{10}{*}{ C3B } & & & K10-G-33A & - & - & \multirow{23}{*}{1.625} & - & - \\
\hline & & \multirow{15}{*}{$5 / 24 / 05$} & K10-G-34A & 6.52 & 179.94 & & 1.21 & No \\
\hline & & & K10-G-35A & - & - & & - & - \\
\hline & & & K10-G-36A & 4.96 & 184.90 & & 1.16 & No \\
\hline & & & K10-G-37A & - & - & & - & - \\
\hline & & & K10-G-37B & 4.38 & 189.28 & & 1.21 & No \\
\hline & & & K10-G-37C & - & - & & - & - \\
\hline & & & K10-G-40A & 3.74 & 193.02 & & 1.14 & No \\
\hline & & & K10-G-40B & - & - & & - & - \\
\hline & & & K10-G-41A & 7.52 & 200.54 & & 1.17 & No \\
\hline \multirow{13}{*}{ C3C* } & & & K10-G-45A & - & - & & - & - \\
\hline & & & K10-G-47A & 5.46 & 206.00 & & 1.16 & No \\
\hline & & & K10-G-47B & - & - & & - & - \\
\hline & & & K10-G-47C & 5.52 & 211.52 & & 1.09 & No \\
\hline & & & K10-G-48A & - & - & & - & - \\
\hline & & & K10-G-49A & 4.88 & 216.40 & & 1.10 & No \\
\hline & & & K10-G-50A & - & - & & - & - \\
\hline & & & K10-G-50B & 3.88 & 220.28 & & 1.14 & No \\
\hline & & & K10-G-53A & - & - & & - & - \\
\hline & & $5 / 25 / 05$ & K10-G-53B & 4.82 & 225.10 & & 1.11 & No \\
\hline & & & K10-G-53C & - & - & & - & - \\
\hline & & & K10-G-54A & 5.16 & 230.26 & & 1.06 & No \\
\hline & & & K10-G-56A & 2.62 & 232.88 & & 1.10 & No \\
\hline
\end{tabular}

- Empty data field

* Slurry was fed at high feed rate 
Table 3.3. Dip samples and Presence of Sulfate Layer During DM10 Melter Tests.

\begin{tabular}{|c|c|c|c|c|c|c|c|}
\hline Test & $\mathbf{T}\left({ }^{\circ} \mathbf{C}\right)$ & Date & Time & $\begin{array}{l}\text { Cumulative } \\
\text { Mass (Kg) }\end{array}$ & $\begin{array}{c}\text { Target } \mathrm{SO}_{3} \\
\text { (wt \%) }\end{array}$ & Name & $\begin{array}{c}\text { Secondary } \\
\text { Sulfate Phase? }\end{array}$ \\
\hline C1A & \multirow{8}{*}{1150} & \multirow{6}{*}{$5 / 20 / 05$} & 04:23 & 24.76 & 1.0 & J10-D-136A & No \\
\hline \multirow{5}{*}{ C1B } & & & $12: 45$ & \multirow{5}{*}{38.56} & \multirow{5}{*}{1.25} & J10-D-138A & Yes \\
\hline & & & $13: 34$ & & & J10-D-138B & Yes \\
\hline & & & $14: 17$ & & & J10-D-141A & Yes \\
\hline & & & $15: 30$ & & & J10-D-141B & Yes \\
\hline & & & $16: 31$ & & & J10-D-141C & No \\
\hline \multirow[t]{2}{*}{ C1C } & & \multirow{3}{*}{$5 / 21 / 05$} & 07:05 & \multirow{2}{*}{64.52} & \multirow{3}{*}{1.125} & J10-D-150A & Trace \\
\hline & & & $07: 36$ & & & J10-D-150B & No \\
\hline C2A & \multirow{3}{*}{1175} & & $22: 05$ & 81.42 & & J10-D-153A & No \\
\hline C2B & & $5 / 22 / 05$ & $13: 55$ & 118.58 & 1.25 & K10-D-11A & No \\
\hline $\mathrm{C} 2 \mathrm{C}$ & & \multirow{2}{*}{$5 / 23 / 05$} & $05: 45$ & 145.66 & \multirow{2}{*}{1.375} & K10-D-21A & No \\
\hline C3A & \multirow{18}{*}{1200} & & $21: 15$ & 173.42 & & K10-D-30A & Trace \\
\hline \multirow{4}{*}{ С3В } & & \multirow{4}{*}{$5 / 24 / 05$} & $12: 50$ & \multirow{4}{*}{200.54} & \multirow{17}{*}{1.625} & K10-D-41A & Yes \\
\hline & & & $13: 10$ & & & K10-D-41B & Yes \\
\hline & & & $13: 28$ & & & K10-D-41C & Yes \\
\hline & & & $13: 48$ & & & K10-D-42A & Yes \\
\hline \multirow{13}{*}{ С3C } & & \multirow{10}{*}{$5 / 25 / 05$} & $06: 17$ & \multirow{13}{*}{232.88} & & K10-D-56A & Yes \\
\hline & & & 06:30 & & & K10-D-56B & Trace \\
\hline & & & 07:01 & & & K10-D-56C & Yes \\
\hline & & & $07: 45$ & & & K10-D-57A & Yes \\
\hline & & & 08:58 & & & K10-D-57B & Yes \\
\hline & & & 11:07 & & & K10-D-57C & Yes \\
\hline & & & $14: 03$ & & & K10-D-58A & Yes \\
\hline & & & $21: 02$ & & & K10-D-63A & Yes \\
\hline & & & $23: 24$ & & & K10-D-63B & No \\
\hline & & & $23: 55$ & & & K10-D-63C & No \\
\hline & & \multirow{3}{*}{$5 / 26 / 05$} & $00: 30$ & & & K10-D-63D & Yes \\
\hline & & & $02: 37$ & & & K10-D-64A & Yes \\
\hline & & & 04:09 & & & K10-D-64B & No \\
\hline
\end{tabular}

- Empty data field 
Table 4.1. Summary of DM100 Test Conditions and Results.

\begin{tabular}{|c|c|c|c|c|c|c|c|}
\hline \multicolumn{2}{|r|}{ Test } & 1 & $2 \mathrm{~A}$ & $2 \mathrm{~B}$ & $2 \mathrm{C}$ & $2 \mathrm{D}$ & $2 \mathrm{E}$ \\
\hline \multirow{4}{*}{ Time } & Feed Start & $\begin{array}{l}6 / 2 / 05 \\
21: 45 \\
\end{array}$ & $\begin{array}{l}6 / 6 / 05 \\
13: 00 \\
\end{array}$ & $\begin{array}{l}6 / 7 / 05 \\
12: 05 \\
\end{array}$ & $\begin{array}{l}6 / 7 / 05 \\
19: 45 \\
\end{array}$ & $\begin{array}{l}6 / 8 / 05 \\
14: 14\end{array}$ & $\begin{array}{c}6 / 9 / 05 \\
12: 34\end{array}$ \\
\hline & Feed End & $\begin{array}{c}6 / 6 / 05 \\
12: 00\end{array}$ & $\begin{array}{l}6 / 7 / 05 \\
12: 05\end{array}$ & $\begin{array}{l}6 / 7 / 05 \\
19: 00\end{array}$ & $\begin{array}{l}6 / 8 / 05 \\
14: 05\end{array}$ & $\begin{array}{l}6 / 9 / 05 \\
12: 24\end{array}$ & $\begin{array}{c}6 / 10 / 05 \\
6: 01\end{array}$ \\
\hline & Water Feeding (hr) & 1.0 & 0 & 0 & 0 & 0 & 0 \\
\hline & Net Slurry Feeding (hr) & 85.3 & 23.1 & 6.9 & 18.3 & 22.2 & 17.4 \\
\hline \multicolumn{2}{|r|}{ Target Glass Temperature $\left(\mathrm{C}^{\circ}\right)$} & 1150 & 1175 & 1175 & 1175 & 1175 & 1175 \\
\hline \multirow{3}{*}{ Feed } & $\mathrm{wt} \% \mathrm{SO}_{3}$ as glass & 1.1 & 1.3 & 1.3 & 1.23 & 1.15 & 1.15 \\
\hline & Inclusion of waste organic compounds in 0.5 Sugar Ratio & Yes & Yes & Yes & Yes & Yes & No \\
\hline & Feed Used (kg) & 1671 & 605 & 138 & 373 & 441 & 357 \\
\hline \multicolumn{2}{|r|}{ Average Production Rate (kg/m²/day) } & 2158 & 2875 & 2206 & 2245 & 2187 & 2259 \\
\hline \multicolumn{2}{|r|}{ Steady State Production Rate (kg/m²/day) } & 2250 & 3300 & 2250 & 2250 & 2250 & 2250 \\
\hline \multicolumn{2}{|r|}{ Average Bubbling Rate (lpm) } & 17.1 & 17.1 & 10.7 & 11.0 & 12.2 & 6.8 \\
\hline \multirow{5}{*}{ Product } & Secondary Phases on Melt Surface at Test End & No & Yes & Yes & Yes & No & No \\
\hline & Secondary Phases in Poured Glass at Test End & No & Yes & Yes & Yes & Yes & Yes \\
\hline & $\% \mathrm{Fe}^{+2} /$ Total Iron & 4.0 & NA & NA & NA & 4.0 & 30.5 \\
\hline & Measured wt\% $\mathrm{SO}_{3}$ & 1.05 & 1.21 & 1.21 & 1.16 & 1.10 & 1.00 \\
\hline & \% Feed Sulfur in Glass Product & 95 & 93 & 93 & 94 & 96 & 87 \\
\hline \multicolumn{2}{|r|}{ \% Feed Sulfur in Particulate Emissions } & 4.0 & NA & NA & NA & NA & 6.2 \\
\hline \multicolumn{2}{|r|}{ \% Feed Sulfur in Gaseous Emissions } & 0.2 & NA & NA & NA & NA & 5.2 \\
\hline
\end{tabular}


The Catholic University of America Vitreous State Laboratory
LAW Envelope C Glass Formulation Testing

to Increase Waste Loading

Final Report, VSL-05R5900-1, Rev. 0

Table 4.2. Summary of Measured DM100 Parameters.

\begin{tabular}{|c|c|c|c|c|c|c|c|c|c|c|c|}
\hline \multirow{2}{*}{\multicolumn{3}{|c|}{-}} & \multicolumn{3}{|c|}{ Test 1} & \multicolumn{3}{|c|}{ Test 2a } & \multicolumn{3}{|c|}{ Test 2b } \\
\hline & & & AVG & MIN & MAX & AVG & MIN & MAX & AVG & MIN & MAX \\
\hline \multirow{12}{*}{$\begin{array}{c}\mathrm{T} \\
\mathrm{E} \\
\mathrm{M} \\
\mathrm{P} \\
\mathrm{E} \\
\mathrm{R} \\
\mathrm{A} \\
\mathrm{T} \\
\mathrm{U} \\
\mathrm{R} \\
\mathrm{E} \\
\text { (C) }\end{array}$} & \multirow{3}{*}{ Electrode } & East & 1121 & 1109 & 1144 & 1142 & 1083 & 1164 & 1148 & 1142 & 1160 \\
\hline & & West & 1077 & 997 & 1097 & 1088 & 1031 & 1102 & 1087 & 1080 & 1107 \\
\hline & & Bottom & 917 & 893 & 923 & 949 & 903 & 965 & 948 & 944 & 963 \\
\hline & \multirow{4}{*}{ Glass } & 19" from bottom & 1015 & 669 & 1079 & 1037 & 921 & 1110 & 1008 & 920 & 1087 \\
\hline & & 16" from bottom & 1134 & 1076 & 1185 & 1153 & 1079 & 1186 & 1155 & 1136 & 1166 \\
\hline & & 10" from bottom & 1150 & 1124 & 1185 & 1171 & 1097 & 1196 & 1176 & 1166 & 1193 \\
\hline & & 4" from bottom & 1151 & 1108 & 1181 & 1172 & 1065 & 1195 & 1174 & 1166 & 1190 \\
\hline & \multirow{2}{*}{ Plenum } & Exposed & 558 & 476 & 875 & 592 & 520 & 815 & 566 & 537 & 630 \\
\hline & & Thermowell & 545 & 492 & 862 & 575 & 523 & 752 & 551 & 527 & 605 \\
\hline & \multicolumn{2}{|c|}{ Discharge Chamber } & 1029 & 987 & 1061 & 1008 & 840 & 1062 & 1001 & 975 & 1033 \\
\hline & \multicolumn{2}{|c|}{ Film Cooler Outlet } & 298 & 175 & 358 & 287 & 187 & 323 & 284 & 279 & 301 \\
\hline & \multicolumn{2}{|c|}{ Transition Line Outlet } & 292 & 204 & 348 & 289 & 179 & 308 & 288 & 282 & 294 \\
\hline \multicolumn{3}{|c|}{ Lance Bubbling (lpm) } & 17.1 & 1.9 & 22.9 & 17.1 & 1.6 & 18.8 & 10.7 & 8.1 & 18.6 \\
\hline \multicolumn{3}{|c|}{ Melter Pressure (inches water) } & -1.26 & -5.08 & 0.34 & -1.21 & -4.34 & 1.55 & -1.04 & -2.55 & 0.11 \\
\hline \multicolumn{3}{|c|}{ Electrode Voltage (V) } & 44.36 & 37.05 & 49.49 & 46.54 & 39.20 & 49.56 & 40.43 & 36.61 & 48.11 \\
\hline \multicolumn{3}{|c|}{ Total Power $(\mathrm{kW})$} & 23.71 & 17.26 & 25.39 & 29.50 & 21.47 & 31.46 & 23.85 & 20.78 & 31.35 \\
\hline
\end{tabular}

- Empty data field 
The Catholic University of America Vitreous State Laboratory
LAW Envelope C Glass Formulation Testing

to Increase Waste Loading

Final Report, VSL-05R5900-1, Rev. 0

Table 4.2. Summary of Measured DM100 Parameters, (continued).

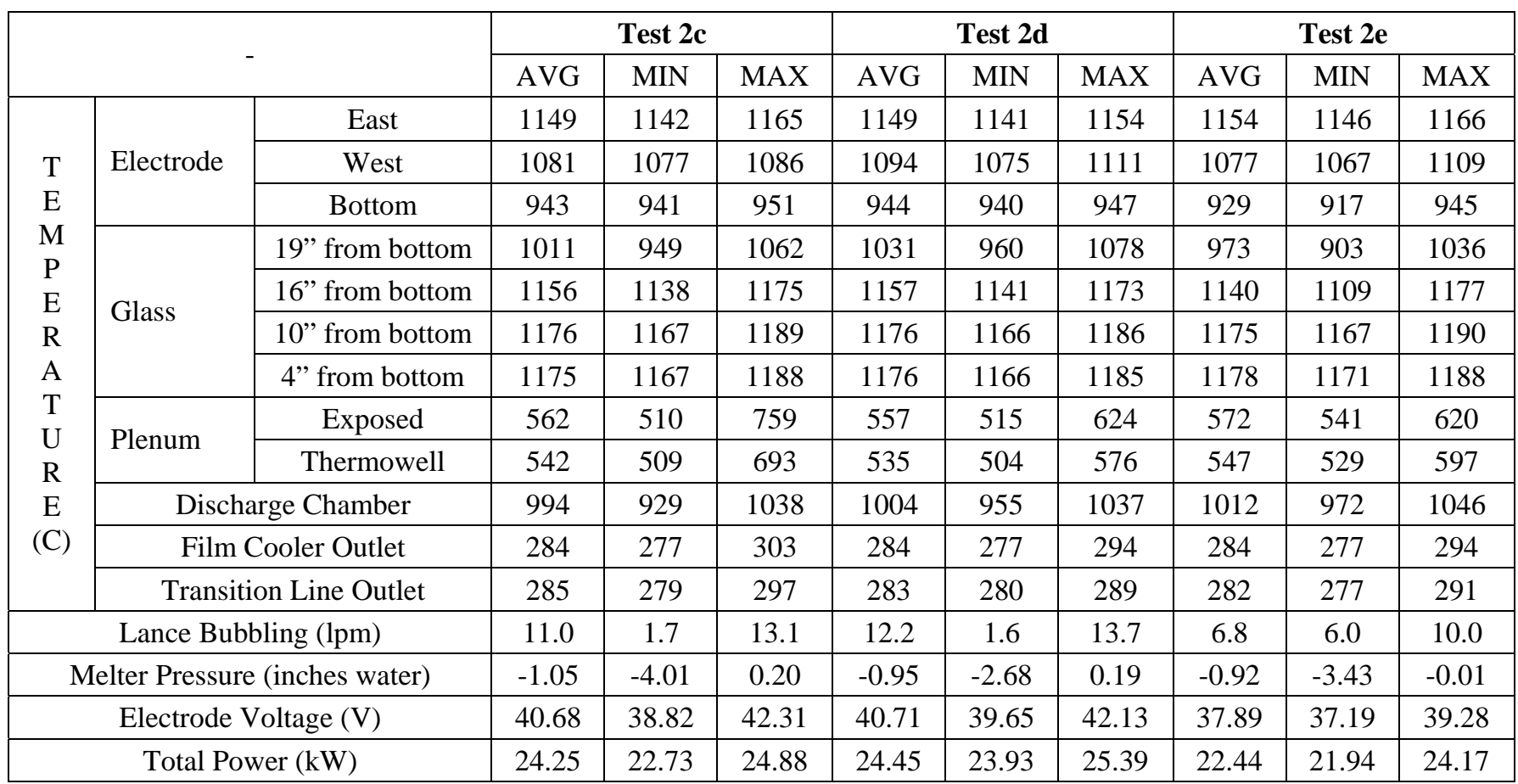

- Empty data field 
Table 5.1. Listing of DM100 Glasses Discharged, Masses, and Analysis Performed.

\begin{tabular}{|c|c|c|c|c|c|c|c|c|}
\hline Test & $\begin{array}{c}\text { Target } \mathrm{SO}_{3} \\
\text { (wt\%) }\end{array}$ & $\mathbf{T}\left({ }^{\circ} \mathrm{C}\right)$ & Date & Name & Analysis & $\begin{array}{c}\text { Mass } \\
\text { (kg) }\end{array}$ & $\begin{array}{l}\text { Cumulative } \\
\text { Mass (kg) }\end{array}$ & $\begin{array}{c}\text { Secondary } \\
\text { Sulfate }\end{array}$ \\
\hline \multirow{42}{*}{1} & \multirow{42}{*}{1.10} & \multirow{42}{*}{1150} & \multirow{19}{*}{$6 / 3 / 05$} & WVY-G-34A & - & - & - & - \\
\hline & & & & WVY-G-36A & XRF & 21.72 & 21.72 & No \\
\hline & & & & WVY-G-36B & - & - & - & - \\
\hline & & & & WVY-G-37A & XRF & 25.54 & 47.26 & No \\
\hline & & & & WVY-G-38A & - & - & - & - \\
\hline & & & & WVY-G-38B & XRF & 22.54 & 69.80 & No \\
\hline & & & & WVY-G-38C & - & - & - & - \\
\hline & & & & WVY-G-44A & XRF & 24.96 & 94.76 & Yes \\
\hline & & & & WVY-G-45A & - & - & - & - \\
\hline & & & & WVY-G-45B & XRF & 25.92 & 120.68 & Yes \\
\hline & & & & WVY-G-46A & - & - & - & - \\
\hline & & & & WVY-G-46B & $\mathrm{XRF}$ & 21.66 & 142.34 & No \\
\hline & & & & WVY-G-46C & - & - & - & - \\
\hline & & & & WVY-G-47A & XRF & 26.50 & 168.84 & No \\
\hline & & & & WVY-G-47B & - & - & - & - \\
\hline & & & & WVY-G-47C & XRF & 25.50 & 194.34 & No \\
\hline & & & & WVY-G-49A & - & - & - & - \\
\hline & & & & WVY-G-49B & XRF & 27.06 & 221.40 & Yes \\
\hline & & & & WVY-G-53A & - & - & - & - \\
\hline & & & \multirow{19}{*}{$6 / 4 / 05$} & WVY-G-53B & XRF & 23.24 & 244.64 & No \\
\hline & & & & WVY-G-54A & - & - & - & - \\
\hline & & & & WVY-G-54B & $\mathrm{XRF}$ & 24.86 & 269.50 & No \\
\hline & & & & WVY-G-56A & - & - & - & - \\
\hline & & & & WVY-G-57A & XRF & 24.30 & 293.80 & No \\
\hline & & & & WVY-G-57B & - & - & - & - \\
\hline & & & & WVY-G-60A & $\mathrm{XRF}$ & 24.10 & 317.90 & No \\
\hline & & & & WVY-G-60B & - & - & - & - \\
\hline & & & & WVY-G-60C & XRF & 23.16 & 341.06 & No \\
\hline & & & & WVY-G-61A & - & - & - & - \\
\hline & & & & WVY-G-61B & XRF & 21.10 & 362.16 & No \\
\hline & & & & WVY-G-61C & - & - & - & - \\
\hline & & & & WVY-G-63A & XRF & 24.50 & 386.66 & No \\
\hline & & & & WVY-G-63B & - & - & - & - \\
\hline & & & & WVY-G-64A & $\mathrm{XRF}$ & 23.80 & 410.46 & No \\
\hline & & & & WVY-G-64B & - & - & - & - \\
\hline & & & & WVY-G-66A & XRF & 24.04 & 434.50 & No \\
\hline & & & & WVY-G-66B & - & - & - & - \\
\hline & & & & WVY-G-70A & $\mathrm{XRF}$ & 29.52 & 464.02 & No \\
\hline & & & \multirow{4}{*}{$6 / 5 / 05$} & WVY-G-71A & - & - & - & - \\
\hline & & & & WVY-G-71B & XRF & 21.86 & 485.88 & No \\
\hline & & & & WVY-G-72A & - & - & - & - \\
\hline & & & & WVY-G-72B & XRF & 22.16 & 508.04 & No \\
\hline
\end{tabular}

- Empty data field 
Table 5.1. Listing of DM100 Glasses Discharged, Masses, and Analysis Performed (continued).

\begin{tabular}{|c|c|c|c|c|c|c|c|c|}
\hline Test & $\begin{array}{c}\text { Target } \mathrm{SO}_{3} \\
(\mathrm{wt} \%)\end{array}$ & $\mathrm{T}\left({ }^{\circ} \mathrm{C}\right)$ & Date & Name & Analysis & $\begin{array}{c}\text { Mass } \\
(\mathrm{kg})\end{array}$ & $\begin{array}{c}\text { Cumulative } \\
\text { Mass (kg) }\end{array}$ & $\begin{array}{c}\text { Secondary } \\
\text { Sulfate } \\
\end{array}$ \\
\hline \multirow{26}{*}{1} & \multirow{26}{*}{1.10} & \multirow{26}{*}{1150} & \multirow{15}{*}{$6 / 5 / 05$} & WVY-G-74A & - & - & - & - \\
\hline & & & & WVY-G-74B & XRF & 19.98 & 528.02 & No \\
\hline & & & & WVY-G-77A & - & - & - & - \\
\hline & & & & WVY-G-77B & XRF & 23.36 & 551.38 & No \\
\hline & & & & WVY-G-77C & - & - & - & - \\
\hline & & & & WVY-G-78A & XRF & 24.04 & 575.42 & No \\
\hline & & & & WVY-G-78B & - & - & - & - \\
\hline & & & & WVY-G-78C & XRF & 27.58 & 603.00 & Yes \\
\hline & & & & WVY-G-81A & - & - & - & - \\
\hline & & & & WVY-G-81B & $\mathrm{XRF}$ & 24.34 & 627.34 & No \\
\hline & & & & WVY-G-81C & - & - & - & - \\
\hline & & & & WVY-G-82A & XRF & 22.28 & 649.62 & No \\
\hline & & & & WVY-G-82B & - & - & - & - \\
\hline & & & & WVY-G-86A & $\mathrm{XRF}$ & 27.08 & 676.70 & No \\
\hline & & & & WVY-G-86B & - & - & - & - \\
\hline & & & \multirow{19}{*}{ 6/6/05 } & WVY-G-87A & $\mathrm{XRF}$ & 23.08 & 699.78 & No \\
\hline & & & & WVY-G-87B & - & - & - & - \\
\hline & & & & WVY-G-88A & XRF & 22.18 & 721.96 & No \\
\hline & & & & WVY-G-88B & - & - & - & - \\
\hline & & & & WVY-G-88C & $\mathrm{XRF}$ & 22.74 & 744.70 & No \\
\hline & & & & WVY-G-93A & - & - & - & - \\
\hline & & & & WVY-G-93B & $\mathrm{XRF}$ & 19.78 & 764.48 & No \\
\hline & & & & WVY-G-93C & - & - & - & - \\
\hline & & & & WVY-G-94A & XRF & 25.54 & 790.02 & No \\
\hline & & & & WVY-G-94B & - & - & - & - \\
\hline & & & & WVY-G-95A* & $\begin{array}{c}\text { XRF, DCP, } \\
\mathrm{Fe}^{+2} \\
\end{array}$ & 17.86 & 807.88 & No \\
\hline \multirow{17}{*}{2} & \multirow{17}{*}{1.30} & \multirow{17}{*}{1175} & & WVY-G-101A & - & - & - & - \\
\hline & & & & WVY-G-102A & XRF & 27.84 & 835.72 & No \\
\hline & & & & WVY-G-103A & - & - & - & - \\
\hline & & & & WVY-G-103B & XRF & 36.76 & 872.48 & No \\
\hline & & & & WVY-G-104A & - & - & - & - \\
\hline & & & & WVY-G-104B & $\mathrm{XRF}$ & 30.82 & 903.30 & Yes \\
\hline & & & & WVY-G-104C & - & - & - & - \\
\hline & & & & WVY-G-104D & $\mathrm{XRF}$ & 21.98 & 925.28 & Yes \\
\hline & & & \multirow{9}{*}{$6 / 7 / 05$} & WVY-G-106A & - & - & - & - \\
\hline & & & & WVY-G-106B & XRF & 22.60 & 947.88 & Yes \\
\hline & & & & WVY-G-106C & - & - & - & \\
\hline & & & & WVY-G-106D & XRF & 22.16 & 970.04 & Yes \\
\hline & & & & WVY-G-109A & XRF & 18.82 & 988.86 & Yes \\
\hline & & & & WVY-G-109B & - & - & - & - \\
\hline & & & & WVY-G-110A & $\mathrm{XRF}$ & 22.98 & 1011.84 & Yes \\
\hline & & & & WVY-G-110B & - & - & - & - \\
\hline & & & & WVY-G-114A & XRF & 26.66 & 1038.50 & Yes \\
\hline
\end{tabular}

* Sample to be shipped to ORP; - Empty data field 
Table 5.1. List of Glass Discharged, Masses, and Analysis Performed (continued).

\begin{tabular}{|c|c|c|c|c|c|c|c|c|}
\hline Test & $\begin{array}{c}\text { Target } \mathrm{SO}_{3} \\
(\mathrm{wt} \%)\end{array}$ & $\begin{array}{c}\mathbf{T} \\
\left({ }^{\circ} \mathrm{C}\right)\end{array}$ & Date & Name & Analysis & $\begin{array}{c}\text { Mass } \\
(\mathrm{kg})\end{array}$ & $\begin{array}{c}\text { Cumulative } \\
\text { Mass (kg) }\end{array}$ & $\begin{array}{c}\text { Secondary } \\
\text { Sulfate }\end{array}$ \\
\hline \multirow{42}{*}{2} & \multirow{9}{*}{1.30} & \multirow{42}{*}{1175} & \multirow{11}{*}{$6 / 7 / 05$} & WVY-G-115A & - & - & - & - \\
\hline & & & & WVY-G-115B & XRF & 32.60 & 1071.10 & Yes \\
\hline & & & & WVY-G-115C & - & - & - & - \\
\hline & & & & WVY-G-116A & XRF & 30.42 & 1101.52 & Yes \\
\hline & & & & WVY-G-117A & - & - & - & - \\
\hline & & & & WVY-G-121A & XRF & 28.60 & 1130.12 & Yes \\
\hline & & & & WVY-G-121B & - & - & - & - \\
\hline & & & & WVY-G-121C & XRF & 28.34 & 1158.46 & Yes \\
\hline & & & & WVY-G-122A & - & - & - & - \\
\hline & \multirow{13}{*}{1.23} & & & WVY-G-124A & XRF & 28.34 & 1186.80 & Yes \\
\hline & & & & WVY-G-124B & - & - & - & - \\
\hline & & & \multirow{17}{*}{$6 / 8 / 05$} & WVY-G-124C & XRF & 25.06 & 1211.86 & Yes \\
\hline & & & & WVY-G-126A & - & - & - & - \\
\hline & & & & WVY-G-126B & XRF & 25.18 & 1237.04 & Yes \\
\hline & & & & WVY-G-127A & - & - & - & - \\
\hline & & & & WVY-G-127B & XRF & 26.84 & 1263.88 & Yes \\
\hline & & & & WVY-G-127C & - & - & - & - \\
\hline & & & & WVY-G-130A & XRF & 29.60 & 1293.48 & Yes \\
\hline & & & & WVY-G-130B & - & - & - & - \\
\hline & & & & WVY-G-130C & XRF & 21.66 & 1315.14 & Yes \\
\hline & & & & WVY-G-131A & - & - & - & - \\
\hline & & & & WVY-G-131B & XRF, DCP & 23.70 & 1338.84 & Yes \\
\hline & \multirow{16}{*}{1.15} & & & WVY-G-137A & - & - & - & - \\
\hline & & & & WVY-G-137B & XRF & 36.70 & 1375.54 & Yes \\
\hline & & & & WVY-G-137C & - & - & - & - \\
\hline & & & & WVY-G-138A & XRF & 24.64 & 1400.18 & Yes \\
\hline & & & & WVY-G-138B & - & - & - & - \\
\hline & & & & WVY-G-138C & XRF & 25.56 & 1425.74 & Yes \\
\hline & & & \multirow{14}{*}{$6 / 9 / 05$} & WVY-G-138D & - & - & - & - \\
\hline & & & & WVY-G-140A & XRF & 27.58 & 1453.32 & Yes \\
\hline & & & & WVY-G-141A & - & - & - & - \\
\hline & & & & WVY-G-141B & XRF & 25.80 & 1479.12 & Yes \\
\hline & & & & WVY-G-141C & - & - & - & - \\
\hline & & & & WVY-G-146A & XRF & 23.30 & 1502.42 & Yes \\
\hline & & & & WVY-G-146B & - & - & - & - \\
\hline & & & & WVY-G-146C & XRF & 25.68 & 1528.10 & Yes \\
\hline & & & & WVY-G-147A & XRF & 13.02 & 1541.12 & Yes \\
\hline & & & & WVY-G-147B & XRF & 11.78 & 1552.90 & Yes \\
\hline & \multirow{4}{*}{1.15} & & & WVY-G-150A & $\begin{array}{c}\text { XRF, DCP, } \\
\mathrm{Fe}^{+2} \\
\end{array}$ & 11.80 & 1564.70 & Yes \\
\hline & & & & WVY-G-154A & XRF & 11.10 & 1575.80 & Yes \\
\hline & & & & WVY-G-154B & - & - & - & - \\
\hline & & & & WVY-G-154C & XRF & 24.18 & 1599.98 & Yes \\
\hline
\end{tabular}

- Empty data field 
The Catholic University of America Vitreous State Laboratory
LAW Envelope C Glass Formulation Testing to Increase Waste Loading Final Report, VSL-05R5900-1, Rev. 0

Table 5.1. List of Glass Discharged, Masses, and Analysis Performed (continued).

\begin{tabular}{|c|c|c|c|c|c|c|c|c|}
\hline Test & Target $\mathrm{SO}_{3}(\mathrm{wt} \%)$ & $\mathbf{T}\left({ }^{\circ} \mathrm{C}\right)$ & Date & Name & Analysis & $\begin{array}{c}\text { Mass } \\
\text { (kg) }\end{array}$ & $\begin{array}{c}\text { Cumulative } \\
\text { Mass (kg) }\end{array}$ & $\begin{array}{c}\text { Secondary } \\
\text { Sulfate }\end{array}$ \\
\hline \multirow{9}{*}{2} & \multirow{9}{*}{1.15} & \multirow{9}{*}{1175} & \multirow{4}{*}{ 6/9/05 } & WVY-G-155A & - & - & - & - \\
\hline & & & & WVY-G-155B & XRF & 25.60 & 1625.58 & Yes \\
\hline & & & & WVZ-G-5A & - & - & - & - \\
\hline & & & & WVZ-G-5B & XRF & 28.86 & 1654.44 & Yes \\
\hline & & & \multirow{5}{*}{ 6/10/05 } & WVZ-G-5C & XRF, DCP & 13.64 & 1668.08 & Yes \\
\hline & & & & WVZ-G-10A & XRF & 14.18 & 1682.26 & Yes \\
\hline & & & & WVZ-G-10B & XRF & 13.52 & 1695.78 & Yes \\
\hline & & & & WVZ-G-10C & XRF & 15.30 & 1711.08 & Yes \\
\hline & & & & WVZ-G-11A* & $\begin{array}{c}\text { XRF, DCP, } \\
\mathrm{Fe}^{+2}\end{array}$ & 5.48 & 1716.56 & Yes \\
\hline
\end{tabular}

* Sample to be shipped to ORP

- Empty data field 
Table 5.2. XRF Analyzed Composition for DM100 Discharged Glass Samples (wt\%).

\begin{tabular}{|c|c|c|c|c|c|c|c|c|c|c|c|c|c|c|c|c|}
\hline Test & \multicolumn{16}{|c|}{1} \\
\hline $\begin{array}{c}\text { Glass } \\
\text { Temperature }\end{array}$ & \multicolumn{16}{|c|}{$1150{ }^{\circ} \mathrm{C}$} \\
\hline Target $\mathrm{SO}_{3}$ & \multicolumn{16}{|c|}{1.10} \\
\hline Glass (kg) & \multirow[b]{2}{*}{ Target } & 21.72 & 47.26 & 69.8 & 94.76 & 120.68 & 142.34 & 168.84 & 194.34 & 221.40 & 244.64 & 269.50 & 293.8 & 317.9 & 341.06 & 362.16 \\
\hline Constituent & & $\begin{array}{l}\text { WVY- } \\
\text { G-36A }\end{array}$ & $\begin{array}{l}\text { WVY- } \\
\text { G-37A }\end{array}$ & $\begin{array}{l}\text { WVY- } \\
\text { G-38B }\end{array}$ & $\begin{array}{l}\text { WVY- } \\
\text { G-44A }\end{array}$ & $\begin{array}{l}\text { WVY- } \\
\text { G-45B }\end{array}$ & $\begin{array}{l}\text { WVY- } \\
\text { G-46B }\end{array}$ & $\begin{array}{l}\text { WVY- } \\
\text { G-47A }\end{array}$ & $\begin{array}{l}\text { WVY- } \\
\text { G-47C }\end{array}$ & $\begin{array}{l}\text { WVY- } \\
\text { G-49B }\end{array}$ & $\begin{array}{l}\text { WVY- } \\
\text { G-53B }\end{array}$ & $\begin{array}{l}\text { WVY- } \\
\text { G-54B }\end{array}$ & $\begin{array}{l}\text { WVY- } \\
\text { G-57A }\end{array}$ & $\begin{array}{l}\text { WVY- } \\
\text { G-60A }\end{array}$ & $\begin{array}{l}\text { WVY- } \\
\text { G-60C }\end{array}$ & $\begin{array}{l}\text { WVY- } \\
\text { G-61B }\end{array}$ \\
\hline $\mathrm{Al}_{2} \mathrm{O}_{3}$ & 10.16 & 7.45 & 8.05 & 8.29 & 8.42 & 8.53 & 8.93 & 9.16 & 9.13 & 9.43 & 9.43 & 9.56 & 9.63 & 9.76 & 9.76 & 9.67 \\
\hline $\mathrm{B}_{2} \mathrm{O}_{3} *$ & 13.68 & 10.60 & 11.19 & 11.62 & 12.01 & 12.33 & 12.55 & 12.78 & 12.95 & 13.10 & 13.20 & 13.29 & 13.36 & 13.42 & 13.47 & 13.50 \\
\hline $\mathrm{CaO}$ & 8.02 & 2.20 & 2.95 & 3.48 & 4.15 & 4.57 & 4.72 & 5.30 & 5.51 & 5.76 & 6.02 & 6.23 & 6.26 & 6.22 & 6.33 & 6.79 \\
\hline $\mathrm{Cl}$ & 0.65 & 0.05 & 0.15 & 0.20 & 0.26 & 0.30 & 0.32 & 0.34 & 0.37 & 0.38 & 0.39 & 0.40 & 0.40 & 0.42 & 0.41 & 0.41 \\
\hline $\mathrm{Cr}_{2} \mathrm{O}_{3}$ & 0.02 & 0.27 & 0.24 & 0.23 & 0.22 & 0.21 & 0.19 & 0.21 & 0.20 & 0.20 & 0.20 & 0.20 & 0.19 & 0.18 & 0.18 & 0.20 \\
\hline $\mathrm{F}$ & 0.19 & NA & NA & NA & NA & NA & NA & NA & NA & NA & NA & NA & NA & NA & NA & NA \\
\hline $\mathrm{Fe}_{2} \mathrm{O}_{3}$ & 1.00 & 4.81 & 4.13 & 3.83 & 3.43 & 3.07 & 2.63 & 2.54 & 2.23 & 2.04 & 1.97 & 1.82 & 1.63 & 1.48 & 1.39 & 1.50 \\
\hline I & 0.10 & $<0.01$ & $<0.01$ & 0.01 & 0.01 & 0.01 & 0.01 & 0.01 & 0.01 & $<0.01$ & 0.01 & 0.01 & 0.01 & 0.01 & 0.01 & 0.01 \\
\hline $\mathrm{K}_{2} \mathrm{O}$ & 0.15 & 2.26 & 1.90 & 1.75 & 1.51 & 1.31 & 1.18 & 1.05 & 0.94 & 0.82 & 0.77 & 0.70 & 0.66 & 0.58 & 0.54 & 0.51 \\
\hline $\mathrm{MgO}$ & 1.00 & 1.69 & 1.53 & 1.47 & 1.39 & 1.37 & 1.28 & 1.18 & 1.19 & 1.21 & 1.12 & 1.08 & 1.08 & 0.97 & 0.99 & 0.95 \\
\hline $\mathrm{MnO}$ & $\S$ & 0.01 & 0.02 & 0.02 & 0.02 & 0.02 & 0.02 & 0.02 & 0.02 & 0.02 & 0.02 & 0.02 & 0.02 & 0.02 & 0.02 & 0.01 \\
\hline $\mathrm{Na}_{2} \mathrm{O}$ & 20.00 & 18.40 & 18.40 & 18.79 & 18.77 & 19.59 & 19.64 & 19.19 & 20.08 & 19.83 & 19.90 & 19.99 & 19.86 & 20.16 & 20.62 & 19.97 \\
\hline $\mathrm{NiO}$ & 0.03 & 0.06 & 0.05 & 0.04 & 0.04 & 0.04 & 0.03 & 0.03 & 0.03 & 0.03 & 0.03 & 0.03 & 0.02 & 0.02 & 0.02 & 0.02 \\
\hline $\mathrm{P}_{2} \mathrm{O}_{5}$ & 0.27 & 0.23 & 0.24 & 0.25 & 0.29 & 0.29 & 0.32 & 0.32 & 0.33 & 0.35 & 0.33 & 0.34 & 0.35 & 0.36 & 0.36 & 0.36 \\
\hline $\mathrm{PbO}$ & 0.01 & $<0.01$ & $<0.01$ & $<0.01$ & $<0.01$ & $<0.01$ & $<0.01$ & 0.01 & $<0.01$ & $<0.01$ & $<0.01$ & 0.01 & $<0.01$ & 0.01 & $<0.01$ & $<0.01$ \\
\hline $\mathrm{SiO}_{2}$ & 36.62 & 44.39 & 43.76 & 42.46 & 41.74 & 40.70 & 41.05 & 40.01 & 39.37 & 39.24 & 38.86 & 38.59 & 39.02 & 39.13 & 38.59 & 38.21 \\
\hline $\mathrm{SO}_{3}$ & 1.10 & 0.30 & 0.43 & 0.50 & 0.60 & 0.64 & 0.72 & 0.76 & 0.79 & 0.84 & 0.85 & 0.90 & 0.93 & 0.97 & 0.97 & 1.00 \\
\hline $\mathrm{TiO}_{2}$ & $\S$ & 1.90 & 1.59 & 1.44 & 1.24 & 1.07 & 0.92 & 0.85 & 0.73 & 0.65 & 0.60 & 0.53 & 0.46 & 0.41 & 0.38 & 0.38 \\
\hline $\mathrm{V}_{2} \mathrm{O}_{5}$ & 1.00 & 0.09 & 0.24 & 0.35 & 0.49 & 0.57 & 0.62 & 0.72 & 0.77 & 0.82 & 0.87 & 0.91 & 0.92 & 0.92 & 0.94 & 1.02 \\
\hline $\mathrm{ZnO}$ & 3.00 & 2.33 & 2.32 & 2.42 & 2.53 & 2.54 & 2.38 & 2.63 & 2.60 & 2.57 & 2.67 & 2.68 & 2.59 & 2.51 & 2.54 & 2.76 \\
\hline $\mathrm{ZrO}_{2}$ & 3.00 & 2.96 & 2.80 & 2.86 & 2.87 & 2.83 & 2.51 & 2.89 & 2.74 & 2.70 & 2.77 & 2.71 & 2.59 & 2.45 & 2.47 & 2.70 \\
\hline Sum & 100.00 & 100.00 & 100.00 & 100.00 & 100.00 & 100.00 & 100.00 & 100.00 & 100.00 & 100.00 & 100.00 & 100.00 & 100.00 & 100.00 & 100.00 & 100.00 \\
\hline
\end{tabular}

$\S$ - Not a target constituent; * Target value calculated based on simple well-stirred tank model; NA - Not Analyzed 
Table 5.2. XRF Analyzed Composition for DM100 Discharged Glass Samples (wt\%) (continued).

\begin{tabular}{|c|c|c|c|c|c|c|c|c|c|c|c|c|c|c|c|c|}
\hline Test & \multicolumn{16}{|c|}{1} \\
\hline $\begin{array}{c}\text { Glass } \\
\text { Temperature }\end{array}$ & \multicolumn{16}{|c|}{$1150^{\circ} \mathrm{C}$} \\
\hline Target $\mathrm{SO}_{3}$ & \multicolumn{16}{|c|}{1.10} \\
\hline Glass (kg) & \multirow[b]{2}{*}{ Target } & 386.66 & 410.46 & 434.50 & 464.02 & 485.88 & 508.04 & 528.02 & 551.38 & 575.42 & 603.00 & 627.34 & 649.62 & 676.70 & 699.78 & 721.96 \\
\hline Constituent & & $\begin{array}{l}\text { WVY- } \\
\text { G-63A }\end{array}$ & $\begin{array}{l}\text { WVY- } \\
\text { G-64A }\end{array}$ & $\begin{array}{l}\text { WVY- } \\
\text { G-66A }\end{array}$ & $\begin{array}{l}\text { WVY- } \\
\text { G-70A }\end{array}$ & $\begin{array}{l}\text { WVY- } \\
\text { G-71B }\end{array}$ & $\begin{array}{l}\text { WVY- } \\
\text { G-72B }\end{array}$ & $\begin{array}{r}\mathrm{WVY}-\mathrm{G}- \\
74 \mathrm{~B}\end{array}$ & $\begin{array}{l}\text { WVY- } \\
\text { G-77B }\end{array}$ & $\begin{array}{l}\text { WVY- } \\
\text { G-78A }\end{array}$ & $\begin{array}{l}\text { WVY- } \\
\text { G-78C }\end{array}$ & $\begin{array}{l}\text { WVY- } \\
\text { G-81B }\end{array}$ & $\begin{array}{l}\text { WVY- } \\
\text { G-82A }\end{array}$ & $\begin{array}{l}\text { WVY- } \\
\text { G-86A }\end{array}$ & $\begin{array}{l}\text { WVY- } \\
\text { G-87A }\end{array}$ & $\begin{array}{l}\text { WVY- } \\
\text { G-88A }\end{array}$ \\
\hline $\mathrm{Al}_{2} \mathrm{O}_{3}$ & 10.16 & 9.71 & 9.96 & 9.84 & 9.83 & 9.94 & 9.77 & 10.04 & 10.20 & 10.07 & 10.07 & 10.10 & 11.87 & 10.04 & 10.01 & 10.09 \\
\hline $\mathrm{B}_{2} \mathrm{O}_{3} *$ & 13.68 & 13.54 & 13.56 & 13.59 & 13.61 & 13.62 & 13.63 & 13.64 & 13.65 & 13.65 & 13.66 & 13.66 & 13.67 & 13.67 & 13.67 & 13.68 \\
\hline $\mathrm{CaO}$ & 8.02 & 6.62 & 6.70 & 7.02 & 7.16 & 7.14 & 7.12 & 6.69 & 6.61 & 7.19 & 6.92 & 7.04 & 6.64 & 6.93 & 7.02 & 6.94 \\
\hline $\mathrm{Cl}$ & 0.65 & 0.42 & 0.43 & 0.43 & 0.44 & 0.44 & 0.44 & 0.43 & 0.42 & 0.45 & 0.43 & 0.43 & 0.42 & 0.43 & 0.43 & 0.42 \\
\hline $\mathrm{Cr}_{2} \mathrm{O}_{3}$ & 0.02 & 0.19 & 0.19 & 0.20 & 0.20 & 0.20 & 0.19 & 0.18 & 0.17 & 0.19 & 0.18 & 0.18 & 0.18 & 0.18 & 0.18 & 0.18 \\
\hline $\mathrm{F}$ & 0.19 & NA & NA & NA & NA & NA & NA & NA & NA & NA & NA & NA & NA & NA & NA & NA \\
\hline $\mathrm{Fe}_{2} \mathrm{O}_{3}$ & 1.00 & 1.38 & 1.28 & 1.30 & 1.29 & 1.25 & 1.19 & 1.09 & 1.03 & 1.15 & 1.05 & 1.06 & 0.99 & 1.03 & 1.06 & 1.05 \\
\hline I & 0.10 & 0.01 & 0.01 & 0.01 & 0.01 & 0.01 & 0.01 & $<0.01$ & $<0.01$ & 0.01 & $<0.01$ & 0.01 & 0.01 & 0.01 & $<0.01$ & 0.01 \\
\hline $\mathrm{K}_{2} \mathrm{O}$ & 0.15 & 0.47 & 0.47 & 0.44 & 0.44 & 0.41 & 0.39 & 0.39 & 0.38 & 0.37 & 0.34 & 0.37 & 0.33 & 0.33 & 0.32 & 0.33 \\
\hline $\mathrm{MgO}$ & 1.00 & 1.03 & 0.99 & 0.96 & 0.94 & 0.95 & 0.97 & 0.97 & 0.93 & 0.93 & 0.91 & 1.01 & 0.92 & 1.00 & 0.93 & 1.04 \\
\hline $\mathrm{MnO}$ & $\S$ & 0.01 & 0.02 & 0.02 & 0.02 & 0.01 & 0.01 & 0.01 & 0.01 & 0.01 & 0.01 & 0.01 & 0.01 & 0.01 & 0.01 & 0.01 \\
\hline $\mathrm{Na}_{2} \mathrm{O}$ & 20.00 & 20.90 & 20.41 & 20.21 & 19.91 & 19.73 & 20.41 & 20.77 & 20.93 & 19.82 & 21.26 & 20.27 & 20.19 & 21.08 & 20.76 & 21.04 \\
\hline $\mathrm{NiO}$ & 0.03 & 0.02 & 0.02 & 0.02 & 0.02 & 0.03 & 0.02 & 0.02 & 0.01 & 0.02 & 0.02 & 0.02 & 0.02 & 0.02 & 0.02 & 0.02 \\
\hline $\mathrm{P}_{2} \mathrm{O}_{5}$ & 0.27 & 0.36 & 0.38 & 0.38 & 0.38 & 0.38 & 0.38 & 0.38 & 0.39 & 0.39 & 0.38 & 0.38 & 0.37 & 0.37 & 0.39 & 0.36 \\
\hline $\mathrm{PbO}$ & 0.01 & 0.01 & 0.01 & $<0.01$ & 0.01 & 0.01 & 0.01 & 0.01 & 0.01 & 0.01 & 0.01 & 0.01 & 0.01 & $<0.01$ & $<0.01$ & $<0.01$ \\
\hline $\mathrm{SiO}_{2}$ & 36.62 & 37.75 & 38.07 & 37.64 & 37.72 & 37.83 & 37.49 & 38.15 & 38.26 & 37.78 & 37.27 & 37.90 & 37.26 & 37.43 & 37.50 & 37.26 \\
\hline $\mathrm{SO}_{3}$ & 1.10 & 0.98 & 1.00 & 1.03 & 1.04 & 1.05 & 1.05 & 1.02 & 1.03 & 1.08 & 1.06 & 1.06 & 1.03 & 1.05 & 1.05 & 1.04 \\
\hline $\mathrm{TiO}_{2}$ & $\S$ & 0.34 & 0.32 & 0.32 & 0.30 & 0.29 & 0.28 & 0.25 & 0.23 & 0.25 & 0.23 & 0.23 & 0.22 & 0.22 & 0.22 & 0.22 \\
\hline $\mathrm{V}_{2} \mathrm{O}_{5}$ & 1.00 & 0.99 & 1.02 & 1.07 & 1.11 & 1.11 & 1.10 & 1.01 & 1.00 & 1.10 & 1.07 & 1.07 & 1.00 & 1.07 & 1.08 & 1.07 \\
\hline $\mathrm{ZnO}$ & 3.00 & 2.65 & 2.65 & 2.83 & 2.84 & 2.84 & 2.82 & 2.54 & 2.46 & 2.81 & 2.64 & 2.66 & 2.50 & 2.61 & 2.69 & 2.66 \\
\hline $\mathrm{ZrO}_{2}$ & 3.00 & 2.60 & 2.53 & 2.71 & 2.74 & 2.74 & 2.71 & 2.41 & 2.27 & 2.70 & 2.50 & 2.53 & 2.38 & 2.52 & 2.67 & 2.60 \\
\hline Sum & 100.00 & 100.00 & 100.00 & 100.00 & 100.00 & 100.00 & 100.00 & 100.00 & 100.00 & 100.00 & 100.00 & 100.00 & 100.00 & 100.00 & 100.00 & 100.00 \\
\hline
\end{tabular}


Table 5.2. XRF Analyzed Composition for DM100 Discharged Glass Samples (wt \%) (continued).

\begin{tabular}{|c|c|c|c|c|c|c|c|c|c|c|c|c|c|c|}
\hline Test & \multicolumn{5}{|c|}{1} & \multicolumn{9}{|c|}{2} \\
\hline $\begin{array}{c}\text { Glass } \\
\text { Temperature }\end{array}$ & \multicolumn{5}{|c|}{$1150^{\circ} \mathrm{C}$} & \multicolumn{9}{|c|}{$1175^{\circ} \mathrm{C}$} \\
\hline Target SO3 & \multicolumn{5}{|c|}{1.10} & \multicolumn{9}{|c|}{1.30} \\
\hline Glass (kg) & \multirow[b]{2}{*}{ Target } & 744.70 & 764.48 & 790.02 & 807.88 & \multirow[b]{2}{*}{ Target } & 835.72 & 872.48 & 903.30 & 925.28 & 947.88 & 970.04 & 988.86 & 1011.84 \\
\hline Constituent & & $\begin{array}{l}\text { WVY- } \\
\text { G-88C }\end{array}$ & $\begin{array}{l}\text { WVY- } \\
\text { G-93B }\end{array}$ & $\begin{array}{l}\text { WVY- } \\
\text { G-94A }\end{array}$ & $\begin{array}{l}\text { WVY- } \\
\text { G-95A }\end{array}$ & & \begin{tabular}{|c|} 
WVY- \\
G-102A
\end{tabular} & $\begin{array}{l}\text { WVY- } \\
\text { G-103B }\end{array}$ & \begin{tabular}{|l|} 
WVY- \\
G-104B
\end{tabular} & $\begin{array}{l}\text { WVY- } \\
\text { G-104D }\end{array}$ & $\begin{array}{l}\text { WVY- } \\
\text { G-106B }\end{array}$ & $\begin{array}{l}\text { WVY- } \\
\text { G-106D }\end{array}$ & \begin{tabular}{|l} 
WVY- \\
G-109A
\end{tabular} & $\begin{array}{l}\text { WVY- } \\
\text { G-110A }\end{array}$ \\
\hline $\mathrm{Al}_{2} \mathrm{O}_{3}$ & 10.16 & 9.93 & 9.99 & 10.06 & 10.00 & 10.14 & 9.92 & 10.08 & 10.02 & 9.96 & 9.94 & 9.82 & 9.83 & 9.97 \\
\hline $\mathrm{B}_{2} \mathrm{O}_{3} *$ & 13.68 & 13.68 & 13.68 & 13.68 & 13.68 & 13.66 & 13.68 & 13.67 & 13.67 & 13.67 & 13.66 & 13.66 & 13.66 & 13.66 \\
\hline $\mathrm{CaO}$ & 8.02 & 6.98 & 7.20 & 7.08 & 7.08 & 8.00 & 7.14 & 7.00 & 7.05 & 6.94 & 6.94 & 7.20 & 7.21 & 6.96 \\
\hline $\mathrm{Cl}$ & 0.65 & 0.42 & 0.44 & 0.43 & 0.42 & 0.65 & 0.41 & 0.42 & 0.42 & 0.42 & 0.42 & 0.42 & 0.44 & 0.44 \\
\hline $\mathrm{Cr}_{2} \mathrm{O}_{3}$ & 0.02 & 0.17 & 0.19 & 0.18 & 0.17 & 0.02 & 0.18 & 0.17 & 0.16 & 0.15 & 0.15 & 0.15 & 0.15 & 0.14 \\
\hline $\mathrm{F}$ & 0.19 & NA & NA & NA & NA & 0.19 & NA & NA & NA & NA & NA & NA & NA & NA \\
\hline $\mathrm{Fe}_{2} \mathrm{O}_{3}$ & 1.00 & 1.04 & 1.11 & 1.04 & 1.13 & 1.00 & 1.10 & 1.09 & 1.09 & 1.07 & 1.09 & 1.12 & 1.13 & 1.10 \\
\hline I & 0.10 & 0.01 & 0.01 & 0.01 & $<0.01$ & 0.10 & 0.01 & $<0.01$ & $<0.01$ & $<0.01$ & 0.01 & $<0.01$ & 0.01 & 0.01 \\
\hline $\mathrm{K}_{2} \mathrm{O}$ & 0.15 & 0.32 & 0.33 & 0.34 & 0.36 & 0.15 & 0.32 & 0.32 & 0.31 & 0.31 & 0.30 & 0.31 & 0.31 & 0.32 \\
\hline $\mathrm{MgO}$ & 1.00 & 0.94 & 0.96 & 1.00 & 1.04 & 1.00 & 0.94 & 0.99 & 0.97 & 0.97 & 1.00 & 0.99 & 0.98 & 0.96 \\
\hline $\mathrm{MnO}$ & $\S$ & 0.01 & 0.01 & 0.01 & 0.01 & $\S$ & 0.01 & 0.01 & 0.01 & 0.01 & 0.01 & 0.01 & 0.01 & 0.01 \\
\hline $\mathrm{Na}_{2} \mathrm{O}$ & 20.00 & 20.90 & 20.04 & 19.73 & 20.29 & 19.96 & 20.24 & 20.56 & 20.09 & 20.47 & 20.93 & 20.30 & 19.98 & 19.98 \\
\hline $\mathrm{NiO}$ & 0.03 & 0.02 & 0.02 & 0.02 & 0.02 & 0.03 & 0.02 & 0.02 & 0.02 & 0.02 & 0.02 & 0.02 & 0.02 & 0.02 \\
\hline $\mathrm{P}_{2} \mathrm{O}_{5}$ & 0.27 & 0.37 & 0.38 & 0.38 & 0.36 & 0.26 & 0.38 & 0.38 & 0.38 & 0.37 & 0.37 & 0.36 & 0.38 & 0.38 \\
\hline $\mathrm{PbO}$ & 0.01 & $<0.01$ & 0.01 & $<0.01$ & 0.01 & 0.01 & $<0.01$ & 0.01 & $<0.01$ & $<0.01$ & 0.01 & $<0.01$ & $<0.01$ & 0.01 \\
\hline $\mathrm{SiO}_{2}$ & 36.62 & 37.51 & 37.64 & 38.29 & 37.56 & 36.54 & 37.58 & 37.21 & 37.60 & 37.56 & 37.01 & 37.07 & 37.33 & 37.99 \\
\hline $\mathrm{SO}_{3}$ & 1.10 & 1.04 & 1.05 & 1.08 & 1.02 & 1.30 & 1.09 & 1.11 & 1.14 & 1.16 & 1.14 & 1.19 & 1.24 & 1.18 \\
\hline $\mathrm{TiO}_{2}$ & $\S$ & 0.21 & 0.22 & 0.21 & 0.21 & $\S$ & 0.22 & 0.22 & 0.22 & 0.21 & 0.21 & 0.22 & 0.22 & 0.21 \\
\hline $\mathrm{V}_{2} \mathrm{O}_{5}$ & 1.00 & 1.06 & 1.11 & 1.07 & 1.09 & 1.00 & 1.09 & 1.08 & 1.08 & 1.06 & 1.08 & 1.11 & 1.11 & 1.05 \\
\hline $\mathrm{ZnO}$ & 3.00 & 2.65 & 2.76 & 2.65 & 2.70 & 2.99 & 2.73 & 2.69 & 2.67 & 2.62 & 2.67 & 2.79 & 2.79 & 2.57 \\
\hline $\mathrm{ZrO} 2$ & 3.00 & 2.72 & 2.85 & 2.74 & 2.86 & 2.99 & 2.92 & 2.97 & 3.10 & 3.03 & 3.04 & 3.25 & 3.19 & 3.05 \\
\hline Sum & 100.00 & 100.00 & 100.00 & 100.00 & 100.00 & 100.00 & 100.00 & 100.00 & 100.00 & 100.00 & 100.00 & 100.00 & 100.00 & 100.00 \\
\hline
\end{tabular}

$\S$ Not a target constituent; * Target value calculated with simple well-stirred tank model; NA - Not Analyzed, NC - Not calculated. 
Table 5.2. XRF Analyzed Composition for DM100 Discharged Glass Samples (wt\%) (continued).

\begin{tabular}{|c|c|c|c|c|c|c|c|c|c|c|c|c|c|c|c|c|}
\hline Test & \multicolumn{16}{|c|}{2} \\
\hline Glass & \multicolumn{16}{|c|}{$1175^{\circ} \mathrm{C}$} \\
\hline & \multirow{2}{*}{\multicolumn{6}{|c|}{1.30}} & & & & & & & & & \multirow{2}{*}{\multicolumn{2}{|c|}{1.15}} \\
\hline Target $\mathrm{SO}_{3}$ & & & & & & & \multicolumn{8}{|c|}{1.23} & & \\
\hline Glass (kg) & \multirow[t]{2}{*}{ Target } & 1038.50 & 1071.10 & 1101.52 & 1130.12 & 1158.46 & Target & 1186.80 & 1211.86 & 1237.04 & 1263.88 & 1293.48 & 1315.14 & 1338.84 & \multirow{2}{*}{ Target } & 1375.54 \\
\hline Constituent & & \begin{tabular}{|c|} 
WVY- \\
G-114A
\end{tabular} & \begin{tabular}{|c|} 
WVY- \\
G-115B
\end{tabular} & \begin{tabular}{|c|} 
WVY- \\
G-116A
\end{tabular} & \begin{tabular}{|c|} 
WVY- \\
G-121A
\end{tabular} & $\begin{array}{l}\text { WVY- } \\
\text { G-121C }\end{array}$ & & \begin{tabular}{|c|} 
WVY- \\
G-124A
\end{tabular} & $\begin{array}{l}\text { WVY- } \\
\text { G-124C }\end{array}$ & $\begin{array}{l}\text { WVY- } \\
\text { G-126B }\end{array}$ & \begin{tabular}{|l|} 
WVY- \\
G-127B
\end{tabular} & $\begin{array}{l}\text { WVY- } \\
\text { G-130A }\end{array}$ & $\begin{array}{l}\text { WVY- } \\
\text { G-130C }\end{array}$ & $\begin{array}{l}\text { WVY- } \\
\text { G-131B }\end{array}$ & & \begin{tabular}{|c|} 
WVY- \\
G-137B
\end{tabular} \\
\hline $\mathrm{Al}_{2} \mathrm{O}_{3}$ & 10.14 & 9.80 & 9.88 & 9.95 & 9.93 & 9.96 & 10.14 & 9.90 & 9.98 & 10.01 & 9.89 & 9.92 & 9.84 & 9.92 & 10.15 & 9.90 \\
\hline $\mathrm{B}_{2} \mathrm{O}_{3} *$ & 13.66 & 13.66 & 13.66 & 13.66 & 13.66 & 13.66 & 13.67 & 13.66 & 13.66 & 13.66 & 13.66 & 13.66 & 13.66 & 13.66 & 13.68 & 13.67 \\
\hline $\mathrm{CaO}$ & 8.00 & 7.23 & 6.99 & 7.06 & 7.26 & 7.02 & 8.01 & 7.24 & 6.98 & 7.18 & 7.14 & 7.32 & 7.26 & 7.05 & 8.01 & 7.13 \\
\hline $\mathrm{Cl}$ & 0.65 & 0.42 & 0.43 & 0.43 & 0.44 & 0.42 & 0.65 & 0.43 & 0.42 & 0.43 & 0.42 & 0.43 & 0.43 & 0.42 & 0.65 & 0.44 \\
\hline $\mathrm{Cr}_{2} \mathrm{O}_{3}$ & 0.02 & 0.14 & 0.13 & 0.13 & 0.12 & 0.12 & 0.02 & 0.13 & 0.19 & 0.13 & 0.13 & 0.14 & 0.13 & 0.13 & 0.02 & 0.13 \\
\hline $\mathrm{F}$ & 0.19 & NA & NA & NA & NA & NA & 0.19 & NA & NA & NA & NA & NA & NA & NA & 0.19 & NA \\
\hline $\mathrm{Fe}_{2} \mathrm{O}_{3}$ & 1.00 & 1.16 & 1.11 & 1.04 & 1.11 & 1.04 & 1.00 & 1.09 & 1.05 & 1.07 & 1.06 & 1.09 & 1.09 & 1.04 & 1.00 & 1.05 \\
\hline I & 0.10 & 0.01 & 0.01 & 0.01 & 0.01 & 0.01 & 0.10 & 0.01 & 0.01 & $<0.01$ & 0.01 & $<0.01$ & 0.01 & 0.01 & 0.10 & 0.01 \\
\hline $\mathrm{K}_{2} \mathrm{O}$ & 0.15 & 0.32 & 0.32 & 0.31 & 0.31 & 0.30 & 0.15 & 0.31 & 0.31 & 0.31 & 0.31 & 0.30 & 0.31 & 0.30 & 0.15 & 0.30 \\
\hline $\mathrm{MgO}$ & 1.00 & 0.93 & 0.89 & 0.96 & 0.87 & 0.90 & 1.00 & 0.90 & 0.87 & 0.88 & 0.87 & 0.85 & 0.86 & 0.95 & 1.00 & 0.93 \\
\hline $\mathrm{MnO}$ & $\S$ & 0.01 & 0.01 & 0.01 & 0.01 & 0.01 & $\S$ & 0.01 & 0.01 & 0.01 & 0.01 & 0.01 & 0.01 & 0.01 & $\S$ & 0.01 \\
\hline $\mathrm{Na}_{2} \mathrm{O}$ & 19.96 & 20.10 & 20.55 & 20.87 & 20.03 & 20.91 & 19.97 & 20.36 & 20.77 & 20.37 & 20.62 & 20.13 & 20.32 & 20.84 & 19.99 & 20.94 \\
\hline $\mathrm{NiO}$ & 0.03 & 0.02 & 0.02 & 0.02 & 0.02 & 0.02 & 0.03 & 0.02 & 0.02 & 0.02 & 0.02 & 0.02 & 0.02 & 0.02 & 0.03 & 0.02 \\
\hline $\mathrm{P}_{2} \mathrm{O}_{5}$ & 0.26 & 0.37 & 0.38 & 0.38 & 0.39 & 0.38 & 0.26 & 0.39 & 0.38 & 0.39 & 0.40 & 0.38 & 0.37 & 0.38 & 0.27 & 0.37 \\
\hline $\mathrm{PbO}$ & 0.01 & 0.01 & $<0.01$ & 0.01 & 0.01 & 0.01 & 0.01 & 0.01 & $<0.01$ & 0.01 & 0.01 & $<0.01$ & 0.01 & $<0.01$ & 0.01 & 0.01 \\
\hline $\mathrm{SiO}_{2}$ & 36.54 & 37.18 & 37.44 & 36.86 & 37.31 & 37.08 & 36.57 & 37.10 & 37.08 & 37.16 & 37.25 & 37.17 & 37.23 & 37.13 & 36.60 & 36.87 \\
\hline $\mathrm{SO}_{3}$ & 1.30 & 1.21 & 1.23 & 1.28 & 1.21 & 1.15 & 1.23 & 1.17 & 1.30 & 1.19 & 1.14 & 1.18 & 1.16 & 1.16 & 1.15 & 1.13 \\
\hline $\mathrm{TiO}_{2}$ & $\S$ & 0.22 & 0.20 & 0.20 & 0.22 & 0.20 & $\S$ & 0.21 & 0.21 & 0.22 & 0.21 & 0.22 & 0.21 & 0.20 & 0.00 & 0.21 \\
\hline $\mathrm{V}_{2} \mathrm{O}_{5}$ & 1.00 & 1.12 & 1.09 & 1.08 & 1.12 & 1.08 & 1.00 & 1.12 & 1.09 & 1.12 & 1.10 & 1.15 & 1.13 & 1.10 & 1.00 & 1.11 \\
\hline $\mathrm{ZnO}$ & 2.99 & 2.78 & 2.62 & 2.66 & 2.78 & 2.67 & 3.00 & 2.77 & 2.66 & 2.74 & 2.71 & 2.82 & 2.79 & 2.68 & 3.00 & 2.73 \\
\hline $\mathrm{ZrO}_{2}$ & 2.99 & 3.29 & 3.06 & 3.09 & 3.19 & 3.05 & 3.00 & 3.15 & 3.01 & 3.09 & 3.05 & 3.19 & 3.14 & 2.99 & 3.00 & 3.02 \\
\hline Sum & 100.00 & 100.00 & 100.00 & 100.00 & 100.00 & 100.00 & 100.00 & 100.00 & 100.00 & 100.00 & 100.00 & 100.00 & 100.00 & 100.00 & 100.00 & 100.00 \\
\hline
\end{tabular}

$\S$ - Not a target constituent; * Target value calculated based on simple well-stirred tank model; NA - Not Analyzed 
Table 5.2. XRF Analyzed Composition for DM100 Discharged Glass Samples (wt\%) (continued).

\begin{tabular}{|c|c|c|c|c|c|c|c|c|c|c|c|c|c|c|c|}
\hline Test & \multicolumn{15}{|c|}{2} \\
\hline Glass & \multicolumn{15}{|c|}{$1175^{\circ} \mathrm{C}$} \\
\hline Target $\mathrm{SO}_{3}$ & \multicolumn{9}{|c|}{1.15} & \multicolumn{6}{|c|}{1.15 (Stoichiometric carbon ratio increased from 0.5 to 0.8 ) } \\
\hline Glass (kg) & \multirow{3}{*}{ Target } & 1400.18 & 1425.74 & 1453.32 & 1479.12 & 1502.42 & 1528.10 & 1541.12 & 1552.90 & 1564.70 & 1575.80 & 1599.98 & 1625.58 & 1654.44 & 1668.08 \\
\hline \multirow{2}{*}{ Constituent } & & WVY-G & WVY-G & WVY-G & WVY-G & WVY-G- & WVY-G- & WVY-G- & WVY-G & WVY-G- & WVY-G & WVY-G- & WVY-G- & WVZ-G- & \multirow{2}{*}{ WVZ-G-5C } \\
\hline & & 138A & $138 \mathrm{C}$ & $140 \mathrm{~A}$ & 141B & 146A & $146 \mathrm{C}$ & $147 \mathrm{~A}$ & 147B & $150 \mathrm{~A}$ & $154 \mathrm{~A}$ & 154C & 155B & 5B & \\
\hline $\mathrm{Al}_{2} \mathrm{O}_{3}$ & 10.15 & 10.00 & 9.96 & 10.05 & 10.06 & 10.02 & 9.96 & 10.02 & 9.88 & 9.98 & 10.08 & 10.04 & 10.02 & 10.06 & 9.93 \\
\hline $\mathrm{B}_{2} \mathrm{O}_{3} *$ & 13.68 & 13.67 & 13.67 & 13.67 & 13.67 & 13.67 & 13.67 & 13.68 & 13.68 & 13.68 & 13.68 & 13.68 & 13.68 & 13.68 & 13.68 \\
\hline $\mathrm{CaO}$ & 8.01 & 7.32 & 7.17 & 7.11 & 7.12 & 7.13 & 7.14 & 7.30 & 7.28 & 7.15 & 6.98 & 7.35 & 7.20 & 7.30 & 7.32 \\
\hline $\mathrm{Cl}$ & 0.65 & 0.43 & 0.43 & 0.33 & 0.43 & 0.41 & 0.41 & 0.42 & 0.42 & 0.42 & 0.41 & 0.42 & 0.43 & 0.44 & 0.44 \\
\hline $\mathrm{Cr}_{2} \mathrm{O}_{3}$ & 0.02 & 0.14 & 0.13 & 0.15 & 0.15 & 0.15 & 0.15 & 0.15 & 0.16 & 0.15 & 0.14 & 0.14 & 0.14 & 0.12 & 0.13 \\
\hline $\mathrm{F}$ & 0.19 & NA & NA & NA & NA & NA & NA & NA & NA & NA & NA & NA & NA & NA & NA \\
\hline $\mathrm{Fe}_{2} \mathrm{O}_{3}$ & 1.00 & 1.09 & 1.05 & 1.03 & 1.03 & 1.05 & 1.02 & 1.06 & 1.07 & 1.04 & 0.98 & 1.06 & 1.07 & 1.06 & 1.04 \\
\hline I & 0.10 & 0.01 & 0.01 & 0.00 & 0.01 & $<0.01$ & 0.01 & 0.01 & 0.01 & 0.01 & 0.02 & 0.03 & 0.03 & 0.04 & 0.04 \\
\hline $\mathrm{K}_{2} \mathrm{O}$ & 0.15 & 0.32 & 0.31 & 0.30 & 0.31 & 0.33 & 0.32 & 0.32 & 0.32 & 0.30 & 0.29 & 0.31 & 0.31 & 0.31 & 0.32 \\
\hline $\mathrm{MgO}$ & 1.00 & 0.91 & 0.90 & 0.98 & 0.89 & 0.90 & 0.92 & 0.93 & 0.92 & 0.97 & 0.92 & 0.85 & 0.93 & 0.90 & 0.89 \\
\hline $\mathrm{MnO}$ & $\S$ & 0.01 & 0.01 & 0.01 & 0.01 & 0.01 & 0.01 & 0.01 & 0.01 & 0.01 & 0.01 & 0.01 & 0.01 & 0.01 & 0.01 \\
\hline $\mathrm{Na}_{2} \mathrm{O}$ & 19.99 & 20.04 & 20.65 & 20.92 & 20.31 & 20.80 & 20.76 & 20.07 & 20.44 & 20.64 & 20.84 & 20.28 & 20.80 & 20.64 & 20.59 \\
\hline $\mathrm{NiO}$ & 0.03 & 0.02 & 0.02 & 0.03 & 0.02 & 0.02 & 0.02 & 0.02 & 0.02 & 0.02 & 0.02 & 0.02 & 0.03 & 0.02 & 0.03 \\
\hline $\mathrm{P}_{2} \mathrm{O}_{5}$ & 0.27 & 0.39 & 0.36 & 0.36 & 0.38 & 0.36 & 0.39 & 0.39 & 0.37 & 0.39 & 0.38 & 0.38 & 0.37 & 0.38 & 0.38 \\
\hline $\mathrm{PbO}$ & 0.01 & 0.01 & 0.01 & 0.01 & 0.01 & $<0.01$ & 0.01 & 0.01 & $<0.01$ & $<0.01$ & $<0.01$ & 0.01 & $<0.01$ & $<0.01$ & 0.01 \\
\hline $\mathrm{SiO}_{2}$ & 36.60 & 37.20 & 37.15 & 36.99 & 37.54 & 37.11 & 37.22 & 37.44 & 37.27 & 37.22 & 37.67 & 37.30 & 37.03 & 37.06 & 37.05 \\
\hline $\mathrm{SO}_{3}$ & 1.15 & 1.16 & 1.12 & 1.10 & 1.17 & 1.11 & 1.10 & 1.09 & 1.10 & 1.08 & 1.09 & 1.07 & 1.05 & 1.02 & 1.05 \\
\hline $\mathrm{TiO}_{2}$ & 0.00 & 0.22 & 0.20 & 0.21 & 0.20 & 0.20 & 0.20 & 0.21 & 0.20 & 0.21 & 0.20 & 0.20 & 0.20 & 0.21 & 0.21 \\
\hline $\mathrm{V}_{2} \mathrm{O}_{5}$ & 1.00 & 1.12 & 1.12 & 1.09 & 1.09 & 1.10 & 1.10 & 1.12 & 1.12 & 1.11 & 1.06 & 1.14 & 1.11 & 1.13 & 1.14 \\
\hline $\mathrm{ZnO}$ & 3.00 & 2.83 & 2.75 & 2.74 & 2.71 & 2.74 & 2.72 & 2.81 & 2.79 & 2.74 & 2.59 & 2.81 & 2.75 & 2.77 & 2.84 \\
\hline $\mathrm{ZrO}_{2}$ & 3.00 & 3.09 & 2.96 & 2.92 & 2.87 & 2.87 & 2.86 & 2.95 & 2.93 & 2.87 & 2.65 & 2.90 & 2.84 & 2.85 & 2.90 \\
\hline Sum & 100.00 & 100.00 & 100.00 & 100.00 & 100.00 & 100.00 & 100.00 & 100.00 & 100.00 & 100.00 & 100.00 & 100.00 & 100.00 & 100.00 & 100.00 \\
\hline
\end{tabular}

$\S$ - Not a target constituent; * Target value calculated based on simple well-stirred tank model; NA - Not Analyzed 
Table 5.2. XRF Analyzed Composition for DM100 Discharged Glass Samples (wt \%) (continued).

\begin{tabular}{|c|c|c|c|c|c|c|c|}
\hline Test & \multicolumn{7}{|c|}{2} \\
\hline Glass & \multicolumn{7}{|c|}{$1175^{\circ} \mathrm{C}$} \\
\hline Target $\mathrm{SO}_{3}$ & \multicolumn{7}{|c|}{$\mathbf{1 . 1 5}$ (Stoichiometric carbon ratio increased from 0.5 to 0.8 ) } \\
\hline Glass (kg) & \multirow{2}{*}{ Target } & 1682.26 & 1695.78 & \begin{tabular}{|r|}
1711.08 \\
\end{tabular} & 1716.56 & \multicolumn{2}{|c|}{$1375-1717$} \\
\hline Constituent & & WVZ-G-10A & WVZ-G-10B & WVZ-G-10C & WVZ-G-11A & Average & \%Dev. \\
\hline $\mathrm{Al}_{2} \mathrm{O}_{3}$ & 10.15 & 10.06 & 9.91 & 11.17 & 10.11 & 10.06 & -0.87 \\
\hline $\mathrm{B}_{2} \mathrm{O}_{3} *$ & 13.68 & 13.68 & 13.68 & 13.68 & 13.68 & 13.67 & $\mathrm{NC}$ \\
\hline $\mathrm{CaO}$ & 8.01 & 7.09 & 7.46 & 7.09 & 7.53 & 7.22 & -9.88 \\
\hline $\mathrm{Cl}$ & 0.65 & 0.44 & 0.45 & 0.43 & 0.44 & 0.42 & $\mathrm{NC}$ \\
\hline $\mathrm{Cr}_{2} \mathrm{O}_{3}$ & 0.02 & 0.11 & 0.12 & 0.11 & 0.13 & 0.14 & $\mathrm{NC}$ \\
\hline $\mathrm{F}$ & 0.19 & NA & NA & NA & NA & NC & $\mathrm{NC}$ \\
\hline $\mathrm{Fe}_{2} \mathrm{O}_{3}$ & 1.00 & 1.00 & 1.05 & 1.01 & 1.08 & 1.05 & 4.43 \\
\hline I & 0.10 & 0.03 & 0.04 & 0.04 & 0.03 & 0.02 & $\mathrm{NC}$ \\
\hline $\mathrm{K}_{2} \mathrm{O}$ & 0.15 & 0.30 & 0.31 & 0.30 & 0.34 & 0.31 & $\mathrm{NC}$ \\
\hline $\mathrm{MgO}$ & 1.00 & 0.91 & 0.92 & 0.93 & 0.87 & 0.91 & -8.86 \\
\hline $\mathrm{MnO}$ & $\S$ & 0.01 & 0.01 & 0.01 & 0.01 & $\mathrm{NC}$ & $\mathrm{NC}$ \\
\hline $\mathrm{Na}_{2} \mathrm{O}$ & 19.99 & 21.22 & 20.21 & 20.07 & 19.13 & 20.49 & 2.52 \\
\hline $\mathrm{NiO}$ & 0.03 & 0.02 & 0.02 & 0.02 & 0.03 & 0.02 & $\mathrm{NC}$ \\
\hline $\mathrm{P}_{2} \mathrm{O}_{5}$ & 0.27 & 0.37 & 0.38 & 0.38 & 0.41 & 0.38 & $\mathrm{NC}$ \\
\hline $\mathrm{PbO}$ & 0.01 & $<0.01$ & $<0.01$ & $<0.01$ & $<0.01$ & $<0.01$ & $\mathrm{NC}$ \\
\hline $\mathrm{SiO}_{2}$ & 36.60 & 37.10 & 37.23 & 37.10 & 38.17 & 37.25 & 1.78 \\
\hline $\mathrm{SO}_{3}$ & 1.15 & 0.97 & 1.01 & 1.00 & 1.06 & 1.08 & -6.29 \\
\hline $\mathrm{TiO}_{2}$ & $\S$ & 0.20 & 0.22 & 0.21 & 0.22 & 0.21 & NC \\
\hline $\mathrm{V}_{2} \mathrm{O}_{5}$ & 1.00 & 1.09 & 1.16 & 1.09 & 1.16 & 1.12 & 11.53 \\
\hline $\mathrm{ZnO}$ & 3.00 & 2.70 & 2.88 & 2.68 & 2.89 & 2.76 & -7.83 \\
\hline $\mathrm{ZrO}_{2}$ & 3.00 & 2.69 & 2.93 & 2.68 & 2.71 & 2.87 & -4.41 \\
\hline Sum & 100.00 & 100.00 & 100.00 & 100.00 & 100.00 & 100.00 & $\mathrm{NC}$ \\
\hline
\end{tabular}

$\S$ - Not a target constituent; * Target value calculated with simple well-stirred tank model; NA - Not Analyzed; NC - Not Calculated 
Table 5.3. Comparison of XRF and DCP Analysis of Melter Glass Samples (wt\%).

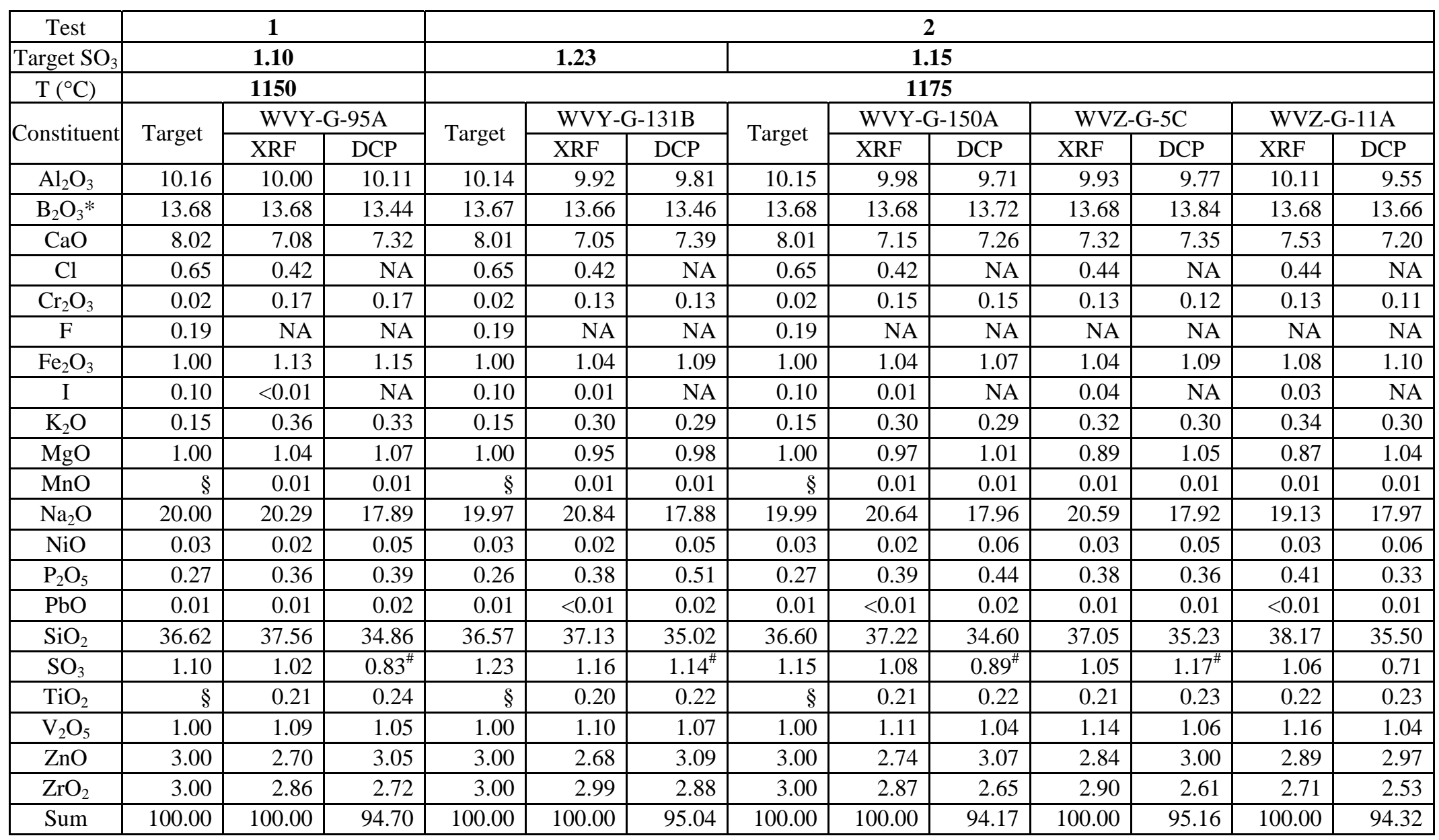

* Target values

\# $\mathrm{SO}_{3}$ measured by IC

$\S$ - Not a target constituent

NA - Not analyzed 
Table 5.4. Dip samples and Presence of Sulfate Layer During DM100 Melter Tests.

\begin{tabular}{|c|c|c|c|c|c|c|c|}
\hline Test & $\begin{array}{c}\text { Glass } \\
\text { Temperature } \\
\left({ }^{\circ} \mathrm{C}\right)\end{array}$ & Date & Time & $\begin{array}{l}\text { Cumulative } \\
\text { Mass (Kg) }\end{array}$ & $\begin{array}{c}\text { Target } \mathrm{SO}_{3} \\
\text { (wt \%) }\end{array}$ & Name & $\begin{array}{c}\text { Secondary } \\
\text { Sulfate Phase }\end{array}$ \\
\hline \multirow{5}{*}{1} & \multirow{5}{*}{1150} & \multirow{2}{*}{$6 / 4 / 05$} & $22: 15$ & 434.50 & \multirow{5}{*}{1.1} & WVY-D-66A & No \\
\hline & & & 22:21 & 464.02 & & WVY-D-70A & No \\
\hline & & \multirow{4}{*}{ 6/6/05 } & \multirow{3}{*}{$12: 15$} & \multirow{3}{*}{807.88} & & WVY-D-95A & No \\
\hline & & & & & & WVY-D-95B & No \\
\hline & & & & & & WVY-D-95C & No \\
\hline \multirow{12}{*}{2} & \multirow{12}{*}{1175} & & 19:23 & 872.48 & \multirow{5}{*}{1.3} & WVY-D-103A & No \\
\hline & & \multirow{4}{*}{ 6/7/05 } & \multirow{2}{*}{$11: 04$} & \multirow{2}{*}{1071.10} & & WVY-D-115A & Yes \\
\hline & & & & & & WVY-D-115B & Yes \\
\hline & & & \multirow{2}{*}{ 19:00 } & \multirow{2}{*}{1186.80} & & WVY-D-122A & Yes \\
\hline & & & & & & WVY-D-122B & Yes \\
\hline & & \multirow{2}{*}{ 6/8/05 } & \multirow{2}{*}{$11: 00$} & \multirow{2}{*}{1293.48} & \multirow{2}{*}{1.23} & WVY-D-130A & Yes \\
\hline & & & & & & WVY-D-130B & Yes \\
\hline & & \multirow{2}{*}{$6 / 9 / 05$} & \multirow{2}{*}{$10: 11$} & \multirow{2}{*}{1541.12} & \multirow{2}{*}{1.15} & WVY-D-147A & No \\
\hline & & & & & & WVY-D-147B & No \\
\hline & & \multirow{3}{*}{$6 / 10 / 05$} & \multirow{3}{*}{ 06:06 } & \multirow{3}{*}{1716.56} & \multirow{3}{*}{$1.15^{*}$} & WVZ-D-11A & No \\
\hline & & & & & & WVZ-D-11B & No \\
\hline & & & & & & WVZ-D-11C & No \\
\hline
\end{tabular}

* Stoichiometric carbon ratio increased from 0.5 to 0.8

Table 5.5. Glass Redox for Selected Glass Samples.

\begin{tabular}{|c|c|c|c|c|c|c|}
\hline Test & $\begin{array}{c}\text { Glass } \\
\text { Temperature } \\
\left({ }^{\circ} \mathbf{C}\right)\end{array}$ & $\begin{array}{c}\text { Stoichiometric } \\
\text { carbon ratio }\end{array}$ & Date & Sample I.D. & $\begin{array}{c}\text { Cumulative } \\
\text { Glass (kg) }\end{array}$ & $\begin{array}{c}\mathbf{\% F e}^{2+} \\
/ \text { Total Fe }\end{array}$ \\
\hline 1 & 1150 & 0.5 & $6 / 6 / 05$ & WVY-95A & 807.88 & $<4.0$ \\
\hline 2 & 1175 & 0.5 & $6 / 9 / 05$ & WVY-150A & 1564.70 & $<4.0$ \\
\cline { 3 - 6 } 2 & 0.8 & $6 / 10 / 05$ & WVZ-G-11A & 1716.56 & 30.5 \\
\hline
\end{tabular}


The Catholic University of America Vitreous State Laboratory
LAW Envelope C Glass Formulation Testing to Increase Waste Loading Final Report, VSL-05R5900-1, Rev. 0

Table 5.6. Results of PCT (ASTM C1285, 7-days at $90^{\circ} \mathrm{C}$ ) and VHT (at $200^{\circ} \mathrm{C}$ for 24 Days (g/ $\mathrm{m}^{2} /$ day)) for LAW Envelope C Crucible and DM100 Melter Glasses.

\begin{tabular}{|c|c|c|c|c|}
\hline Glass Sample & $\begin{array}{l}\text { LAWC100 } \\
\text { Crucible melt }\end{array}$ & $\begin{array}{l}\text { LAWC100R1* } \\
\text { Crucible melt }\end{array}$ & $\begin{array}{l}\text { WVY-G-95A } \\
\text { Melter Glass }\end{array}$ & $\begin{array}{c}\text { WTP } \\
\text { Contract } \\
\text { Limit } \\
\end{array}$ \\
\hline \multicolumn{5}{|c|}{ 7-Day PCT, Stainless Steel Vessel; S/V=2000m $\mathrm{m}^{-1}$} \\
\hline \multicolumn{5}{|l|}{ Concentration in ppm } \\
\hline $\mathrm{B}$ & 44.44 & 71.49 & 78.24 & - \\
\hline $\mathrm{Na}$ & 128.60 & 224.3 & 232.00 & - \\
\hline Si & 33.49 & 51.12 & 48.10 & - \\
\hline \multicolumn{5}{|l|}{ 7-Day PCT Normalized Concentrations (g/L) } \\
\hline $\mathrm{B}$ & 1.05 & 1.68 & 1.84 & - \\
\hline $\mathrm{Na}$ & 0.87 & 1.51 & 1.56 & - \\
\hline $\mathrm{Si}$ & 0.20 & 0.30 & 0.28 & - \\
\hline $\mathrm{pH}$ & 10.61 & 11.06 & 11.12 & - \\
\hline \multicolumn{5}{|l|}{ 7-Day PCT Normalized Mass Loss (g/m²) } \\
\hline $\mathrm{B}$ & 0.52 & 0.84 & 0.92 & $<2.0$ \\
\hline $\mathrm{Na}$ & 0.43 & 0.76 & 0.78 & $<2.0$ \\
\hline Si & 0.10 & 0.15 & 0.14 & $<2.0$ \\
\hline \multicolumn{5}{|l|}{ 7-Day PCT Normalized Loss Rate (g/m²/d) } \\
\hline $\mathrm{B}$ & 0.07 & 0.12 & 0.13 & - \\
\hline $\mathrm{Na}$ & 0.06 & 0.11 & 0.11 & - \\
\hline Si & 0.01 & 0.02 & 0.02 & - \\
\hline \multicolumn{5}{|l|}{ VHT Alteration (24 days at $200^{\circ} \mathrm{C}$ ) } \\
\hline Duration (days) & 24 & 24 & 24 & - \\
\hline Alteration depth $(\mu \mathrm{m})$ & 95 & 144 & 102 & - \\
\hline $\begin{array}{l}\text { Alteration Rate }\left(\mathrm{g} / \mathrm{m}^{2} / \mathrm{d}\right) \text { calculated using } \\
\text { measured density of } 2.600 \mathrm{~g} / \mathrm{cc}\end{array}$ & 10.3 & 15.6 & 11.1 & $<50.0$ \\
\hline
\end{tabular}

* LAWC100R1 is a remelt of LAWC100 
The Catholic University of America Vitreous State Laboratory
LAW Envelope C Glass Formulation Testing

to Increase Waste Loading

Final Report, VSL-05R5900-1, Rev. 0

Table 6.1. Results from Melter Off-Gas Emission Samples.

\begin{tabular}{|c|c|c|c|c|c|c|c|c|c|}
\hline & \multicolumn{4}{|c|}{ Test 1} & \multicolumn{4}{|c|}{ Test 2} \\
\hline & & \multicolumn{4}{|c|}{$\begin{array}{c}\text { 06/05/05 11:12 - 12:12 } \\
97.2 \% \text { Isokinetic, } 12.3 \% \text { Moisture }\end{array}$} & \multicolumn{4}{|c|}{$\begin{array}{c}\text { 06/09/05 13:54 - 14:54 } \\
94.5 \% \text { Isokinetic, } 13.1 \% \text { Moisture }\end{array}$} \\
\hline & & $\begin{array}{l}\text { Feed Rate } \\
\text { (mg/min) }\end{array}$ & $\begin{array}{c}\text { Emissions } \\
\text { Rate } \\
\text { (mg/min) }\end{array}$ & $\%$ of Feed & DF & $\begin{array}{l}\text { Feed Rate } \\
\text { (mg/min) }\end{array}$ & $\begin{array}{c}\text { Emissions } \\
\text { Rate } \\
\text { (mg/min) }\end{array}$ & $\begin{array}{l}\% \text { of } \\
\text { Feed }\end{array}$ & DF \\
\hline \multirow{20}{*}{ 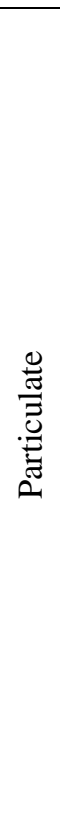 } & Total $^{\$}$ & 199800 & 1196 & 0.60 & 167 & 199800 & 1249 & 0.63 & 160 \\
\hline & $\mathrm{Al}$ & 9070 & 2.46 & $<0.10$ & 3682 & 9070 & 2.06 & $<0.10$ & 4399 \\
\hline & B & 7164 & 16.37 & 0.23 & 438 & 7164 & 21.17 & 0.30 & 338 \\
\hline & $\mathrm{Ca}$ & 9674 & 2.79 & $<0.10$ & 3464 & 9674 & 1.80 & $<0.10$ & 5361 \\
\hline & $\mathrm{Cl}^{*}$ & 1097 & 521 & 47.5 & 2.1 & 1097 & 551 & 50.2 & 2.0 \\
\hline & $\mathrm{Cr}$ & 23 & 2.68 & 11.60 & 8.6 & 23 & 1.59 & 6.90 & 14.5 \\
\hline & $\mathrm{F}^{*}$ & 321 & 30 & 9.35 & 10.7 & 321 & 13 & 4.05 & 24.7 \\
\hline & $\mathrm{Fe}$ & 1180 & 0.69 & $<0.10$ & 1704 & 1180 & 0.67 & $<0.10$ & 1773 \\
\hline & $\mathrm{I}^{*}$ & 169 & 4.96 & 2.93 & 34.1 & 169 & $<0.10$ & $<0.10$ & $>1690$ \\
\hline & $\mathrm{K}$ & 210 & 24.78 & 11.79 & 8.5 & 210 & 21.25 & 10.11 & 9.9 \\
\hline & $\mathrm{Mg}$ & 1018 & 0.11 & $<0.10$ & 9467 & 1018 & $<0.10$ & $<0.01$ & $>10180$ \\
\hline & $\mathrm{Na}$ & 25040 & 338.75 & 1.35 & 73.9 & 25040 & 340.97 & 1.36 & 73.4 \\
\hline & $\mathrm{Ni}$ & 40 & $<0.10$ & $<0.25$ & $>400$ & 40 & $<0.10$ & $<0.25$ & $>400$ \\
\hline & $\mathrm{P}$ & 199 & 0.26 & 0.13 & 769 & 199 & $<0.10$ & $<0.10$ & $>1990$ \\
\hline & $\mathrm{Pb}$ & 16 & $<0.10$ & $<0.63$ & $>160$ & 16 & 0.12 & 0.79 & 126 \\
\hline & $\mathrm{S}$ & 812 & 29.85 & 4.01 & 24.9 & 778 & 48.48 & 6.23 & 16.0 \\
\hline & $\mathrm{Si}$ & 28888 & 4.69 & $<0.10$ & 6159 & 28888 & 3.46 & $<0.10$ & 8342 \\
\hline & $\mathrm{V}$ & 473 & 2.55 & 0.54 & 185 & 473 & 1.47 & 0.31 & 322 \\
\hline & $\mathrm{Zn}$ & 4067 & 4.04 & 0.10 & 1008 & 4067 & 4.67 & 0.11 & 872 \\
\hline & $\mathrm{Zr}$ & 3748 & 0.18 & $<0.10$ & 20320 & 3748 & 0.17 & $<0.10$ & 22000 \\
\hline \multirow{5}{*}{ రే } & B & 7164 & 28.64 & 0.40 & 250 & 7164 & 54.84 & 0.77 & 131 \\
\hline & $\mathrm{Cl}$ & 1097 & 3.74 & 0.34 & 293 & 1097 & 26.31 & 2.40 & 41.7 \\
\hline & $\mathrm{F}$ & 321 & 36.33 & 11.33 & 8.8 & 321 & 57.40 & 17.90 & 5.6 \\
\hline & I & 169 & 97.98 & 58.06 & 1.7 & 169 & 52.65 & 31.20 & 3.2 \\
\hline & $\mathrm{S}$ & 812 & 1.18 & 0.16 & 631 & 778 & 40.67 & 5.23 & 19.1 \\
\hline
\end{tabular}

$\$$ - From gravimetric analysis of filters and front-half nitric acid analytical results

* - From water dissolution of filter particulate

- Empty data field 
The Catholic University of America Vitreous State Laboratory
LAW Envelope C Glass Formulation Testing to Increase Waste Loading Final Report, VSL-05R5900-1, Rev. 0

Table 6.2. Average Concentration (ppmv) of Selected Species in Off-Gas Measured by FTIR Spectroscopy during DM100 Tests.

\begin{tabular}{|c|c|c|c|c|}
\hline & Test 1 & Test 2c & Test 2d & Test 2e \\
\hline Glass Temperature & \multicolumn{4}{|c|}{$1175^{\circ} \mathrm{C}$} \\
\hline Feed Sugar Ratio & \multicolumn{3}{|c|}{0.5 including waste organics } & $\begin{array}{c}0.8 \\
\text { (0.5 excluding waste } \\
\text { organics) }\end{array}$ \\
\hline $\mathrm{N}_{2} \mathrm{O}$ & 115 & 128 & 130 & 157 \\
\hline NO & 1437 & 1623 & 1666 & 1071 \\
\hline $\mathrm{NO}_{2}$ & 233 & 258 & 277 & 75 \\
\hline $\mathrm{NH}_{3}$ & 67 & 80 & 77 & 178 \\
\hline $\mathrm{H}_{2} \mathrm{O}[\%]$ & 5.7 & 6.5 & 6.4 & 6.8 \\
\hline $\mathrm{CO}_{2}$ & 3000 & 3000 & 3000 & 4000 \\
\hline $\mathrm{HNO}_{2}$ & 1.1 & 1.1 & 1.1 & $<1.0$ \\
\hline $\mathrm{HNO}_{3}$ & $<1.0$ & $<1.0$ & $<1.0$ & $<1.0$ \\
\hline $\mathrm{HCN}$ & $<1.0$ & $<1.0$ & $<1.0$ & 2.6 \\
\hline $\mathrm{SO}_{2}$ & $<1.0$ & 1.3 & $<1.0$ & 2.2 \\
\hline Acetonitrile & $<1.0$ & $<1.0$ & $<1.0$ & 7.4 \\
\hline Acrylonitrile & $<1.0$ & $<1.0$ & $<1.0$ & $<1.0$ \\
\hline $\mathrm{CO}$ & 80 & 93 & 96 & 161 \\
\hline $\mathrm{HCl}$ & $<1.0$ & $<1.0$ & $<1.0$ & $<1.0$ \\
\hline HF & $<1.0$ & $<1.0$ & $<1.0$ & $<1.0$ \\
\hline
\end{tabular}


The Catholic University of America Vitreous State Laboratory
LAW Envelope C Glass Formulation Testing to Increase Waste Loading Final Report, VSL-05R5900-1, Rev. 0

Table 6.3. Concentration Ranges (ppmv) of Selected Species in Off-Gas Measured by FTIR Spectroscopy during DM100 Tests.

\begin{tabular}{|c|c|c|c|c|}
\hline & Test 1 & Test 2c & Test 2d & Test 2e \\
\hline Glass Temperature & $1150^{\circ} \mathrm{C}$ & \multicolumn{3}{|c|}{$1175^{\circ} \mathrm{C}$} \\
\hline Feed Sugar Ratio & \multicolumn{3}{|c|}{0.5 including waste organics } & $\begin{array}{c}0.8 \\
(0.5 \text { excluding waste } \\
\text { organics })\end{array}$ \\
\hline $\mathrm{N}_{2} \mathrm{O}$ & $<1.0-264$ & $<1.0-310$ & $<1.0-208$ & $<1.0-308$ \\
\hline $\mathrm{NO}$ & $<1.0-2990$ & $6.6-3366$ & $13.8-2484$ & $13.2-2278$ \\
\hline $\mathrm{NO}_{2}$ & $<1.0-658$ & $1.3-738$ & $5.4-503$ & $2.7-235$ \\
\hline $\mathrm{NH}_{3}$ & $<1.0-226$ & $2.5-309$ & $6.1-178$ & $8.8-311$ \\
\hline $\mathrm{H}_{2} \mathrm{O}[\%]$ & $1.0-12$ & $1.4-12$ & $1.6-13$ & $2.3-12$ \\
\hline $\mathrm{CO}_{2}$ & $<1.0-22000$ & $<1.0-6000$ & $<1.0-6000$ & $<1.0-8000$ \\
\hline $\mathrm{HNO}_{2}$ & $<1.0-3.4$ & $<1.0-3.7$ & $<1.0-2.2$ & $<1.0-1.2$ \\
\hline $\mathrm{HNO}_{3}$ & $<1.0$ & $<1.0$ & $<1.0$ & $<1.0$ \\
\hline $\mathrm{HCN}$ & $<1.0-1.4$ & $<1.0-1.4$ & $<1.0-2.0$ & $<1.0-4.7$ \\
\hline $\mathrm{SO}_{2}$ & $<1.0$ & $<1.0-4.4$ & $<1.0$ & $<1.0-7.4$ \\
\hline Acetonitrile & $<1.0$ & $<1.0$ & $<1.0$ & $<1.0-33$ \\
\hline Acrylonitrile & $<1.0$ & $<1.0$ & $<1.0$ & $<1.0$ \\
\hline $\mathrm{CO}$ & $<1.0-192$ & $<1.0-215$ & $<1.0-153$ & $<1.0-295$ \\
\hline $\mathrm{HCl}$ & $<1.0$ & $<1.0$ & $<1.0$ & $<1.0-1.0$ \\
\hline $\mathrm{HF}$ & $<1.0-11$ & $<1.0$ & $<1.0-10$ & $<1.0-1.0$ \\
\hline
\end{tabular}


The Catholic University of America Vitreous State Laboratory
LAW Envelope C Glass Formulation Testing to Increase Waste Loading Final Report, VSL-05R5900-1, Rev. 0

Table 6.4. Average NOx Fluxes in Off-Gas Measured by FTIR Spectroscopy.

\begin{tabular}{|c|c|c|c|c|c|}
\hline \multirow{2}{*}{ Test } & \multirow{2}{*}{$\begin{array}{c}\text { Feed } \\
{[\mathbf{m o l} / \mathbf{h r}]}\end{array}$} & \multicolumn{3}{|c|}{ Emissions [mol/h] } & \multirow{2}{*}{ \% Feed NO $\mathbf{x}_{\mathbf{x}}$ Emitted as Nitrogen Oxides } \\
\cline { 3 - 6 } & & $\mathbf{N}_{\mathbf{2}} \mathbf{O}[\mathbf{m o l} / \mathbf{h r}]$ & $\mathbf{N O}[\mathbf{m o l} / \mathbf{h r}]$ & $\mathbf{N O}_{2}[\mathbf{m o l} / \mathbf{h r}]$ & \\
\hline 1 & 34.7 & 1.3 & 15.6 & 2.5 & 55.7 \\
\hline 2c & 36.1 & 1.4 & 17.5 & 2.8 & 59.9 \\
\hline 2d & 35.2 & 1.4 & 17.9 & 3.0 & 63.5 \\
\hline 2e & 36.3 & 1.6 & 11.1 & 0.8 & 37.1 \\
\hline
\end{tabular}


Table 6.5. Mass Balances for Sulfur, Iodine, and Chlorine During DM100 Tests with LAW High-Sodium Simulants (\% of Feed).

\begin{tabular}{|c|c|c|c|c|c|c|}
\hline Test & $\begin{array}{c}\text { Stoichiometric } \\
\text { Ratio } \\
\end{array}$ & Element & Glass & $\begin{array}{c}\text { Particle } \\
\text { Emissions } \\
\end{array}$ & $\begin{array}{c}\text { Gaseous } \\
\text { Emissions } \\
\end{array}$ & Total \\
\hline \multirow{3}{*}{$\begin{array}{c}\text { Thiswork @ } \\
1150^{\circ} \mathrm{C} \\
\left(\mathrm{SO}_{3}=1.1 \mathrm{wt} \%\right)\end{array}$} & \multirow{3}{*}{$\begin{array}{c}0.5 \text { Sugar + } \\
\text { Waste } \\
\text { Organics }\end{array}$} & Chlorine & 66 & 48 & 0.3 & 114 \\
\hline & & Sulfur & 95 & 4.0 & 0.2 & 99 \\
\hline & & Iodine & 10 & 2.9 & 58 & 71 \\
\hline \multirow{3}{*}{$\begin{array}{c}\text { This work @ } \\
1175^{\circ} \mathrm{C} \\
\left(\mathrm{SO}_{3}=1.15 \mathrm{wt} \%\right)\end{array}$} & \multirow{3}{*}{$\begin{array}{l}0.8 \text { Sugar + } \\
\text { Waste } \\
\text { Organics }\end{array}$} & Chlorine & 65 & 50 & 2.4 & 117 \\
\hline & & Sulfur & 87 & 6.2 & 5.2 & 98 \\
\hline & & Iodine & 40 & $<0.1$ & 31 & 71 \\
\hline \multirow{2}{*}{$\begin{array}{c}\text { LAWA161 }\left(\mathrm{SO}_{3}=\right. \\
1.0 \mathrm{wt} \%)[2]\end{array}$} & \multirow{2}{*}{0.5 Sugar } & Chlorine & 48 & 41 & 0.4 & 89 \\
\hline & & Sulfur & 84 & 6.4 & 0.2 & 91 \\
\hline \multirow{2}{*}{$\begin{array}{c}\text { LAWA161 }\left(\mathrm{SO}_{3}=\right. \\
1.25 \mathrm{wt} \%)[2]\end{array}$} & \multirow{2}{*}{0.5 Sugar } & Chlorine & 52 & 57 & 0.3 & 109 \\
\hline & & Sulfur & 90 & 9.6 & 0.2 & 100 \\
\hline \multirow{2}{*}{$\begin{array}{c}\text { Urea and Sugar } \\
\left(\mathrm{SO}_{3}=0.5 \mathrm{wt} \%\right) \\
{[4]}\end{array}$} & \multirow{2}{*}{$\begin{array}{r}0.5 \text { Urea }+ \\
0.5 \text { Sugar }\end{array}$} & Chlorine & 51 & 42 & $<0.1$ & 93 \\
\hline & & Sulfur & 66 & 16 & 7.55 & 90 \\
\hline \multirow{2}{*}{$\begin{array}{c}\text { Vanadium } \\
\text { Additive }\left(\mathrm{SO}_{3}=\right. \\
0.5 \mathrm{wt} \%)[4]\end{array}$} & \multirow{2}{*}{0.5 Sugar } & Chlorine & 47 & 55 & $<0.1$ & 102 \\
\hline & & Sulfur & 78 & 14 & 0.4 & 92 \\
\hline \multirow{3}{*}{$\begin{array}{c}\text { Starch and Sugar } \\
\left(\mathrm{SO}_{3}=0.5 \mathrm{wt} \%\right) \\
{[3]}\end{array}$} & \multirow{3}{*}{$\begin{array}{c}0.5 \text { Starch }+ \\
0.25 \text { Sugar }\end{array}$} & Chlorine & 50 & 47 & $<0.1$ & 97 \\
\hline & & Sulfur & 70 & 30 & 13.6 & 114 \\
\hline & & Iodine & 40 & 17 & 27 & 84 \\
\hline \multirow{2}{*}{$\begin{array}{c}\text { @ } 1175^{\circ} \mathrm{C} \\
\left(\mathrm{SO}_{3}=0.23 \mathrm{wt} \%\right) \\
{[3]}\end{array}$} & \multirow{2}{*}{0.5 Sugar } & Chlorine & 75 & 42 & $<0.1$ & 117 \\
\hline & & Sulfur & 91 & 9.2 & 0.4 & 101 \\
\hline \multirow{2}{*}{$\begin{array}{c}@ 1225^{\circ} \mathrm{C} \\
\left(\mathrm{SO}_{3}=0.23 \mathrm{wt} \%\right) \\
{[3]}\end{array}$} & \multirow{2}{*}{0.5 Sugar } & Chlorine & 66 & 61 & $<0.1$ & 127 \\
\hline & & Sulfur & 81 & 19 & 0.6 & 100 \\
\hline
\end{tabular}

"-" Empty data field 
Table 7.1. Compositions and Properties of "New” and “Old” LAW C Glasses for AN-102

\begin{tabular}{|c|c|c|c|c|}
\hline \multicolumn{2}{|c|}{ Glass Formulation - Sample ID } & LAWC35 (Old) & LAWC31 (Old) & LAWC100 (New) \\
\hline \multicolumn{2}{|c|}{ Waste Composition } & AN-102 & AN-102 & AN-102 \\
\hline \multicolumn{2}{|c|}{ Oxide Loading } & $13.95 \mathrm{wt} \%$ & $13.73 \mathrm{wt} \%$ & $24.06 \mathrm{wt} \%$ \\
\hline \multirow{23}{*}{$\begin{array}{c}\text { Target Glass } \\
\text { Compositions for } \\
\text { Melter Glasses (wt\%) }\end{array}$} & $\mathrm{Al}_{2} \mathrm{O}_{3}$ & 6.06 & 6.10 & 10.16 \\
\hline & $\mathrm{B}_{2} \mathrm{O}_{3}$ & 9.41 & 10.02 & 13.68 \\
\hline & $\mathrm{CaO}$ & 7.34 & 7.39 & 8.02 \\
\hline & $\mathrm{Cr}_{2} \mathrm{O}_{3}$ & 0.01 & 0.02 & 0.02 \\
\hline & $\mathrm{Cs}_{2} \mathrm{O}$ & 0.15 & 0.15 & - \\
\hline & $\mathrm{Fe}_{2} \mathrm{O}_{3}$ & 3.59 & 4.42 & 1.00 \\
\hline & $\mathrm{K}_{2} \mathrm{O}$ & 0.09 & 0.14 & 0.15 \\
\hline & $\mathrm{Li}_{2} \mathrm{O}$ & 3.25 & 2.73 & - \\
\hline & $\mathrm{MgO}$ & 1.49 & 1.50 & 1.00 \\
\hline & $\mathrm{Na}_{2} \mathrm{O}$ & 11.96 & 11.93 & 20.00 \\
\hline & $\mathrm{NiO}$ & - & 0.01 & 0.03 \\
\hline & $\mathrm{PbO}$ & 0.01 & - & 0.01 \\
\hline & $\mathrm{SiO}_{2}$ & 47.19 & 46.63 & 36.62 \\
\hline & $\mathrm{V}_{2} \mathrm{O}_{5}$ & - & - & 1.00 \\
\hline & $\mathrm{TiO}_{2}$ & 1.08 & 1.12 & - \\
\hline & $\mathrm{ZnO}$ & 3.98 & 4.01 & 3.00 \\
\hline & $\mathrm{ZrO}_{2}$ & 2.99 & 3.01 & 3.00 \\
\hline & $\mathrm{Cl}$ & 0.39 & 0.11 & 0.65 \\
\hline & $\mathrm{F}$ & 0.11 & 0.05 & 0.19 \\
\hline & I & 0.10 & 0.10 & 0.10 \\
\hline & $\mathrm{P}_{2} \mathrm{O}_{5}$ & 0.16 & 0.10 & 0.27 \\
\hline & $\mathrm{SO}_{3}$ & 0.63 & 0.47 & 1.10 \\
\hline & SUM & 100.0 & 100.0 & 100.0 \\
\hline \multicolumn{2}{|c|}{$\mathrm{SO}_{3}$ Measured in DM100 Melter Glass } & 0.50 & 0.43 & 1.05 \\
\hline \multicolumn{2}{|c|}{$\mathrm{SO}_{3}$ Retention in DM100 Melter Glass } & $79 \%$ & $91 \%$ & $95 \%$ \\
\hline \multirow{3}{*}{ Viscosity $(\mathrm{P})^{*}$} & at $1100^{\circ} \mathrm{C}$ & 55 & 117 & 52 \\
\hline & at $1150^{\circ} \mathrm{C}$ & 35 & 67 & 32 \\
\hline & at $1200^{\circ} \mathrm{C}$ & 23 & 41 & 21 \\
\hline \multirow{3}{*}{$\begin{array}{l}\text { Electrical Conductivity } \\
\qquad(\mathrm{S} / \mathrm{cm})^{*}\end{array}$} & at $1100^{\circ} \mathrm{C}$ & 0.21 & 0.22 & 0.24 \\
\hline & at $1150^{\circ} \mathrm{C}$ & 0.27 & 0.28 & 0.29 \\
\hline & at $1200^{\circ} \mathrm{C}$ & 0.32 & 0.35 & 0.35 \\
\hline \multirow{3}{*}{$\operatorname{PCT}\left(\mathrm{g} / \mathrm{m}^{2}\right)^{*}$} & $\mathrm{~B}$ & 0.34 & 0.28 & 0.52 \\
\hline & $\mathrm{Na}$ & 0.38 & 0.31 & 0.43 \\
\hline & $\mathrm{Si}$ & 0.15 & 0.12 & 0.10 \\
\hline VHT (g/m²/day)* & 24 day rate & 17 & 12 & 10 \\
\hline \multirow{3}{*}{$\begin{array}{l}\text { Glass Production Rate } \\
\left(\mathrm{kg} / \mathrm{m}^{2} / \text { day }\right)\end{array}$} & DM100-1150 ${ }^{\circ} \mathrm{C}$ & $2000[18]$ & $2030[15]$ & 2250 \\
\hline & DM100-1175C & - & - & 3300 \\
\hline & LAW Pilot $-1150^{\circ} \mathrm{C}$ & $2100[26]$ & $2210[30]$ & - \\
\hline Bubbling (lpm) & DM100 & 11.6 & 19.3 & 17.1 \\
\hline
\end{tabular}

* Viscosity, electrical conductivity, PCT and VHT were measured on crucible glasses whose compositions are close to, but very slightly different from, the melter glasses. Crucible glasses do not contain I, and their $\mathrm{SO}_{3}$ contents are different from the melter glasses.

- Empty data field 
The Catholic University of America Vitreous State Laboratory
LAW Envelope C Glass Formulation Testing

to Increase Waste Loading

Final Report, VSL-05R5900-1, Rev. 0

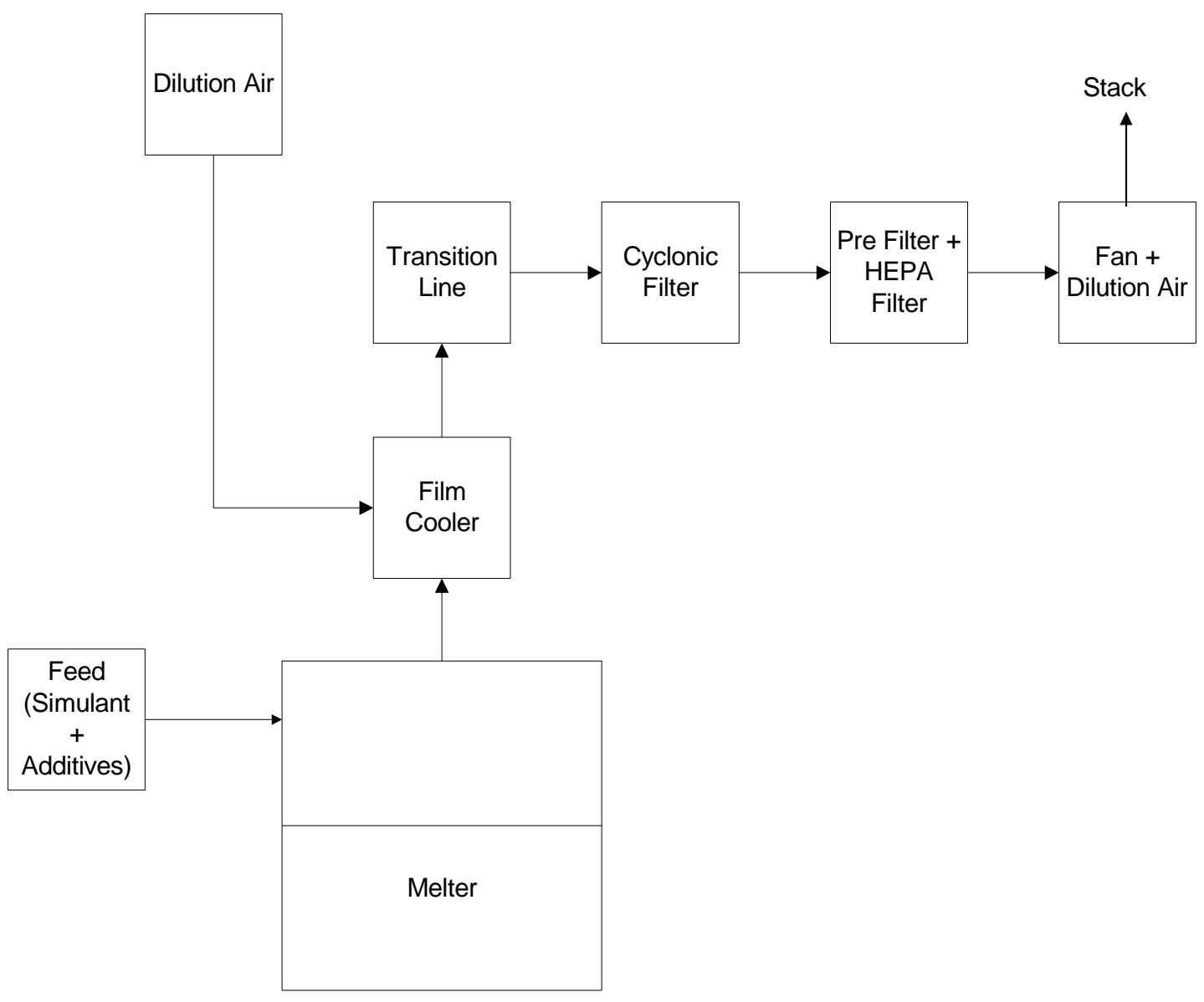

Figure 1.1. Schematic diagram of DuraMelter 100-WV vitrification system. 
The Catholic University of America Vitreous State Laboratory
LAW Envelope C Glass Formulation Testing

to Increase Waste Loading

Final Report, VSL-05R5900-1, Rev. 0

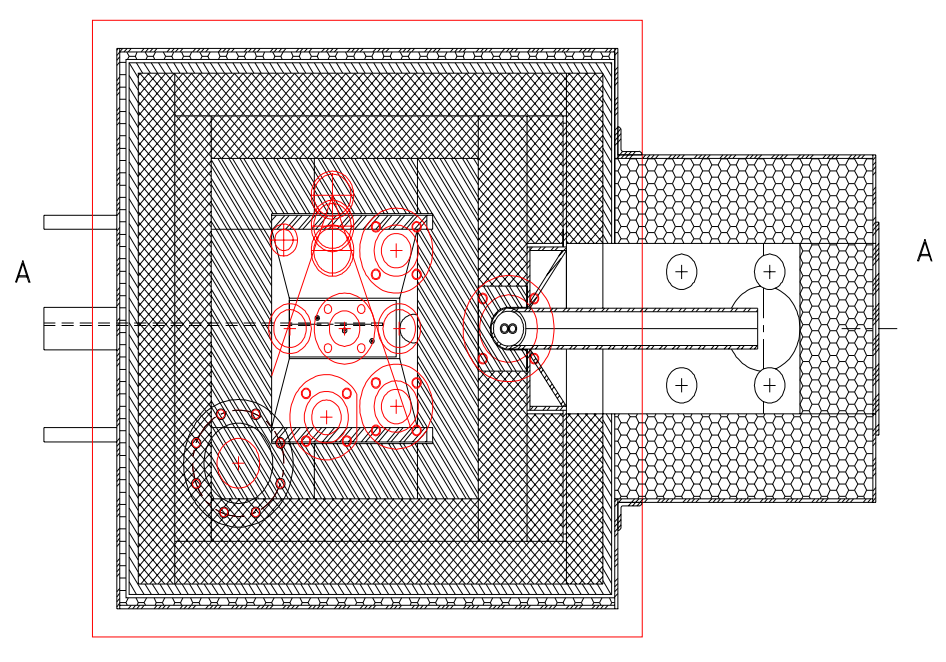

SECTION B-B

(BACKCROUND OMITED)

Figure 1.2(a). Cross-section through the DM100-WV melter-Plan View. 
The Catholic University of America Vitreous State Laboratory
LAW Envelope C Glass Formulation Testing

to Increase Waste Loading

Final Report, VSL-05R5900-1, Rev. 0

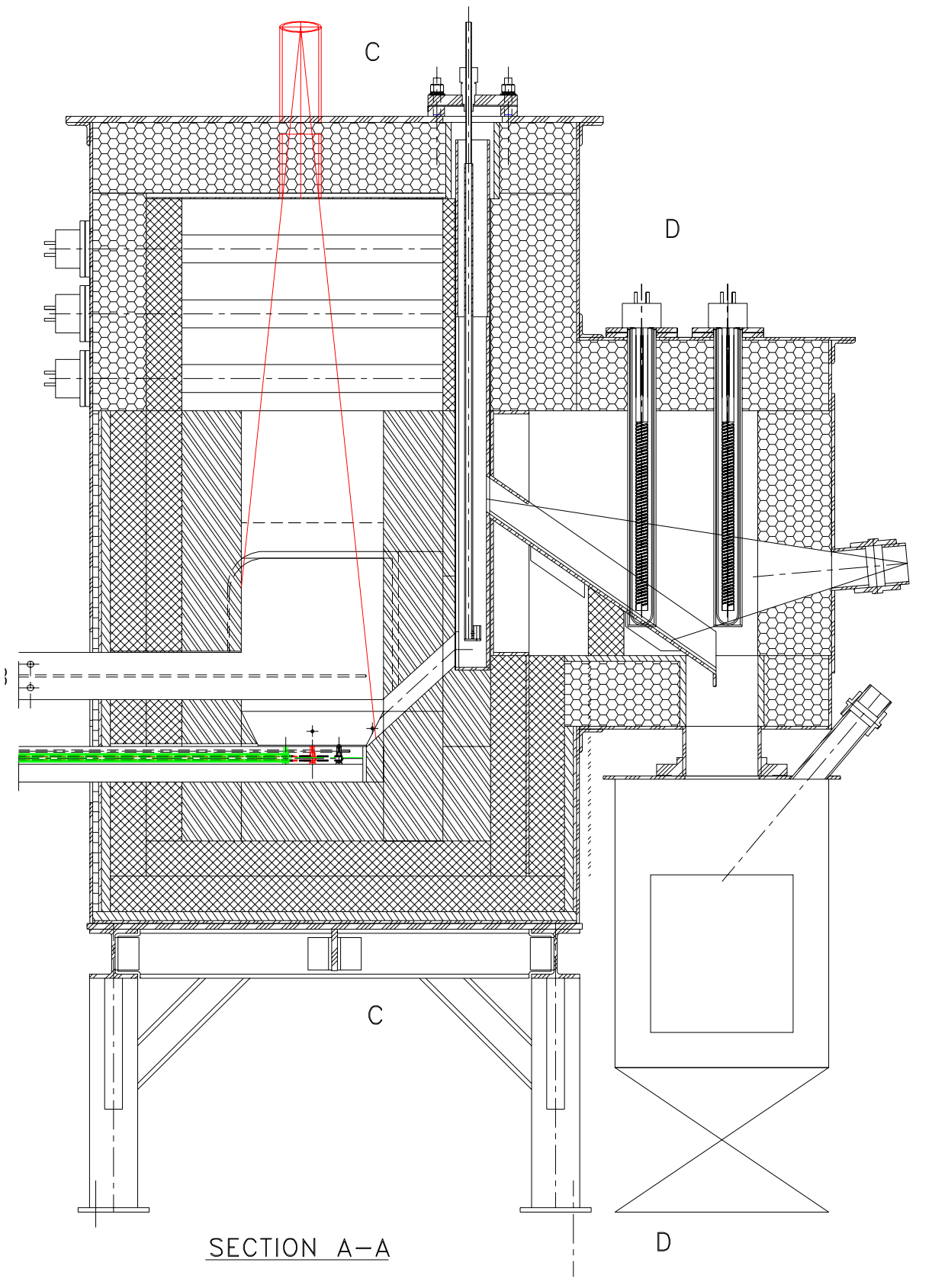

Figure 1.2(b). Cross-section through the DM100-WV melter-Section AA. 
The Catholic University of America Vitreous State Laboratory
LAW Envelope C Glass Formulation Testing

to Increase Waste Loading

Final Report, VSL-05R5900-1, Rev. 0

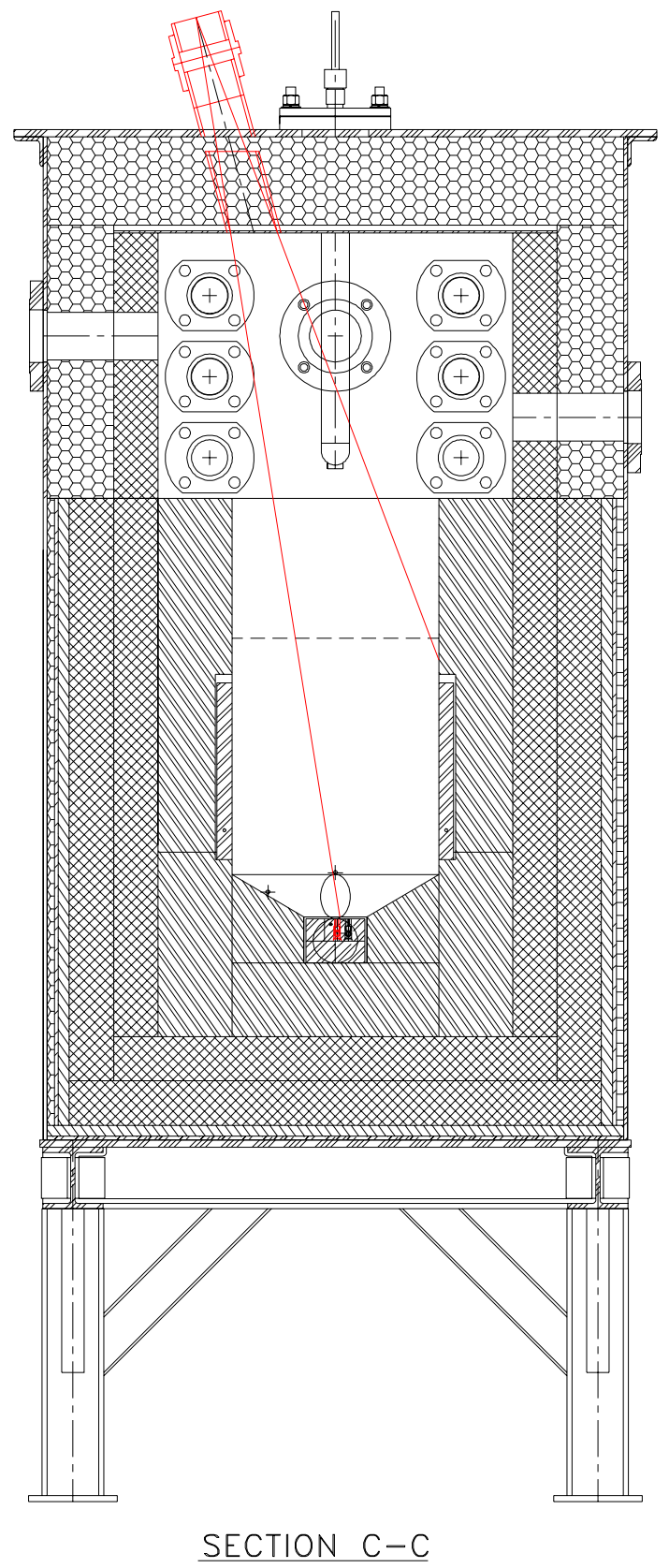

Figure 1.2(c). Cross-section through the DM100-WV melter-Section CC. 


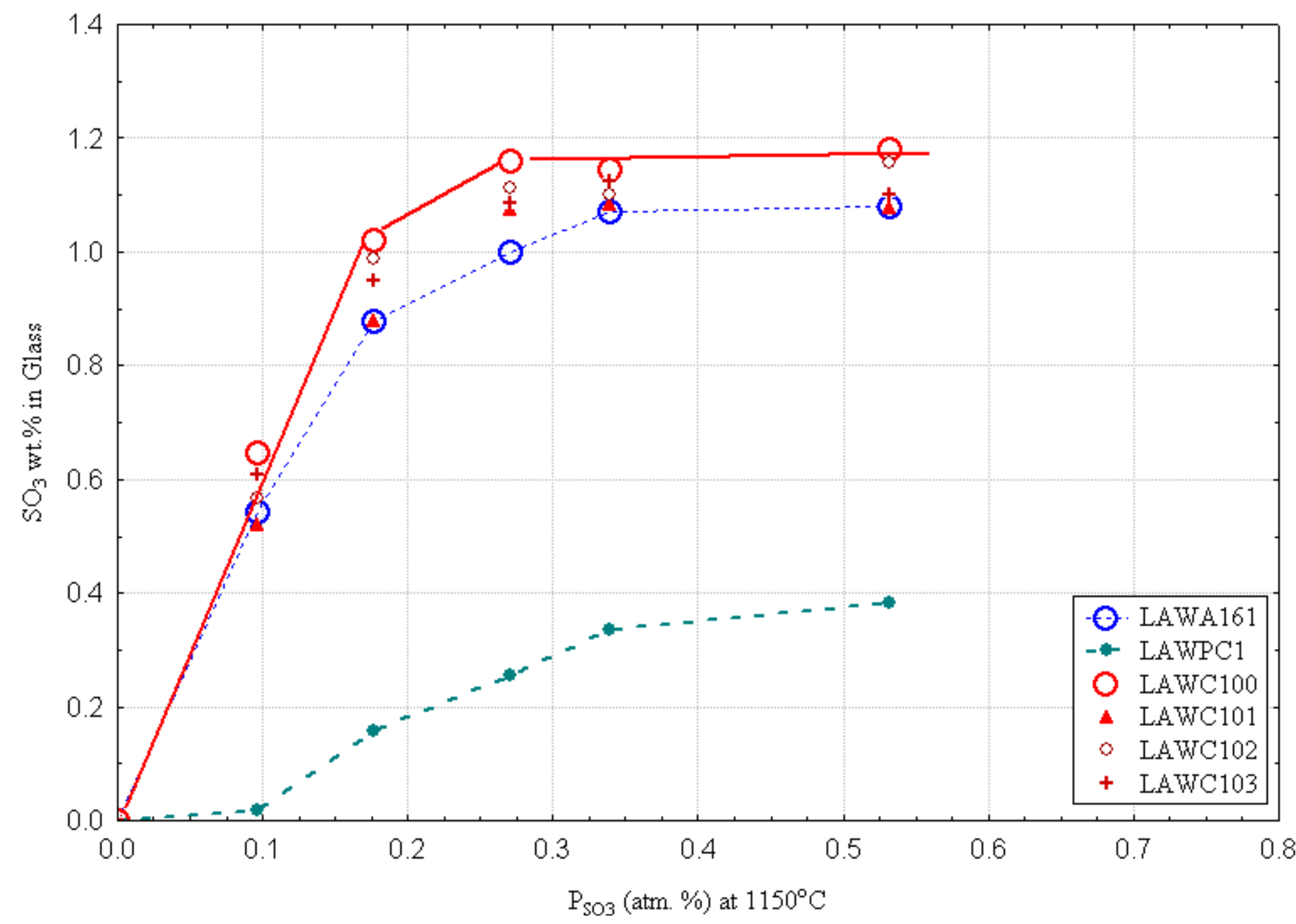

Figure 2.1. Results of $\mathrm{SO}_{2} / \mathrm{O}_{2}$ gas bubbling tests on four new LAW Envelope $\mathrm{C}$ glasses, the previous Envelope $\mathrm{A}$ glass, and an old glass composition at $1150^{\circ} \mathrm{C}$ showing the partial pressure of $\mathrm{SO}_{3}$ vs. the $\mathrm{SO}_{3}$ concentration in the glass melt. The horizontal portions indicate the solubility limits while the slopes at lower concentrations provide measures of the activity coefficient of $\mathrm{SO}_{3}$ in the melt. 


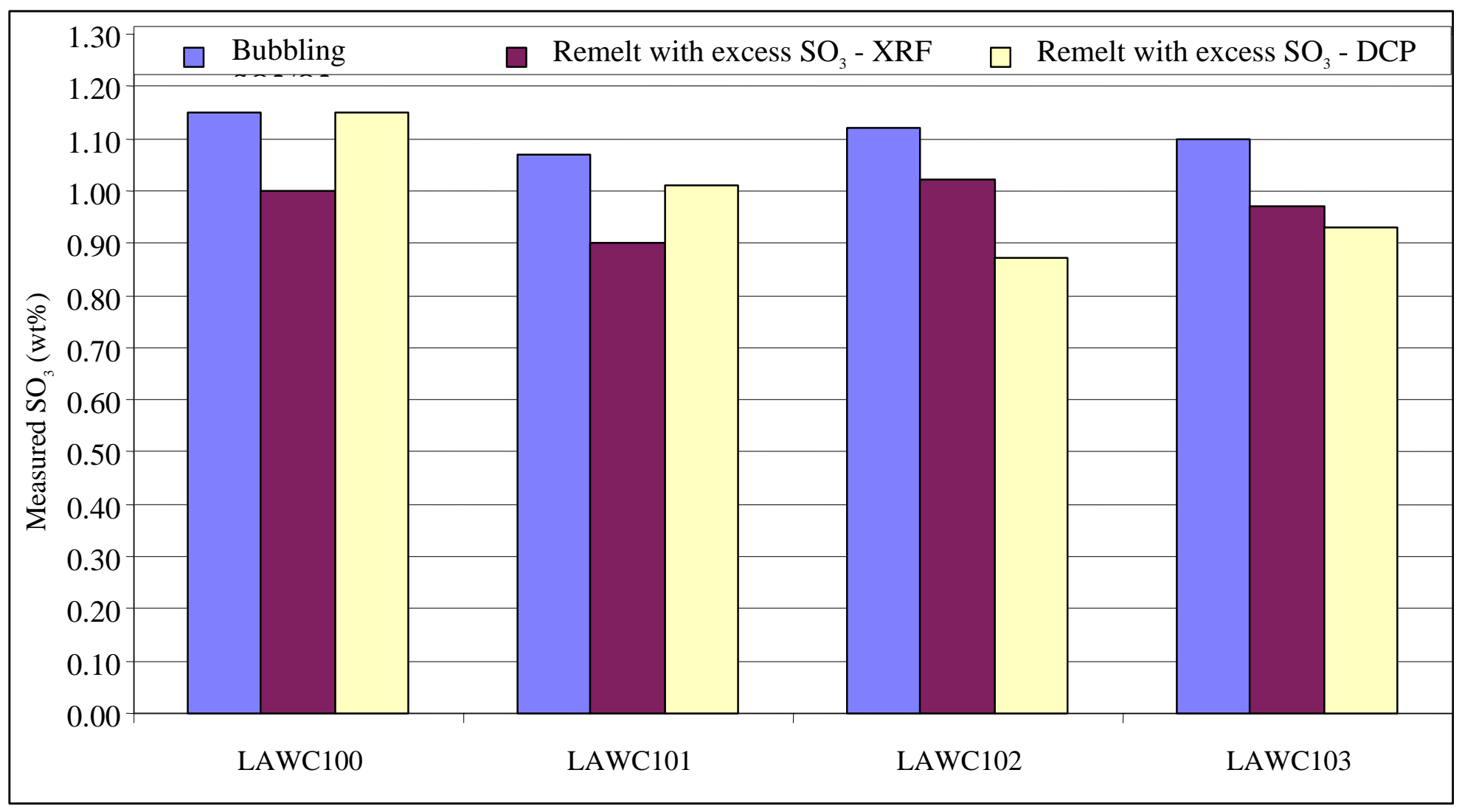

Figure 2.2. Measured sulfate solubility by $\mathrm{SO}_{2} / \mathrm{O}_{2}$ gas bubbling and by remelting with excess $\mathrm{SO}_{3}$ for four new $\mathrm{LAW}$ Envelope $\mathrm{C}$ crucible glasses. 


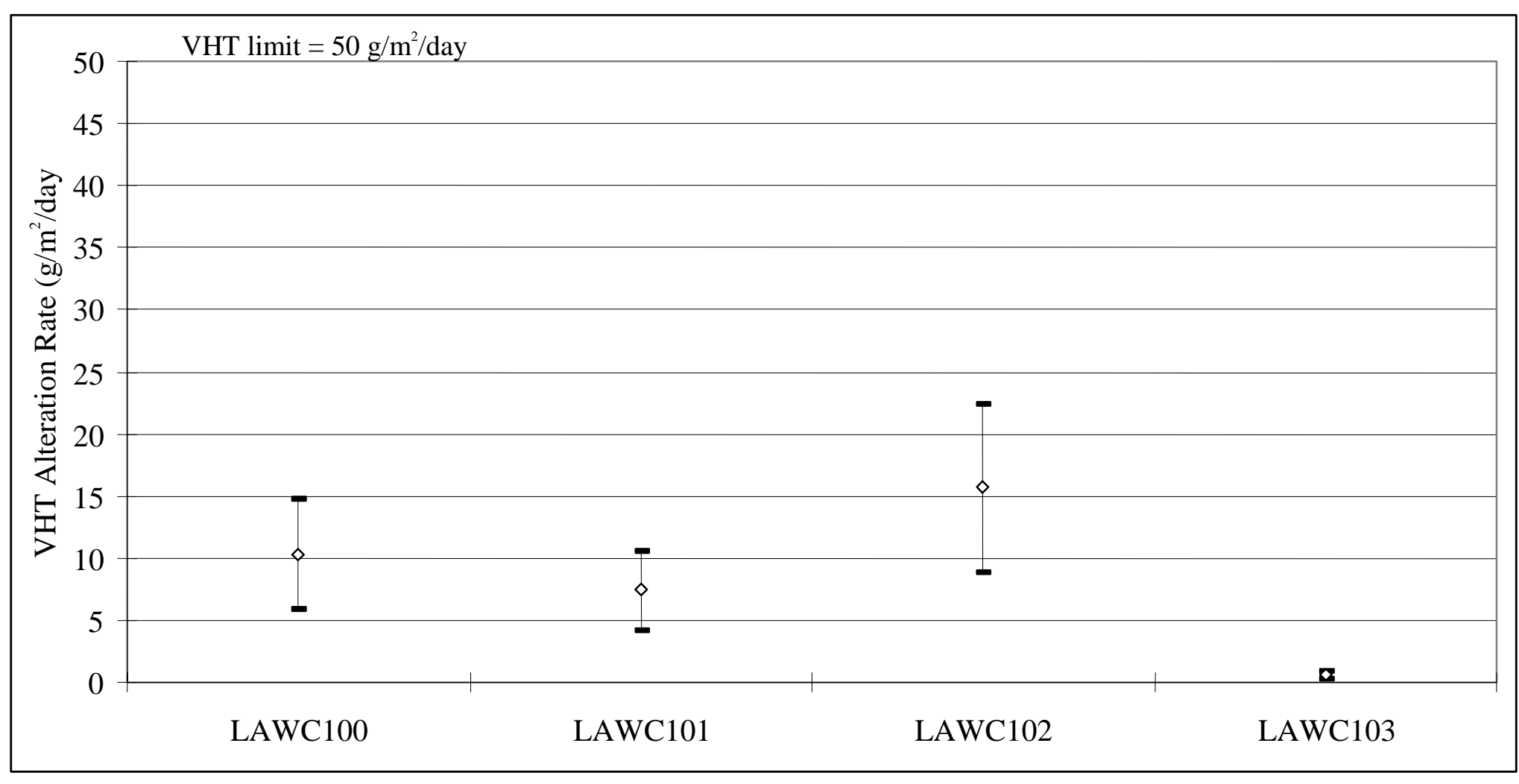

Figure 2.3. VHT results for four new LAW Envelope C crucible glasses. 


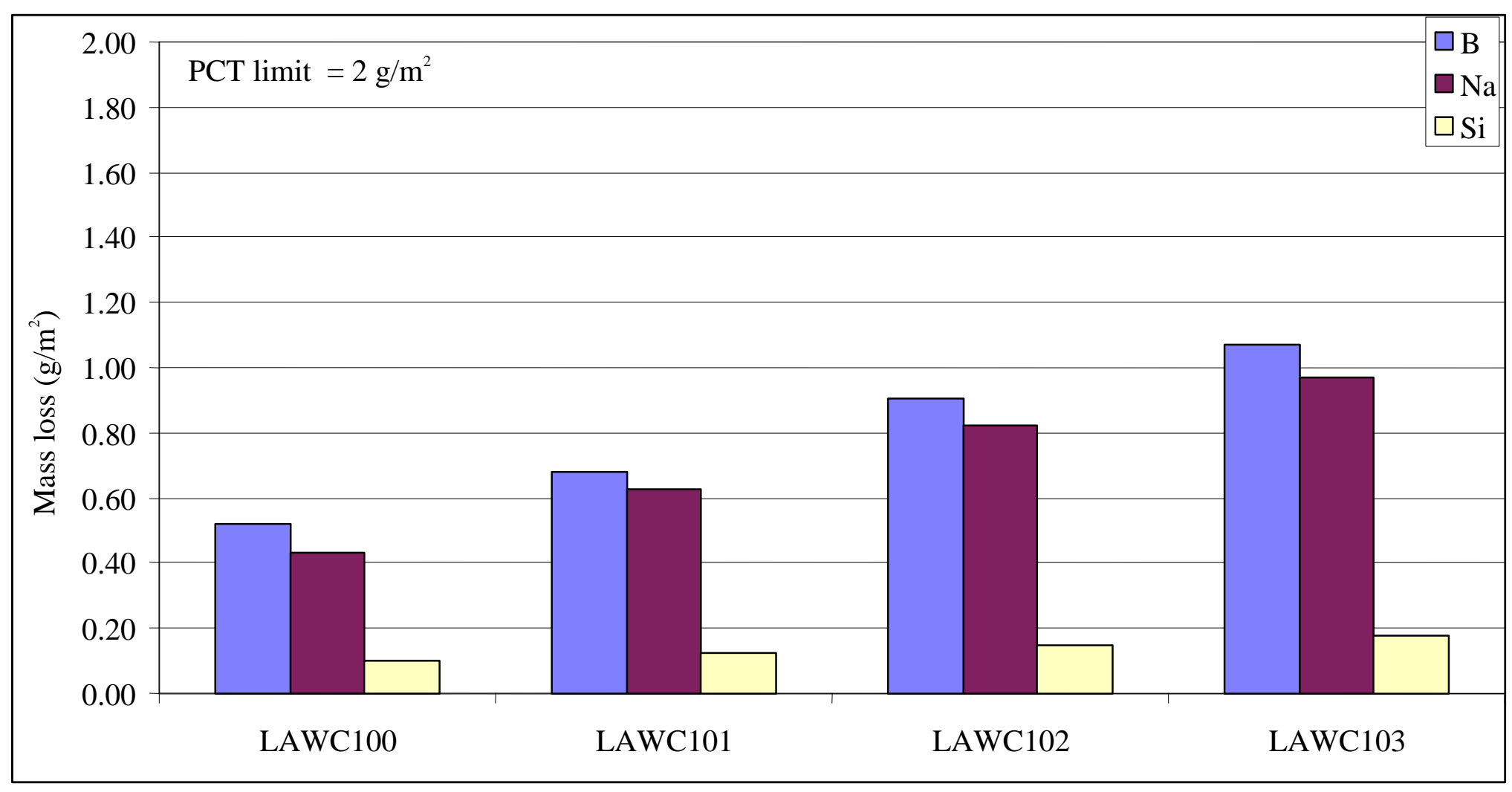

Figure 2.4. Normalized PCT responses for four new LAW Envelope C crucible glasses. 


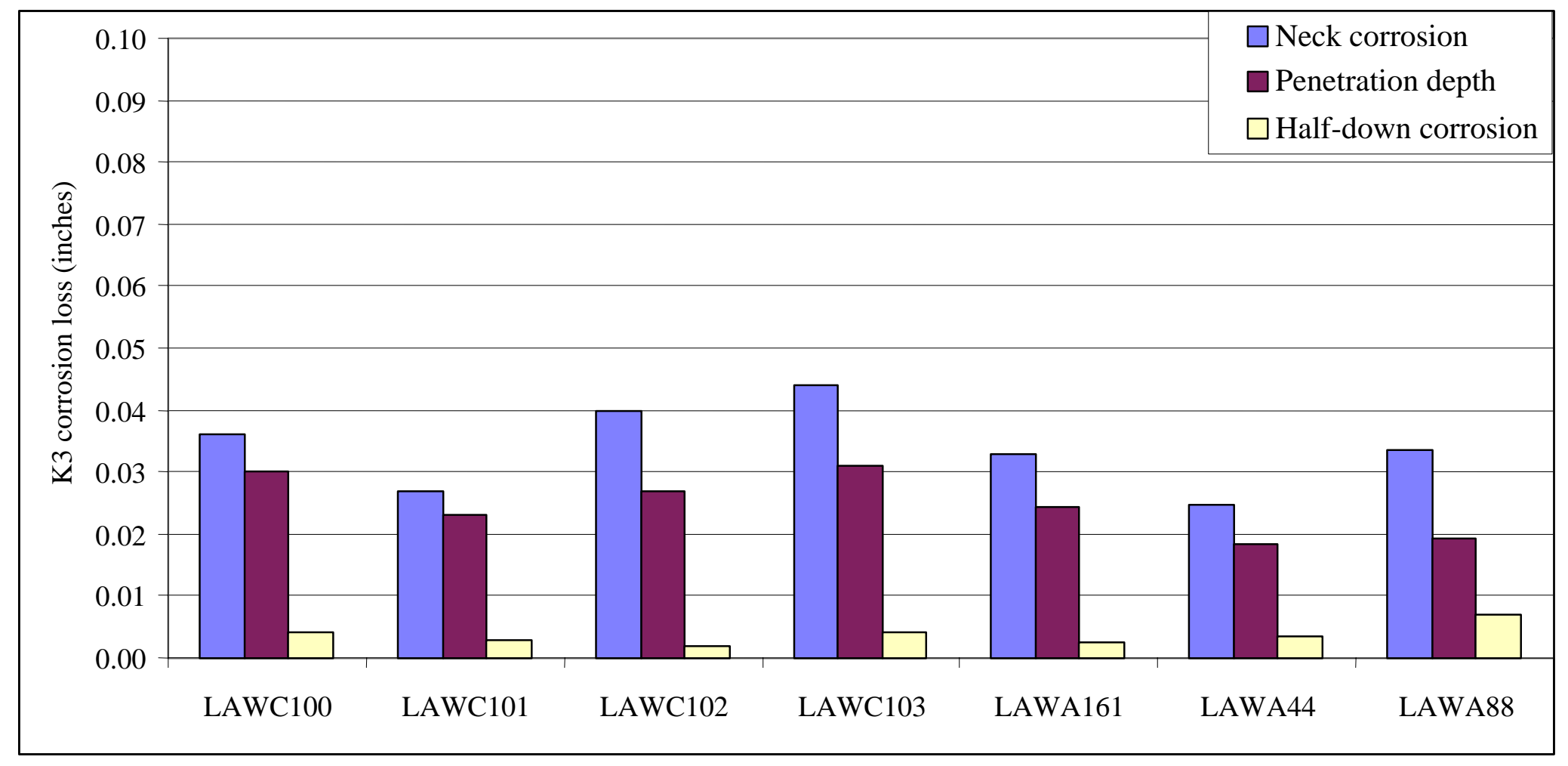

Figure 2.5. K3 Corrosion results for four new LAW Envelope C crucible glasses and three old LAW formulations. 


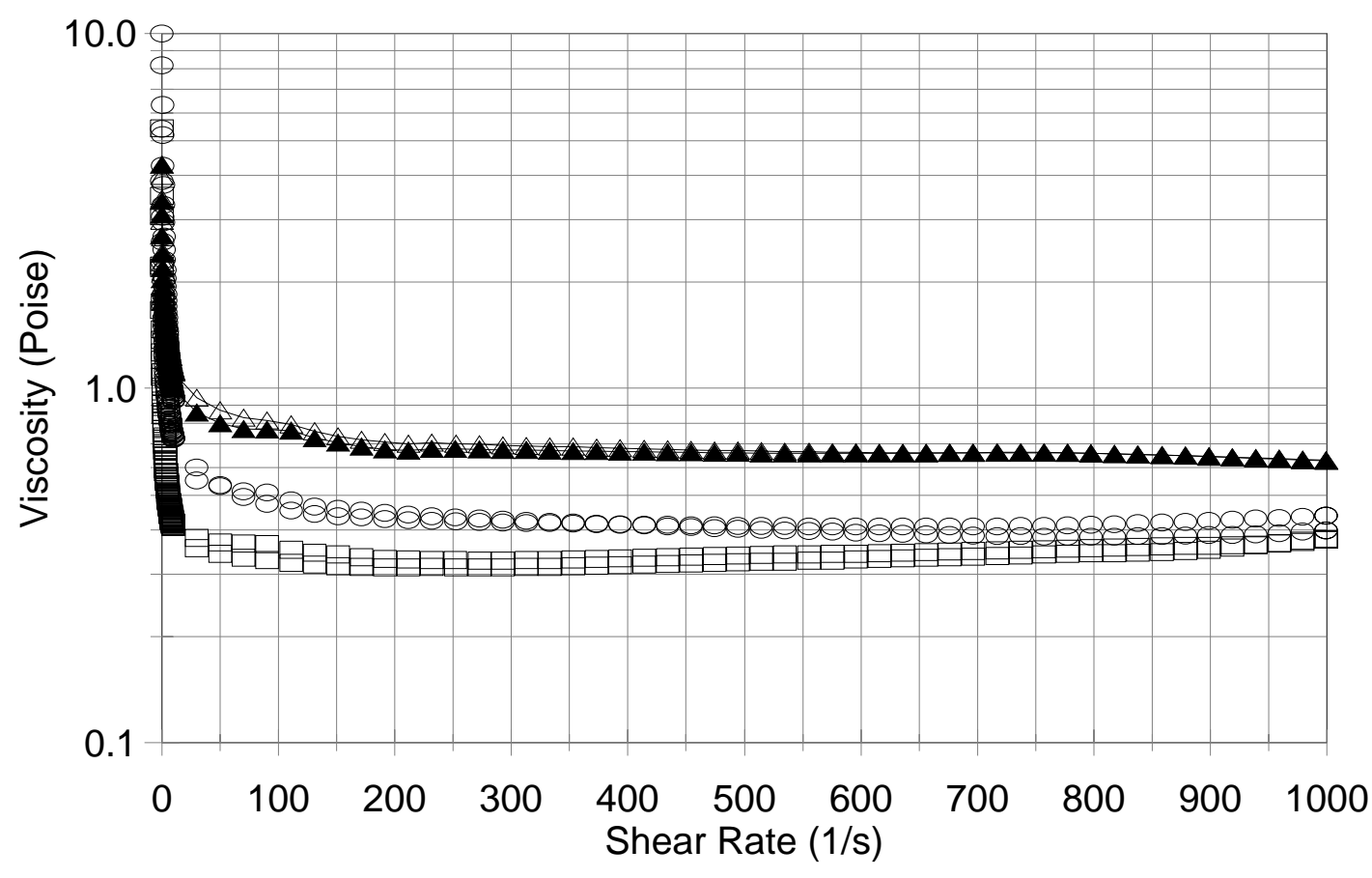

$\begin{array}{ll}\text { Current Test (LAWC100) } & \square \text { Previous Tests (LAWA161) } \\ \triangle \text { Crucible Feed(LAWC100@0.75wt\% SO3) } & -\quad \text { Crucible Feed(LAWC100@1.5wt\% SO3) }\end{array}$

Figure 2.6. Measured viscosity of LAW melter and crucible feed samples. 

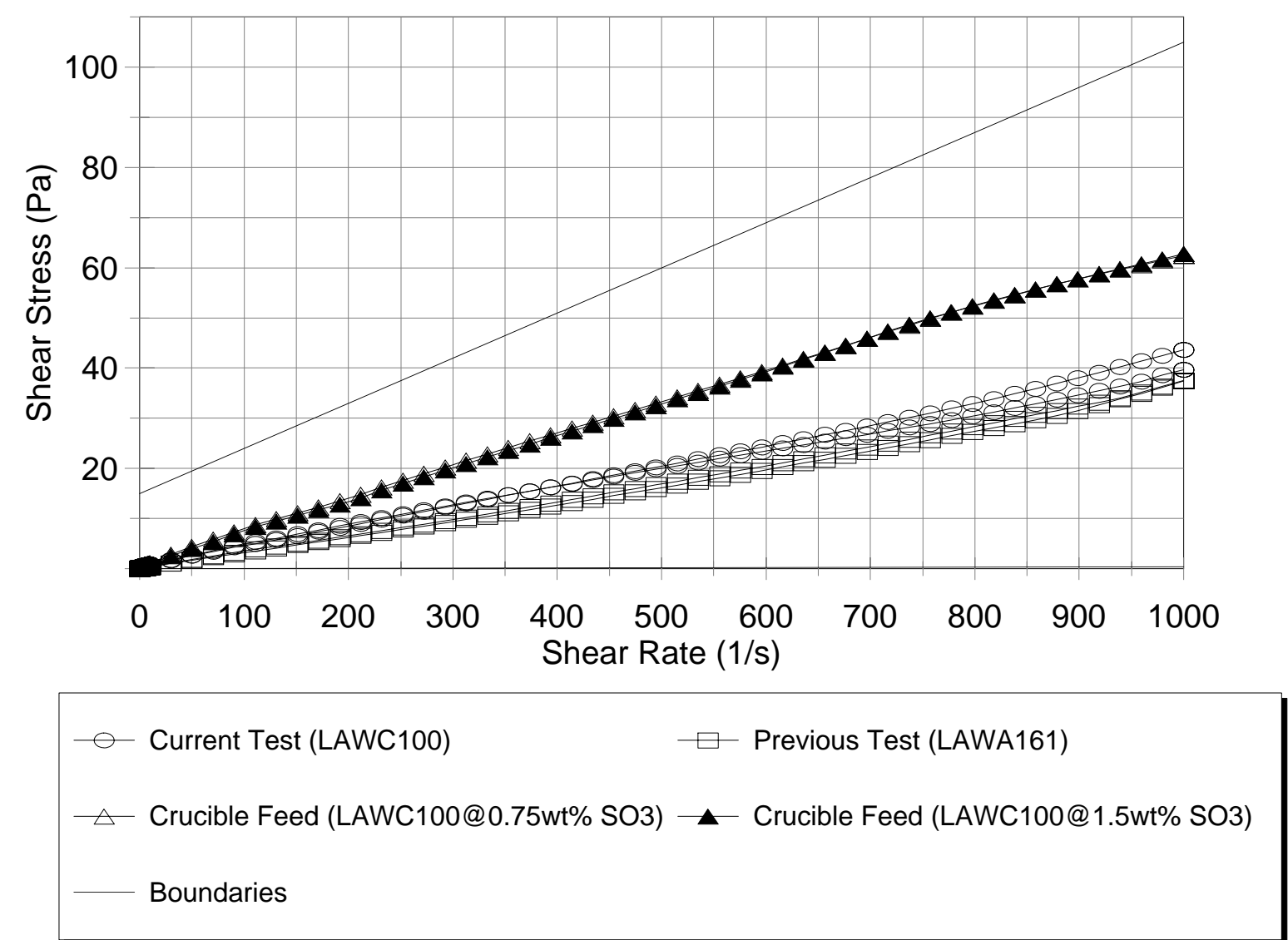

Figure 2.7. Comparison of measured feed rheology with proposed WTP bounds (bounds from WTP-RPT-075, Rev. 0, Feb. 2003). 


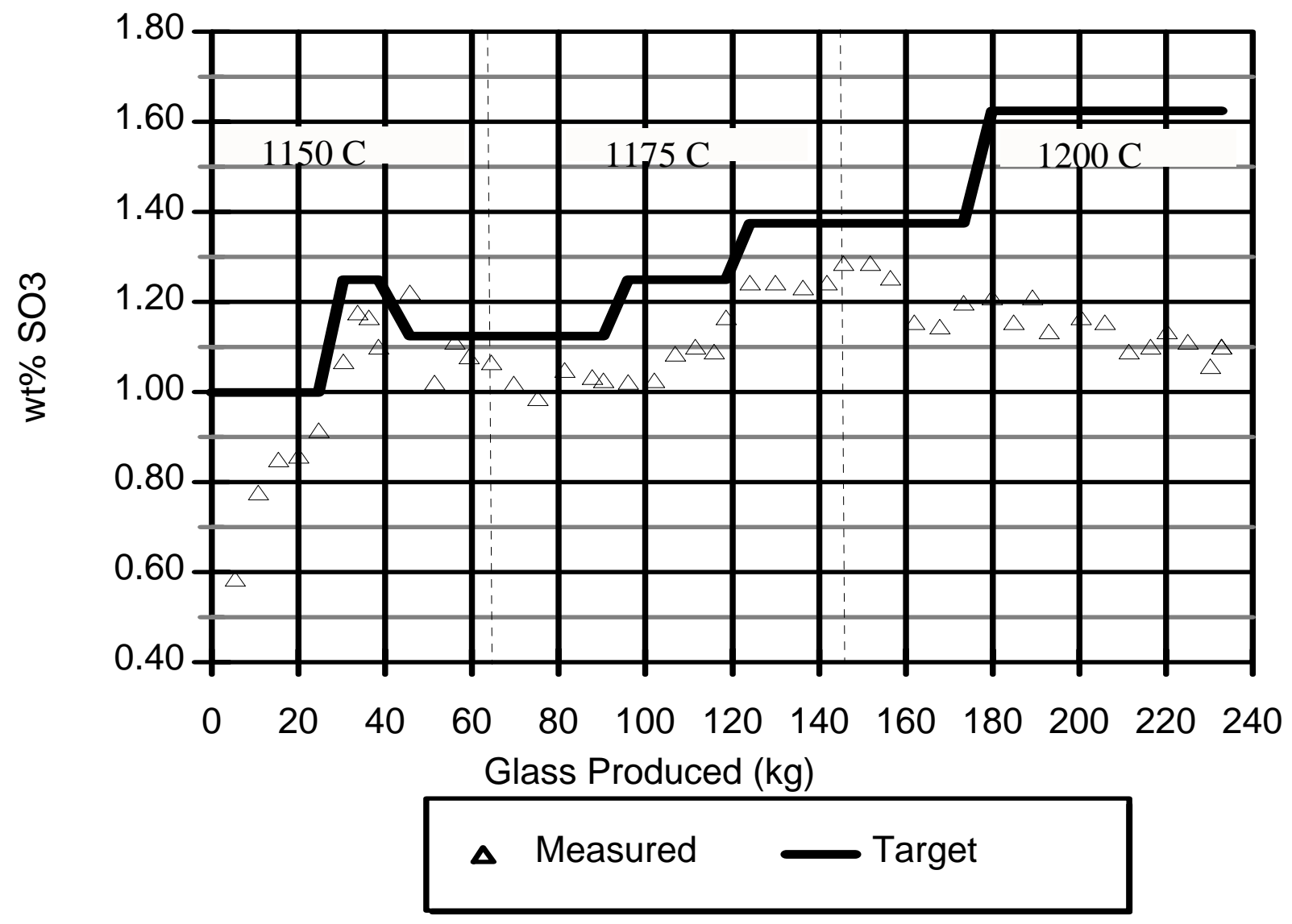

Figure 3.1. XRF analysis of sulfur in DM10 product glasses. 


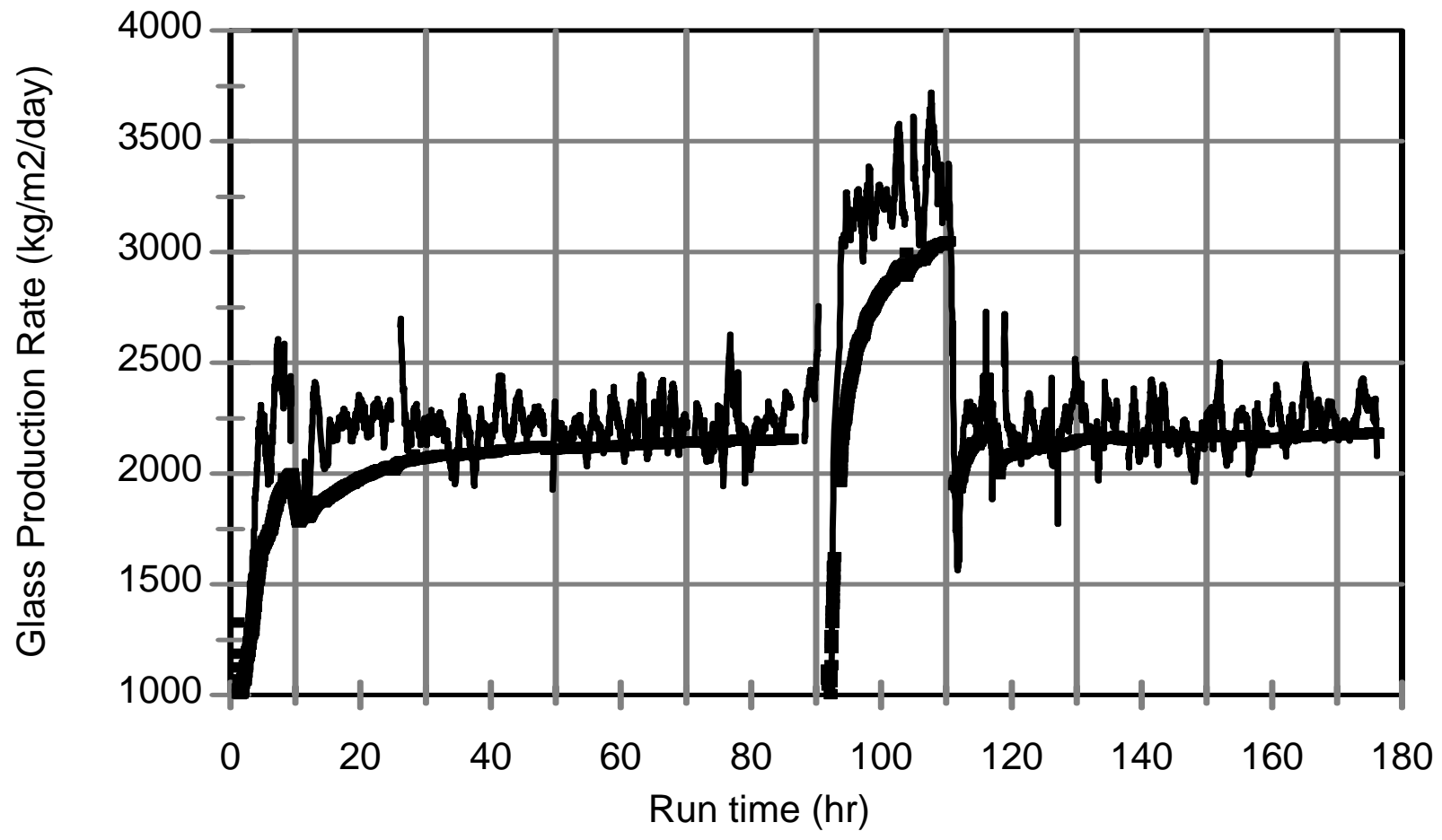

$1 \mathrm{hr}$ moving avg.

- Cumulative

Figure 4.1. Glass production rates for the DM100 LAW Envelope C tests.

Note: Cumulative curve calculated in 3 segments; Test 1, Test 2a, and Tests $2 b-2 e$. 


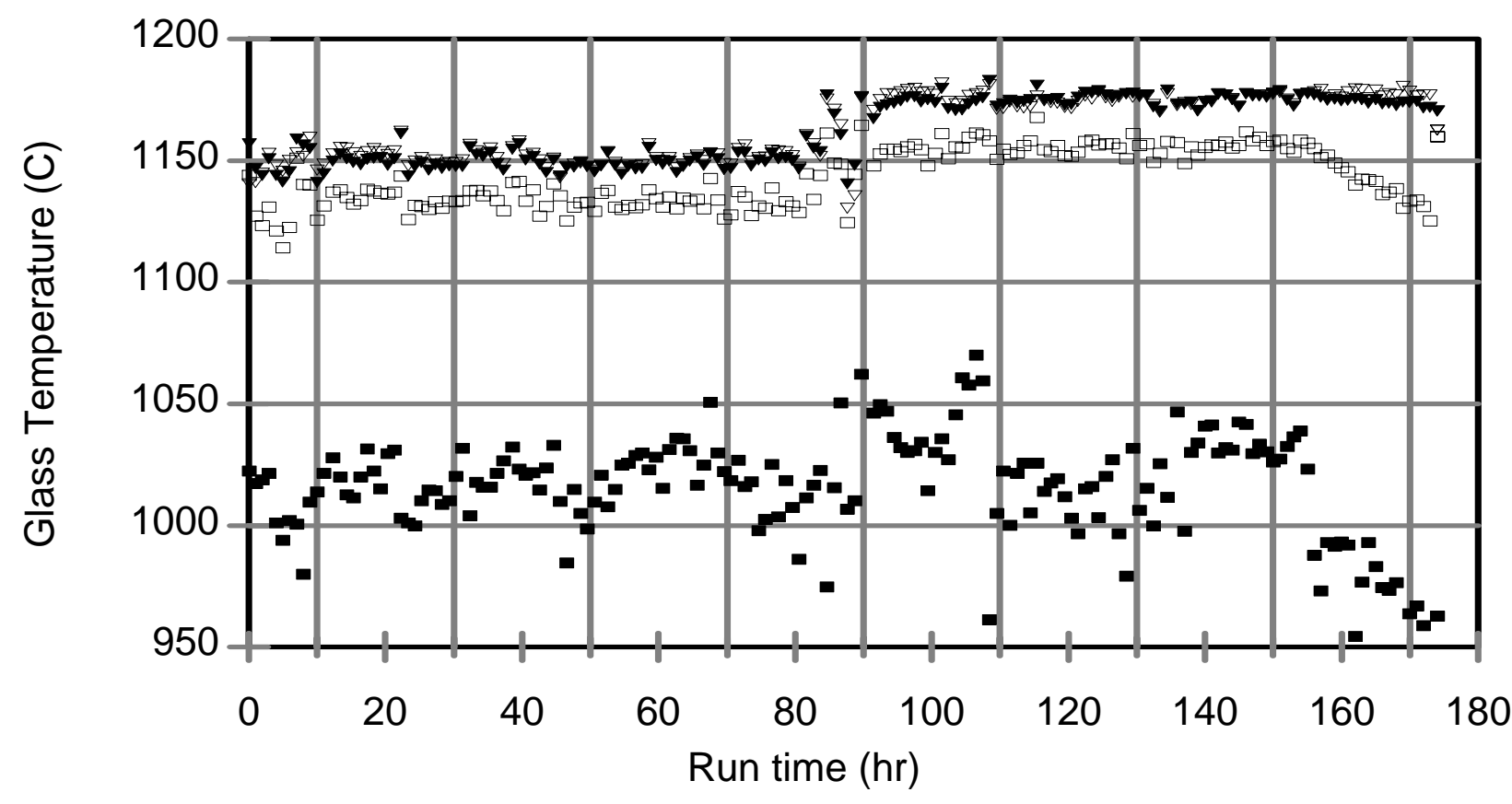

- 19" from floor

- 10 " from floor
- 16 " from floor

- 4" from floor

Figure 4.2. Glass temperatures for the DM100 LAW Envelope C tests. 


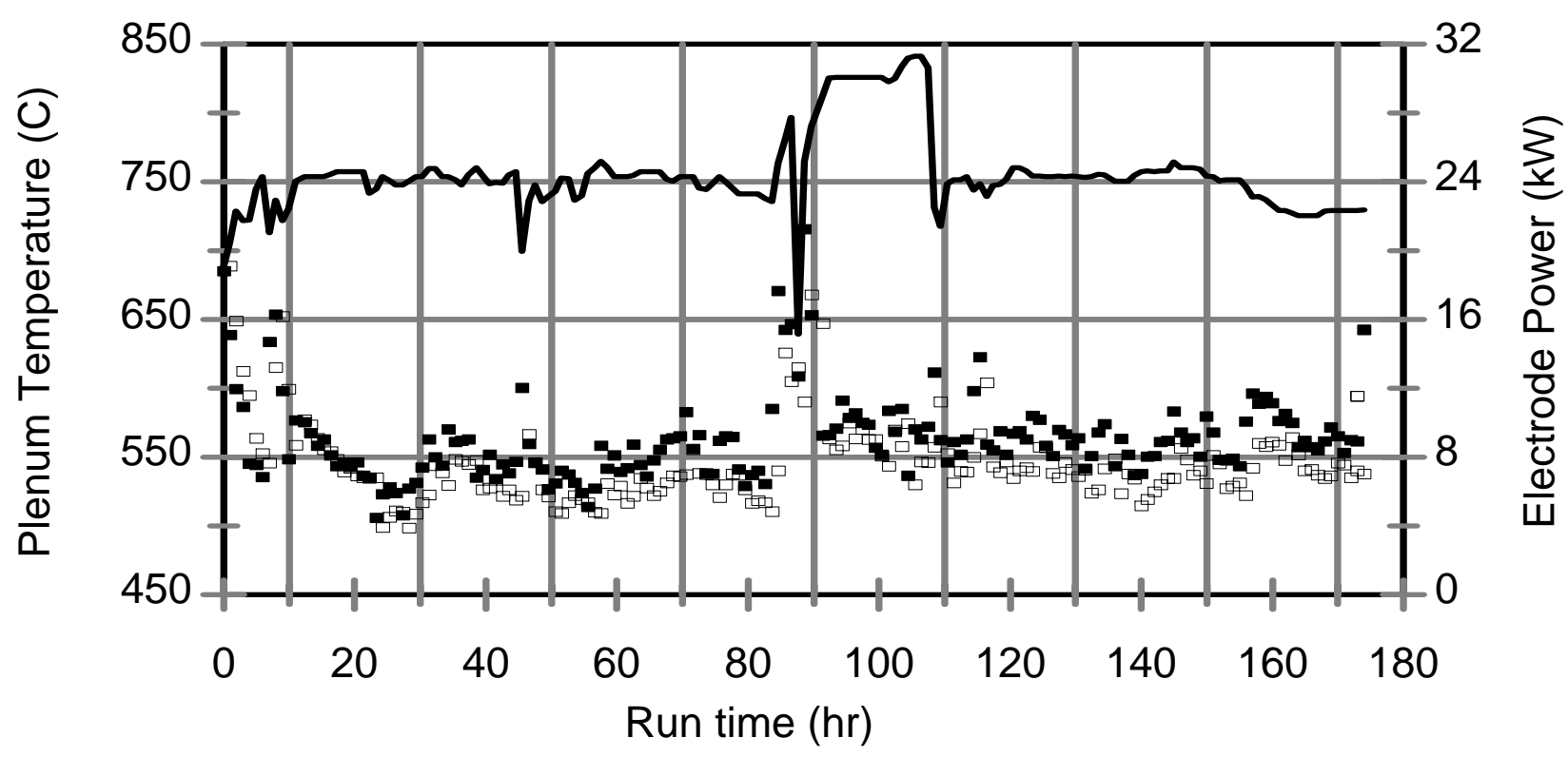

- 16" below ceiling (exposed)

- 16 " below ceiling (thermowell)

Electrode Power

Figure 4.3. Plenum temperatures and electrode power for the DM100 LAW Envelope C tests. 


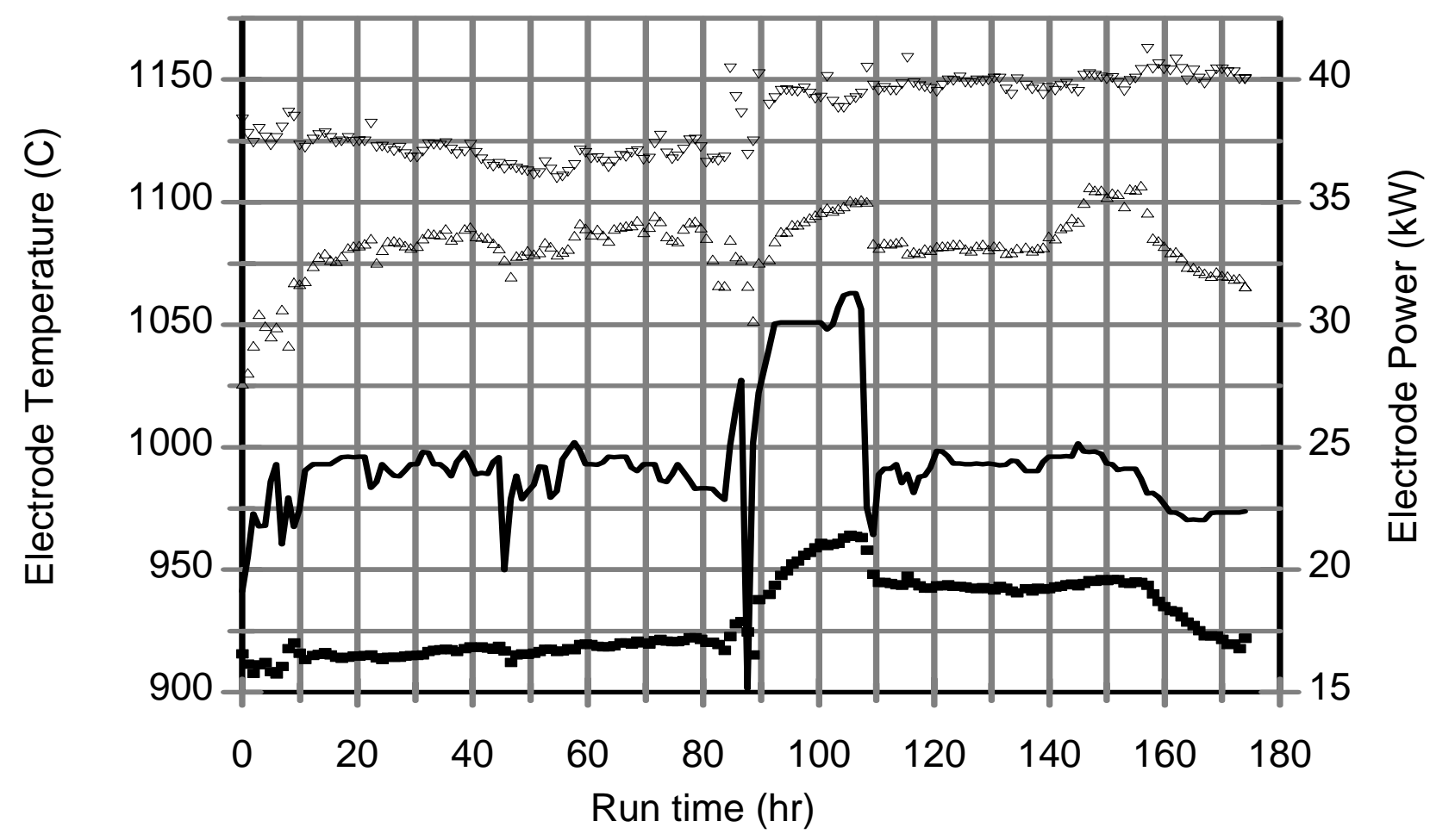

- East

- West

- Bottom - Power

Figure 4.4. Electrode temperature and power for the DM100 LAW Envelope C tests. 


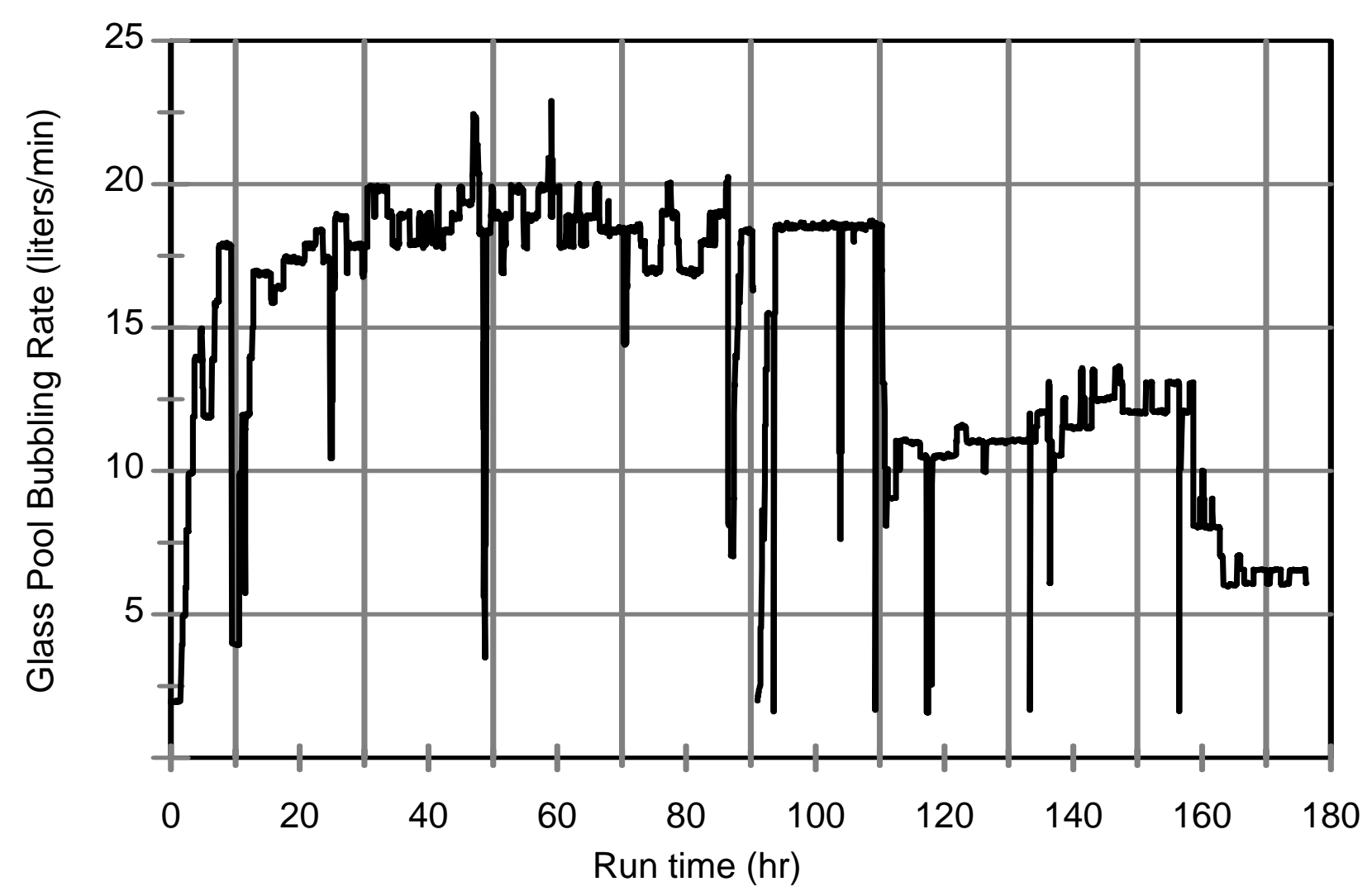

Figure 4.5. Glass pool bubbling rate during DM100 LAW Envelope C tests. 


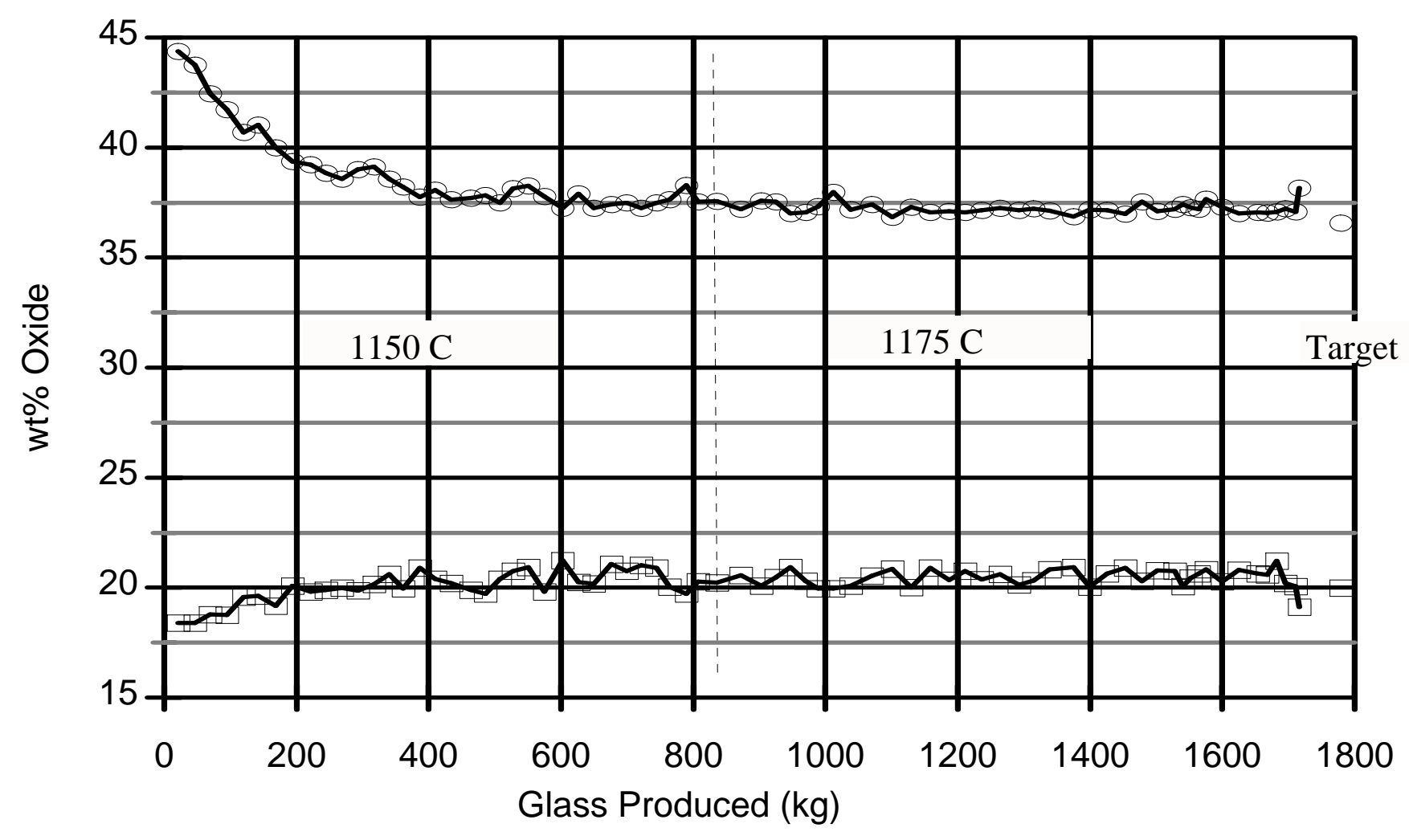

$$
\rightarrow \mathrm{Na}-\mathrm{Si}
$$

Figure 5.1. $\mathrm{XRF}$ analysis of $\mathrm{Na}_{2} \mathrm{O}$ and $\mathrm{SiO}_{2}$ in $\mathrm{DM100}$ product glasses. 


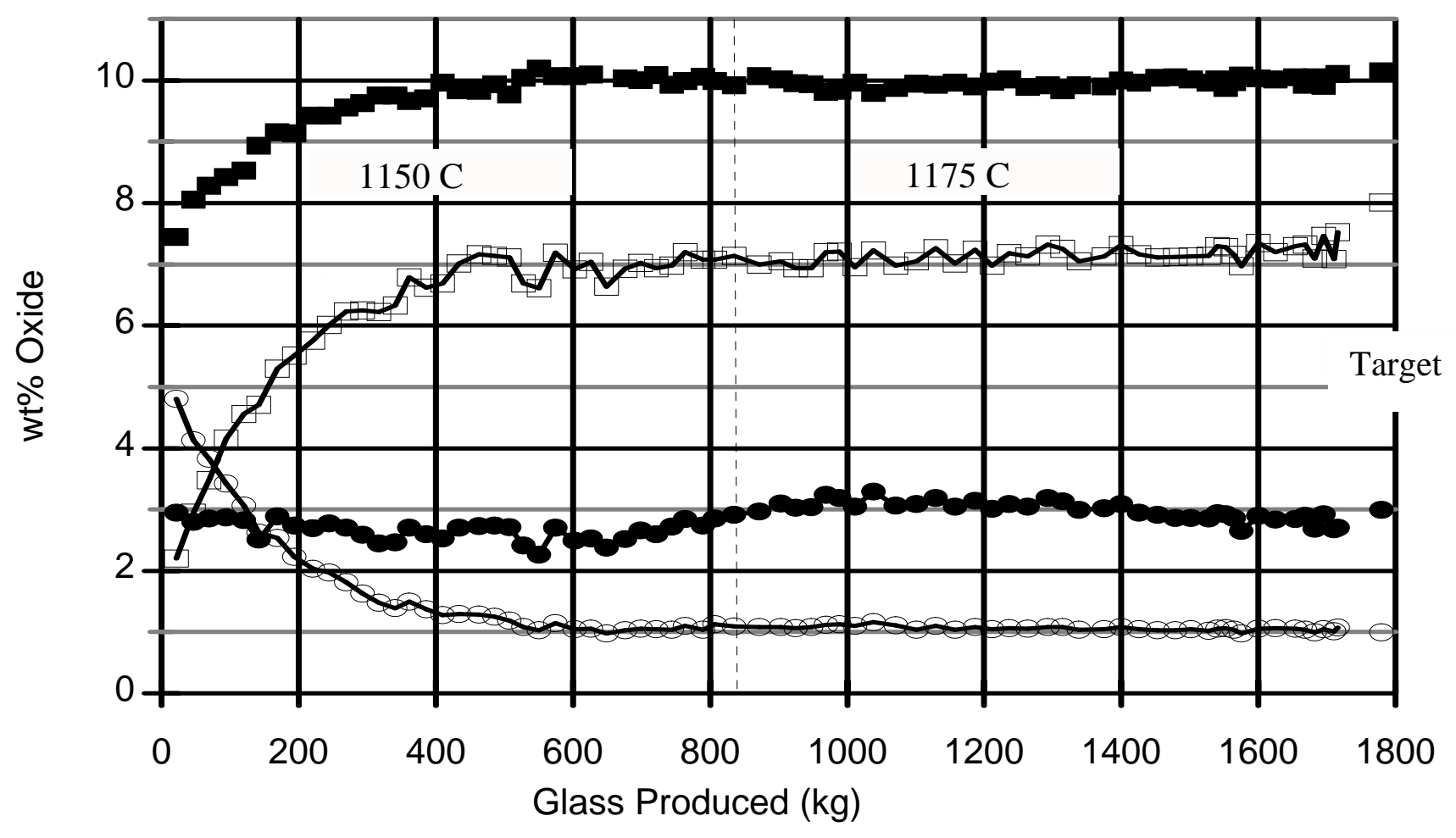

$$
\text { - Al } \quad \text { - } \mathrm{Ca} \text { - } \mathrm{Fe} \rightarrow \mathrm{Zr}
$$

Figure 5.2. XRF analysis of select major oxides in DM100 product glasses. 


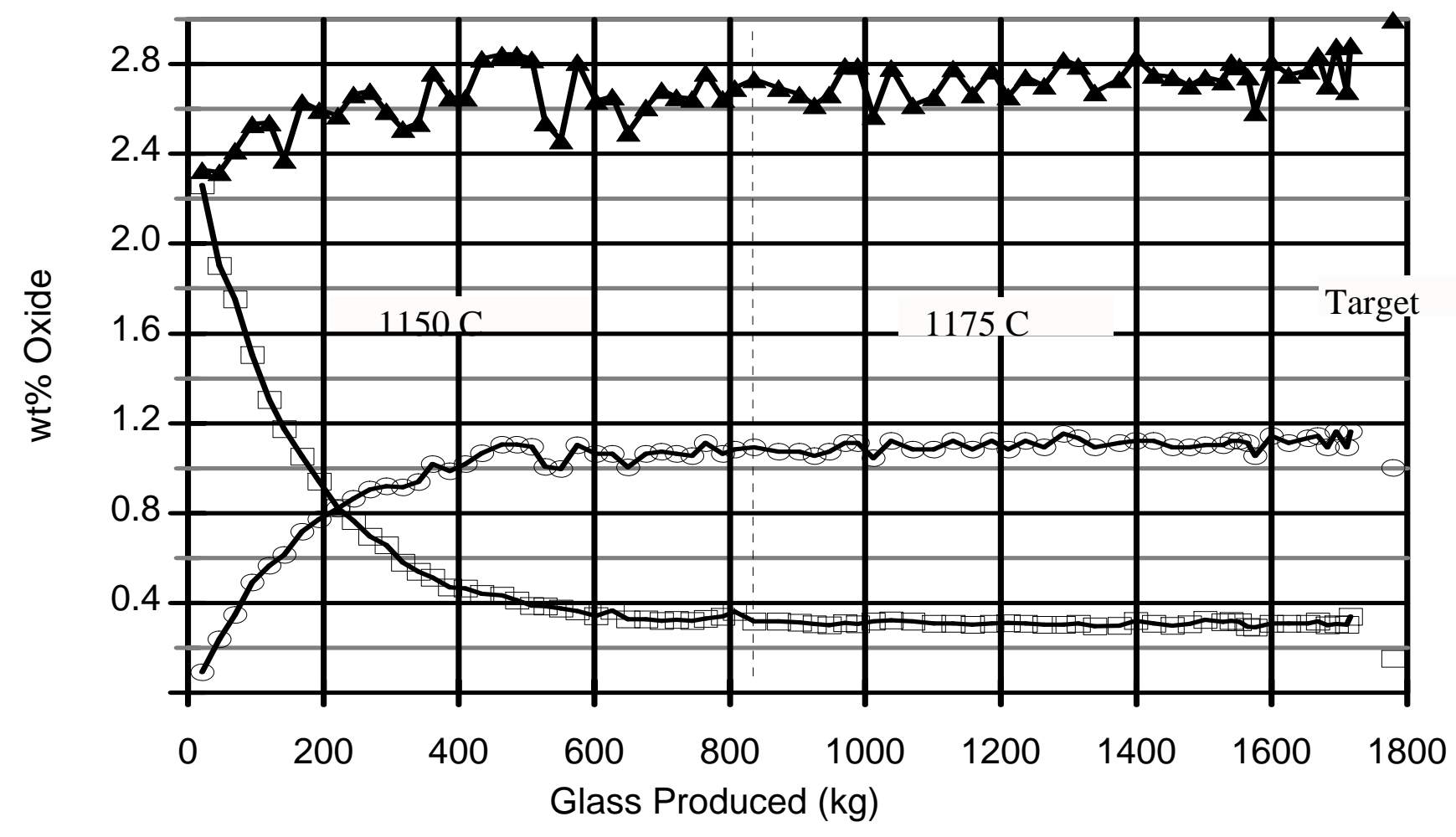

$$
\because \mathrm{K}-\mathrm{C} \mathrm{V} \rightarrow \mathrm{Zn}
$$

Figure 5.3. XRF analysis of potassium, vanadium, and zinc oxides in DM100 product glasses. 


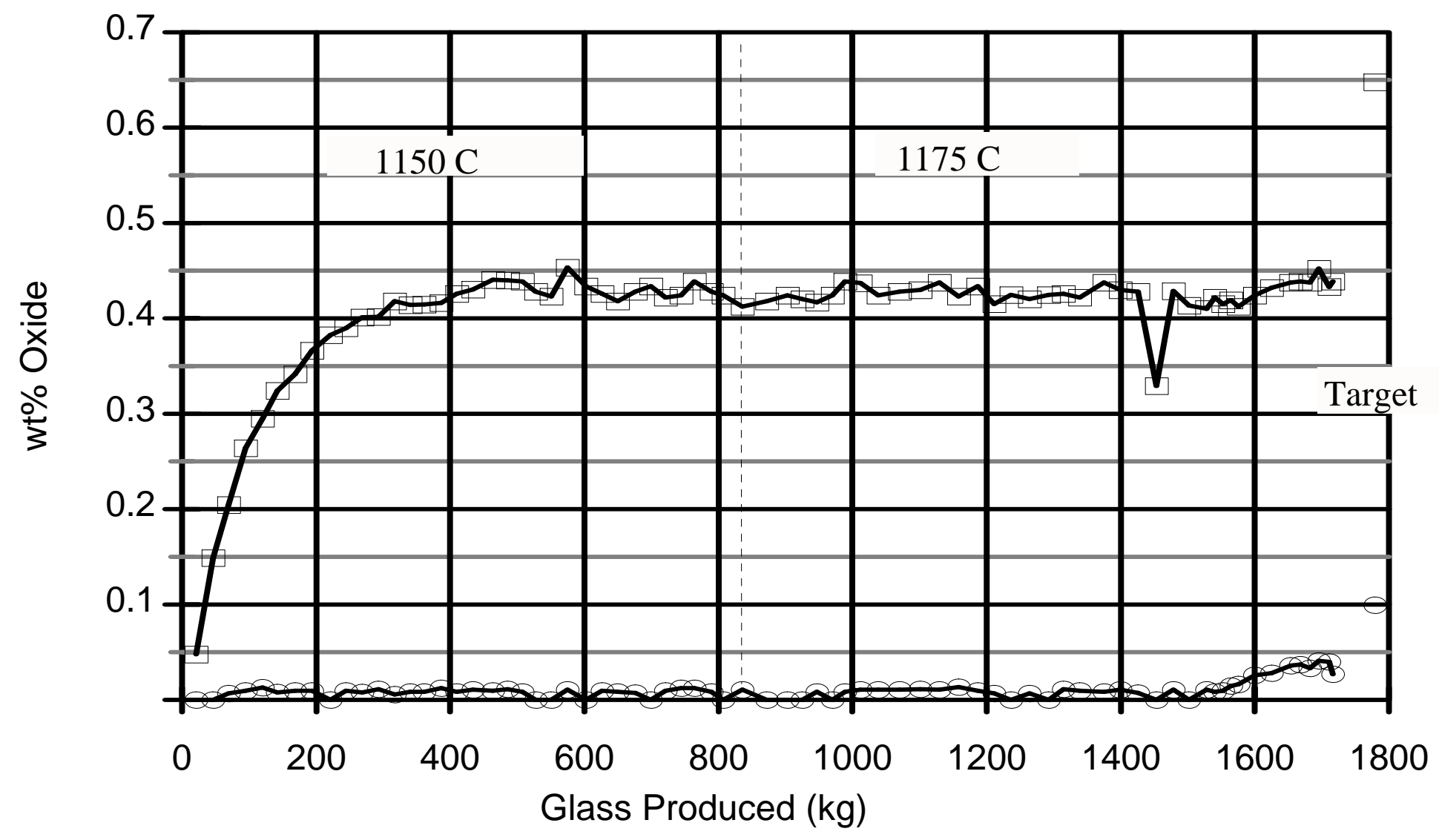

Figure 5.4. XRF analysis of chlorine and iodine in DM100 product glasses. 


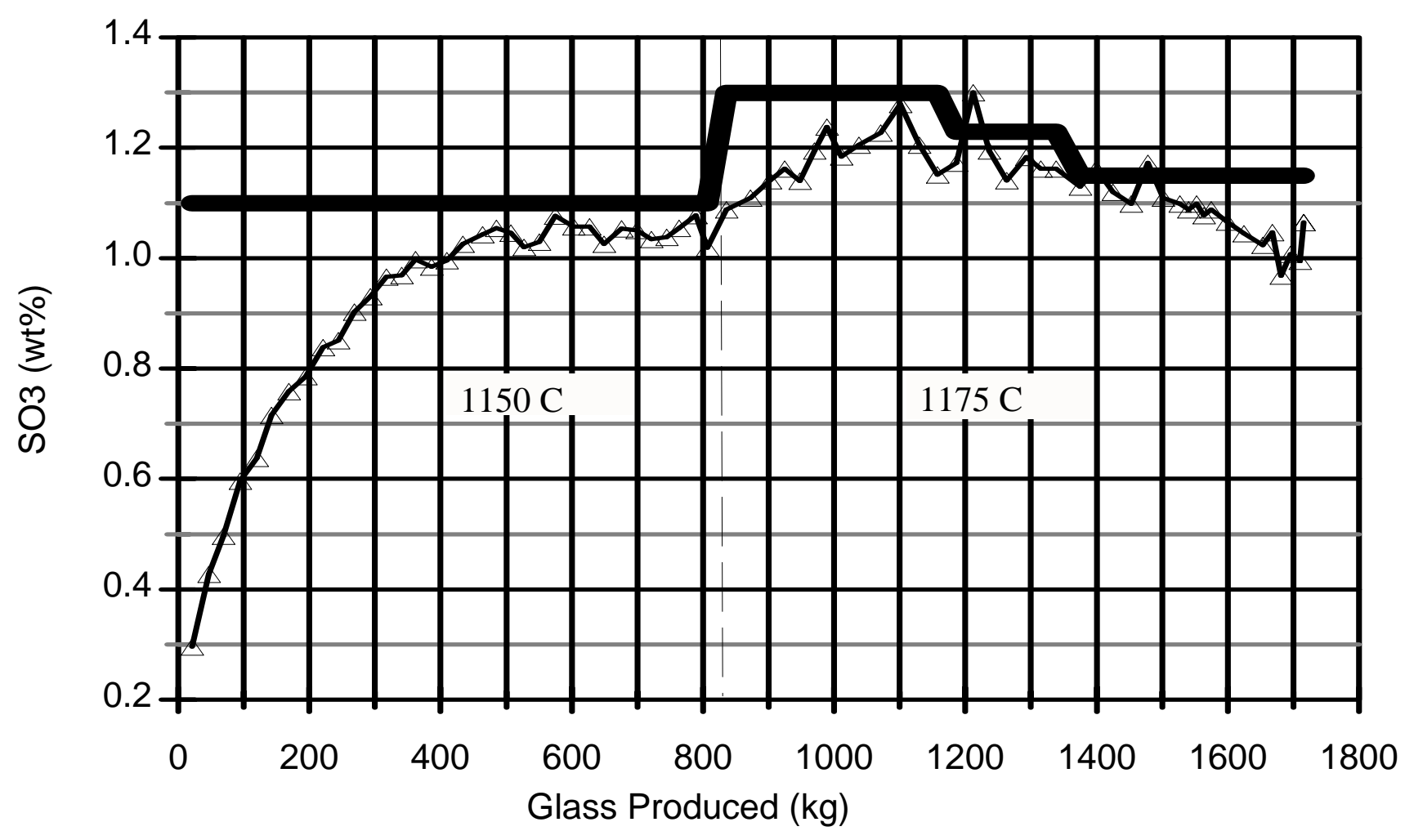

$$
\triangle \text { Measured } \rightleftharpoons \text { Target }
$$

Figure 5.5. XRF analysis of sulfur in DM100 product glasses. 


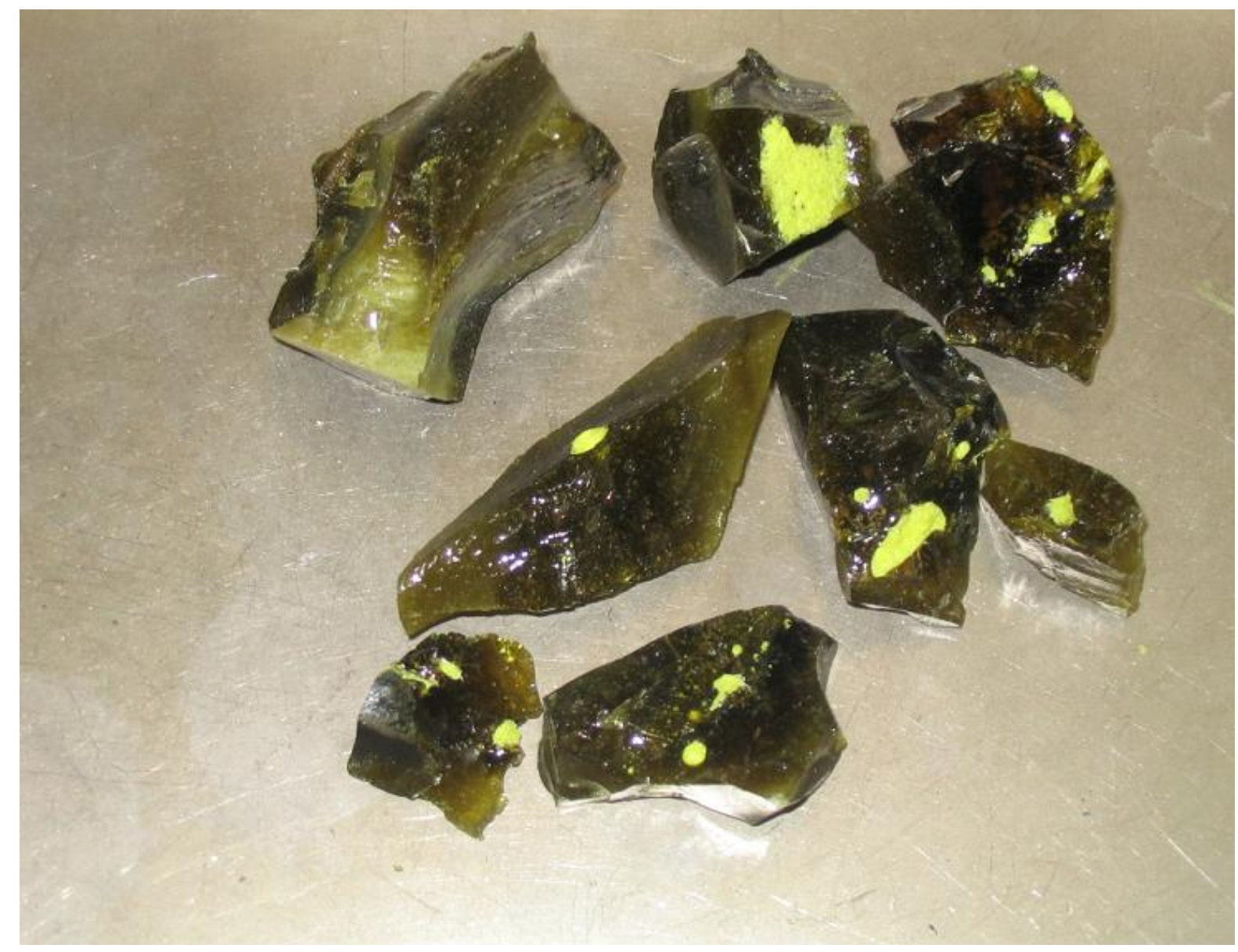

Figure 5.6. Secondary phases in discharged glass (WVY-G-121B/C, $1.3 \mathrm{wt} \% \mathrm{SO}_{3}$ in feed). 


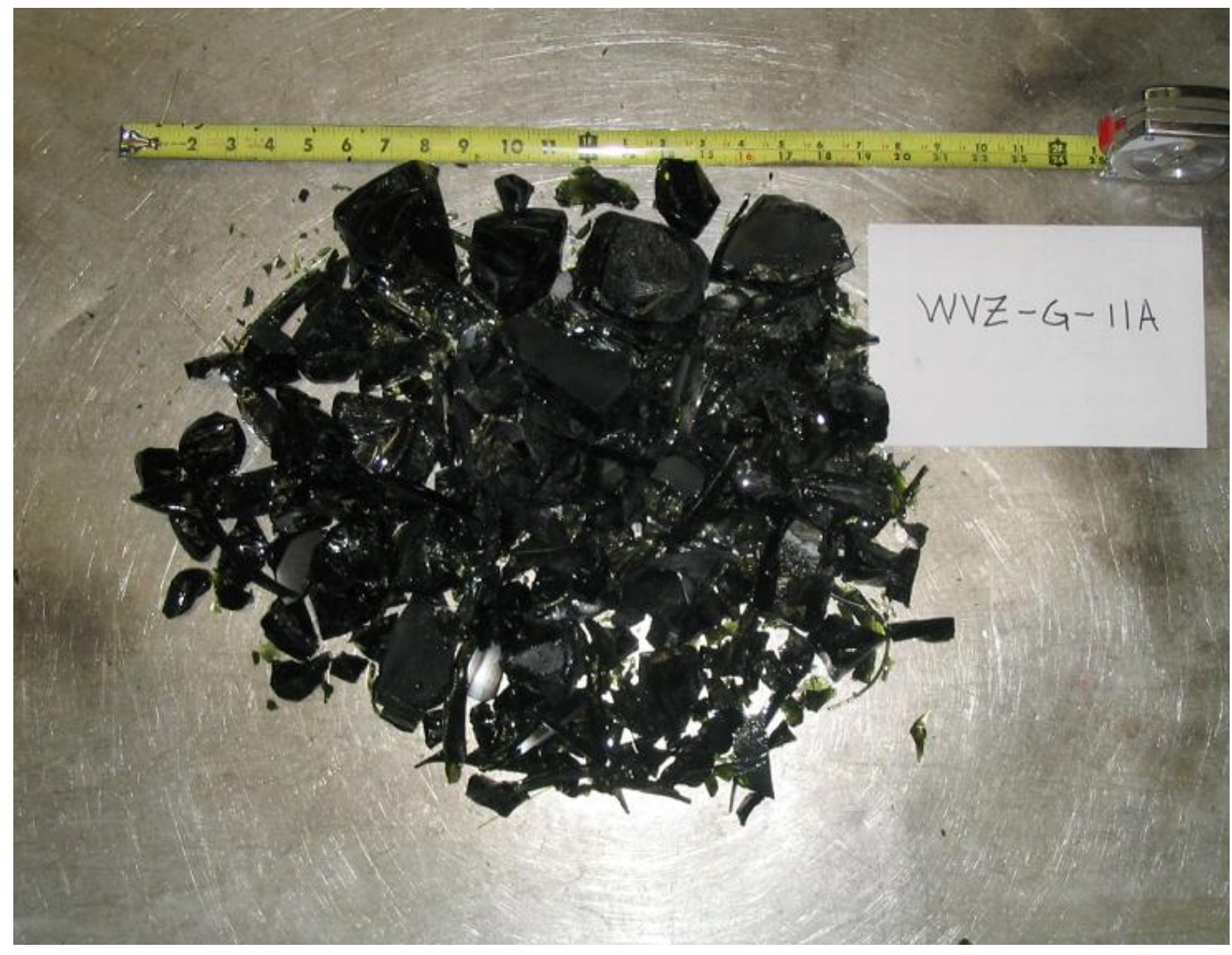

Figure 5.7.a Entire glass discharge from end of tests (WVZ-G-11A, 1.15 wt $\% \mathrm{SO}_{3}$ in feed, additional sugar). 


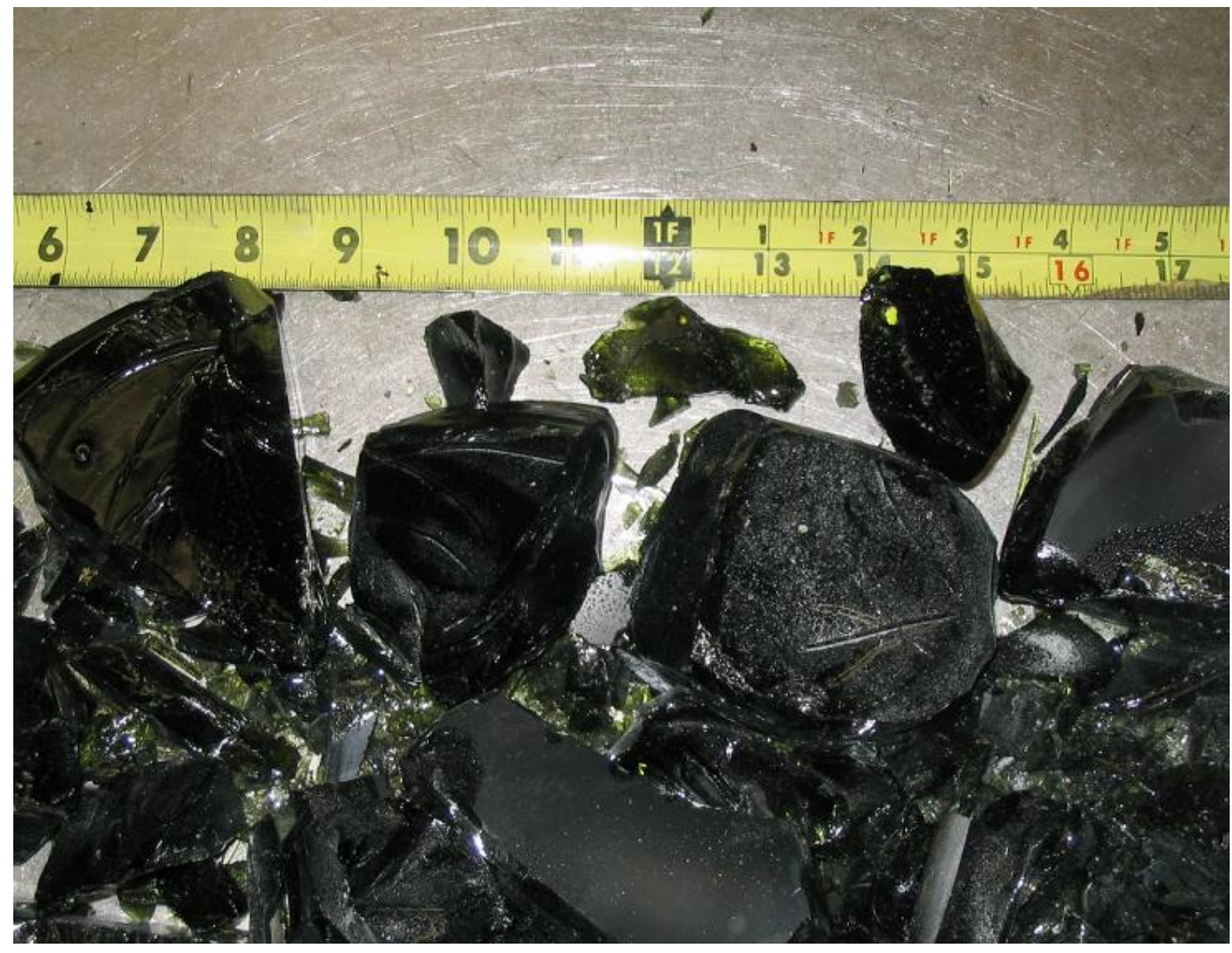

Figure 5.7.b Close-up of glass discharge from end of tests showing small sulfate inclusion (single yellow spot, top right; WVZ-G-11A, 1.15 wt. $\% \mathrm{SO}_{3}$ in feed, additional sugar). 


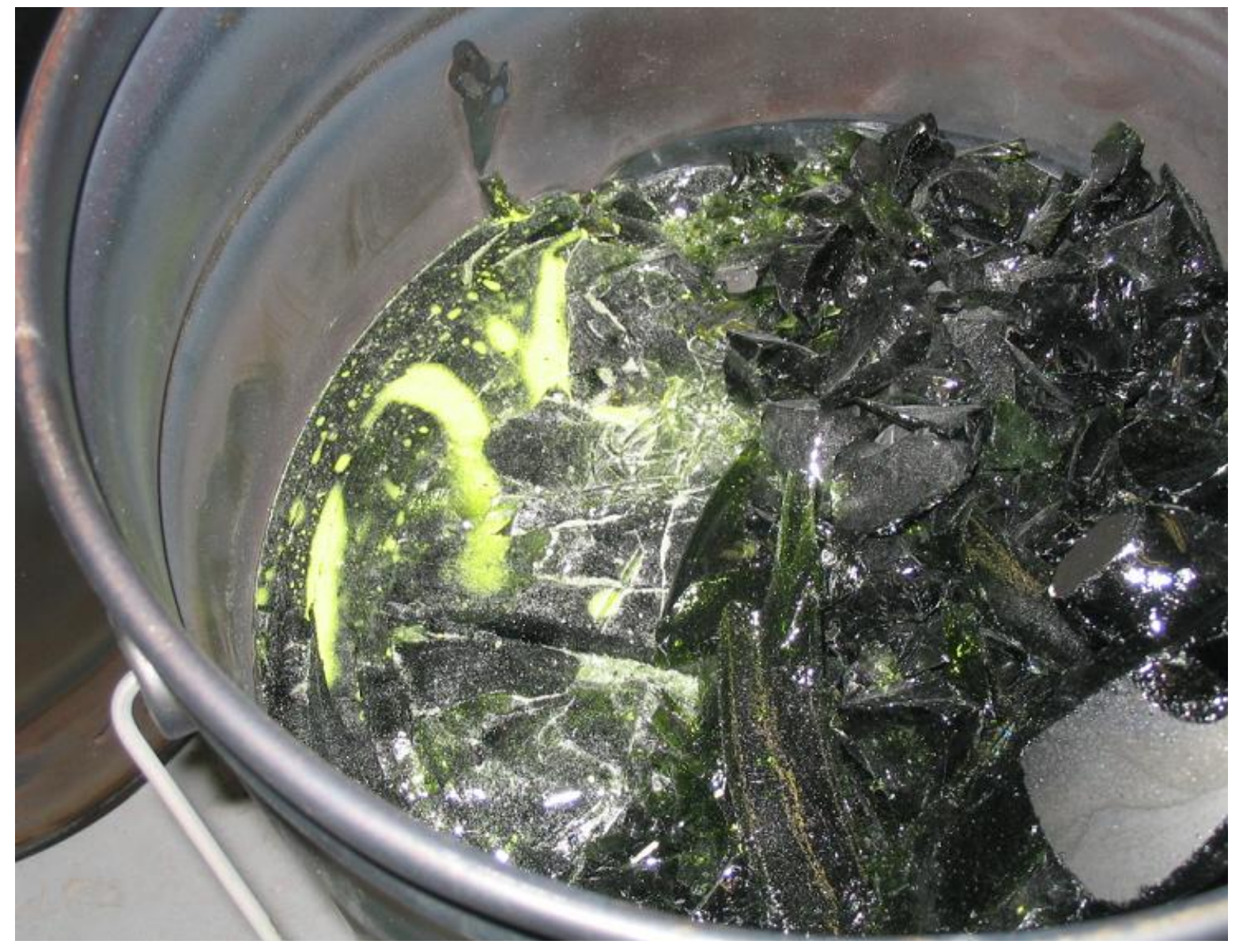

Figure 5.8. Sulfate on surface of discharged glass (WVY-G-155B, $1.15 \mathrm{wt} \% \mathrm{SO}_{3}$ in feed, additional sugar). 


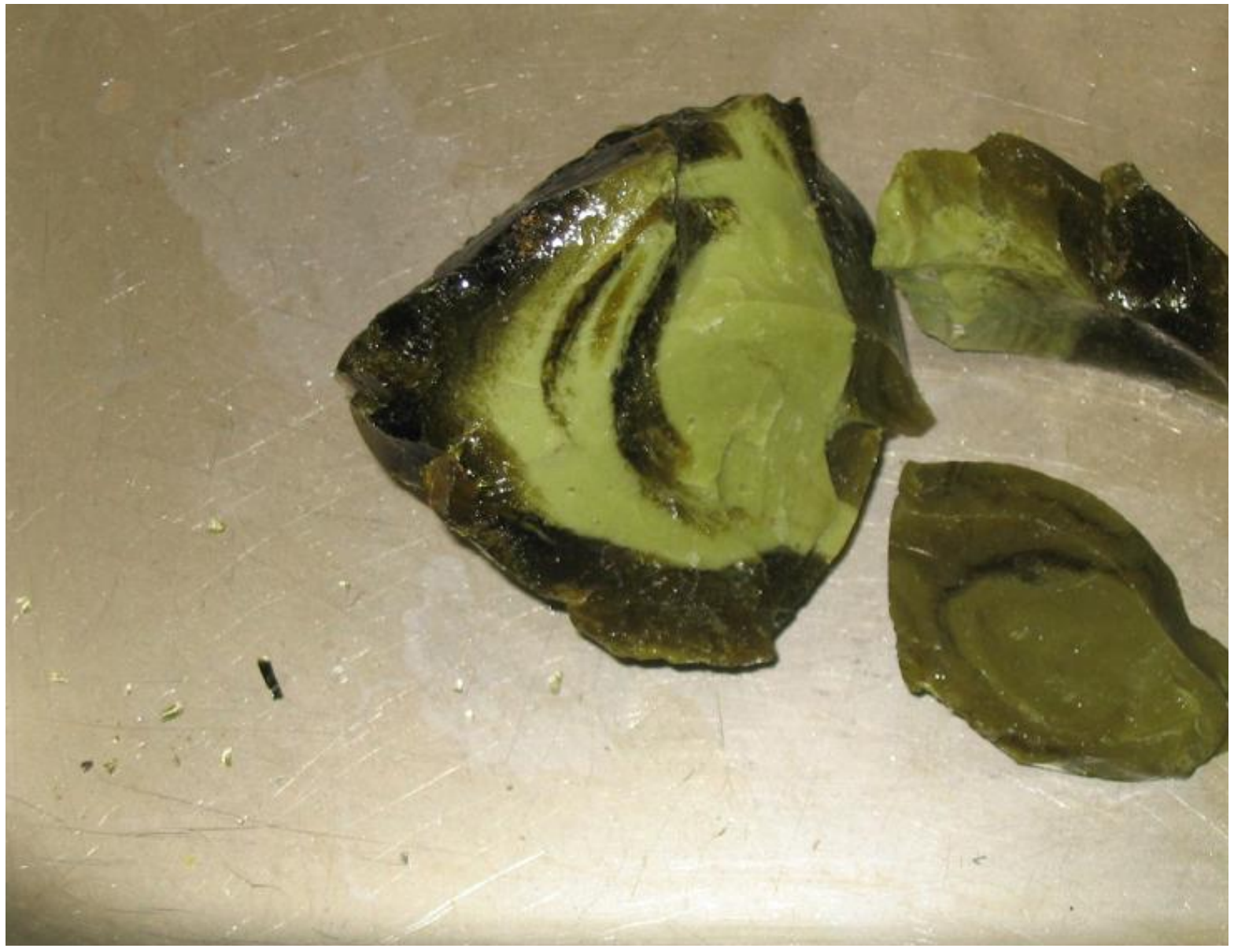

Figure 5.9. Opaque secondary phases in discharged glass (WVY-G-137B, $1.15 \mathrm{wt} \% \mathrm{SO}_{3}$ in feed). 


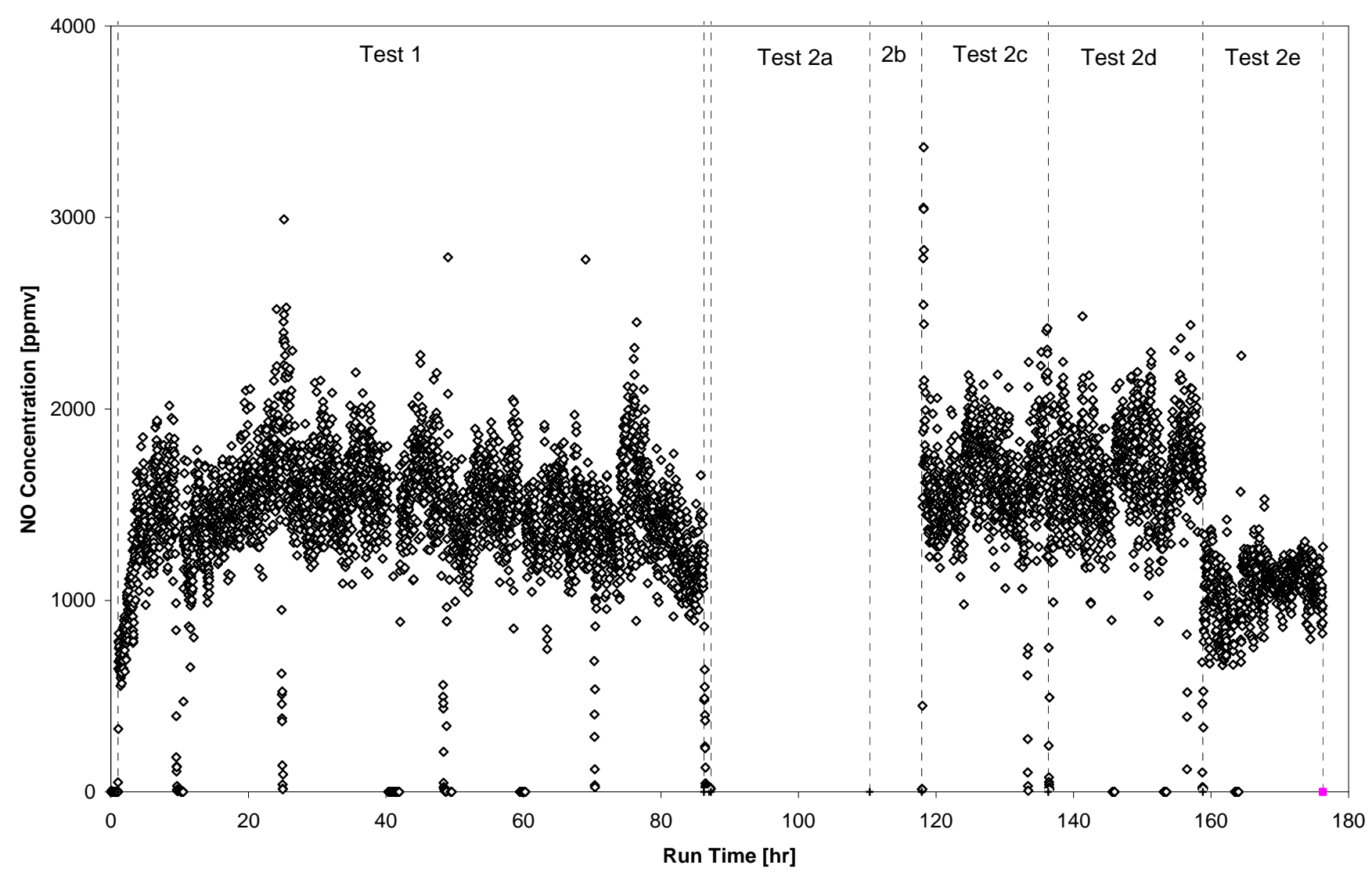

Figure 6.1. Nitrogen oxide concentrations in off-gas from FTIR for the DM100 LAW Envelope C tests. 


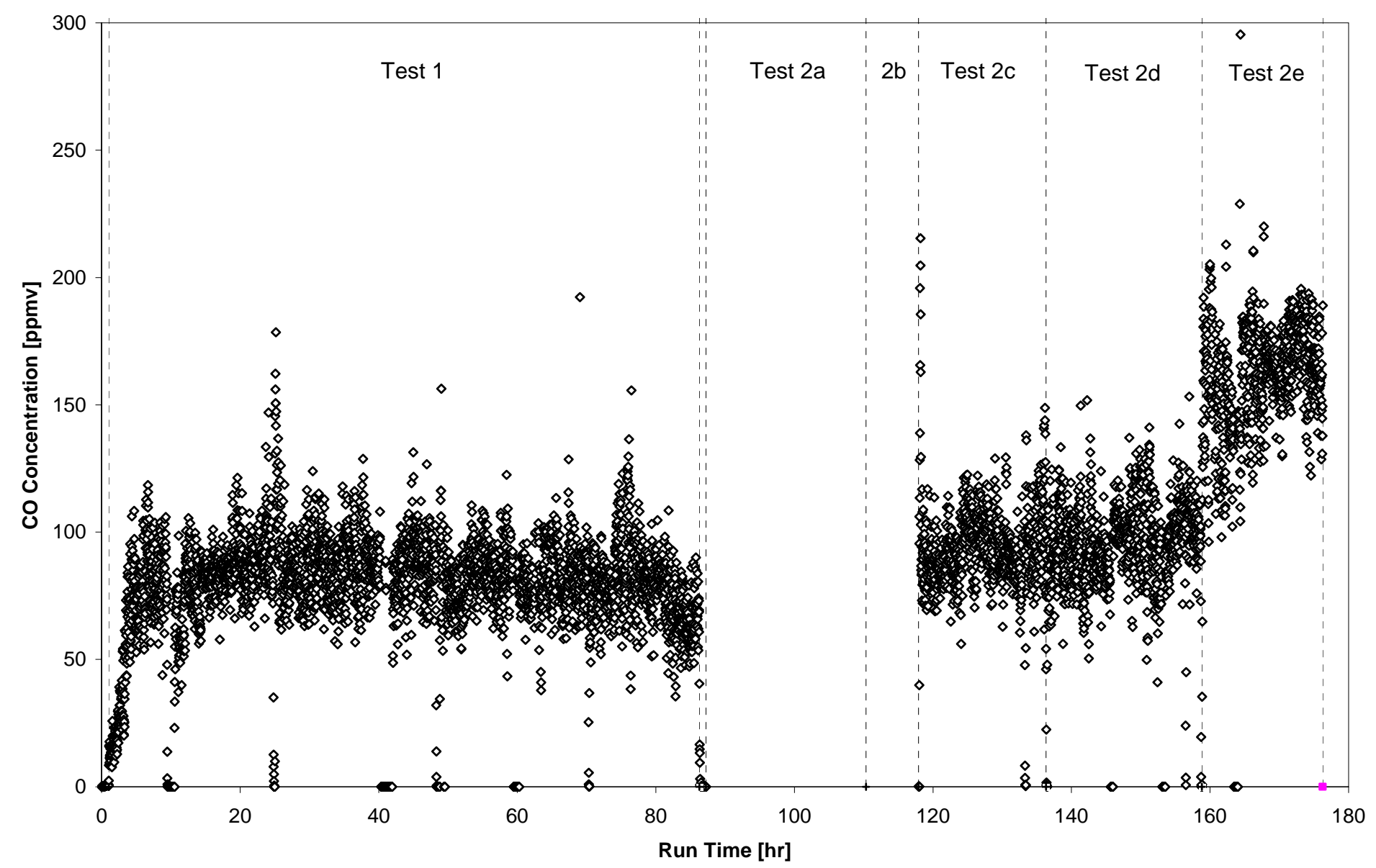

Figure 6.2. CO concentrations in off-gas from FTIR for the DM100 LAW Envelope C tests. 


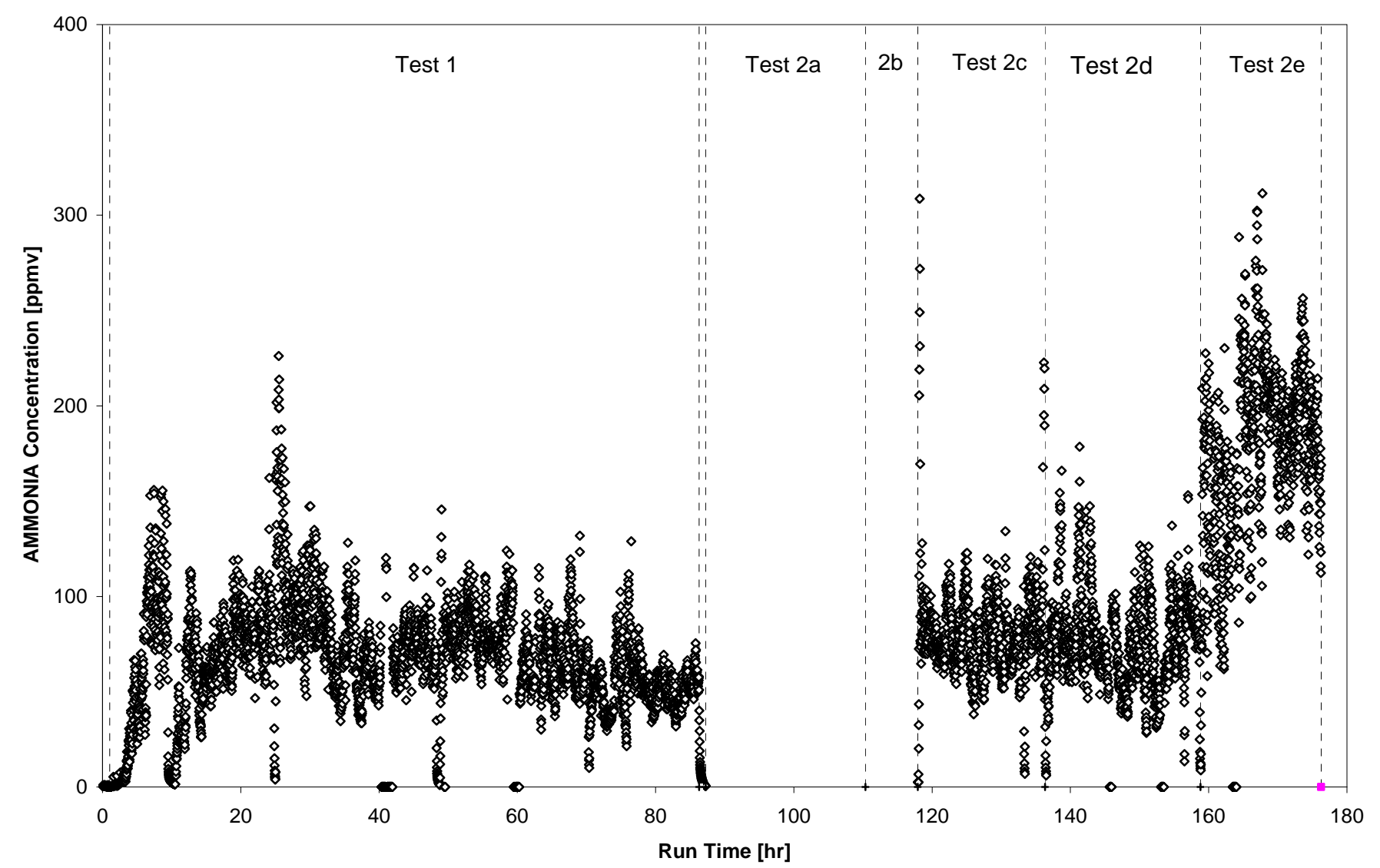

Figure 6.3. $\mathrm{NH}_{3}$ concentrations in off-gas from FTIR for the DM100 LAW Envelope C tests. 